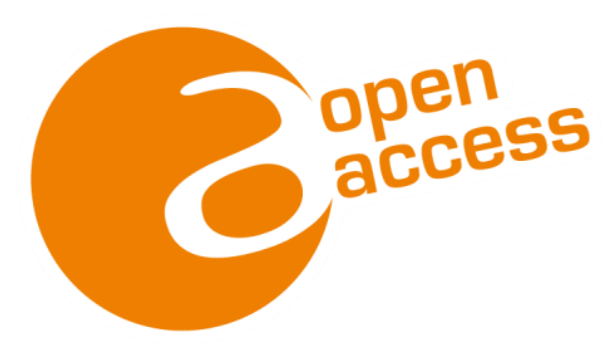

\title{
INFORMATION AND COMMUNICATION TECHNOLOGY (ICT) IN EDUCATION IN FIVE ARAB STATES
}

A comparative analysis of ICT integration and e-readiness in schools in Egypt, Jordan, Oman, Palestine and Qatar

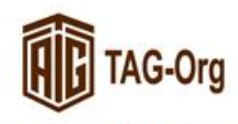

Talal Abu-Ghazaleh Organization

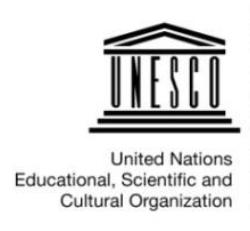




\section{UNESCO}

The constitution of the United Nations Educational, Scientific and Cultural Organization (UNESCO) was adopted by 20 countries at the London Conference in November 1945 and entered into effect on 4 November 1946. The Organization currently has 195 Member States and 9 Associate Members.

The main objective of UNESCO is to contribute to peace and security in the world by promoting collaboration among nations through education, science, culture and communication in order to foster universal respect for justice, the rule of law, and the human rights and fundamental freedoms that are affirmed for the peoples of the world, without distinction of race, sex, language or religion, by the Charter of the United Nations.

To fulfil its mandate, UNESCO performs five principal functions: 1) prospective studies on education, science, culture and communication for tomorrow's world; 2) the advancement, transfer and sharing of knowledge through research, training and teaching activities; 3) standard-setting actions for the preparation and adoption of internal instruments and statutory recommendations; 4) expertise through technical co-operation to Member States for their development policies and projects; and 5) the exchange of specialized information.

UNESCO is headquartered in Paris, France.

\section{UNESCO Institute for Statistics}

The UNESCO Institute for Statistics (UIS) is the statistical office of UNESCO and is the UN depository for global statistics in the fields of education, science and technology, culture and communication.

The UIS was established in 1999. It was created to improve UNESCO's statistical programme and to develop and deliver the timely, accurate and policy-relevant statistics needed in today's increasingly complex and rapidly changing social, political and economic environments.

The UIS is based in Montreal, Canada.

\section{Talal Abu-Ghazaleh Organization}

The Talal Abu-Ghazaleh Organization (TAG-Org) is the largest global organization for professional services and education; providing service in the fields of accounting; external audit; internal audit; corporate governance; taxation; educational consultancy; economic and strategic studies; management advisory services; professional and technical training; technology transfer project management, human resources and recruitment services; e-government; ecommerce; e-education; professional interpretation and translation; website arabization; ICT strategic planning; IPR protection and management and legal services. TAG-Org operates out of 80 offices and 180 representative offices worldwide.

With all the educational advancements this era is witnessing and the $21^{\text {st }}$ century global economy becoming more "knowledge-based", Talal Abu Ghazaleh Educational Consulting (TAG-Education) has taken the initiative and responsibility to support the educational sector with professional consulting services according to the highest standards of excellence by developing dynamic, flexible and quality academic programs which are relevant to the market's needs and requirements.

This report has been produced through joint sponsorship and support of UNESCO, UIS and TAG-Org.

Published in 2013 by:

UNESCO Institute for Statistics

P.O. Box 6128, Succursale Centre-Ville

Montreal, Quebec H3C 3J7

Canada

Tel: $\quad$ (1514) 343-6880

Email: uis.publications@unesco.org

http://www.uis.unesco.org

ISBN 978-92-9189-127-6

Ref: UIS/2013/ICT/TD/01/REV.3, updated in January 2016

\section{CUNESCO-UIS 2013}

The authors are responsible for the choice and presentation of the facts contained in this book and for the opinions expressed therein which are not necessarily those of UNESCO and do not commit the Organization. 


\section{Table of contents}

Page

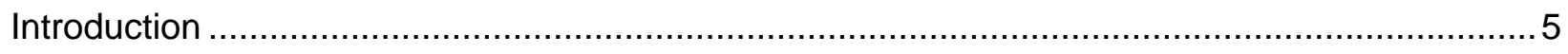

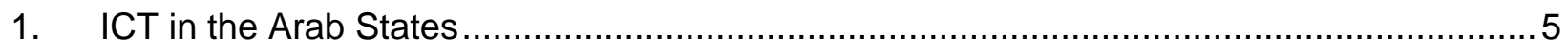

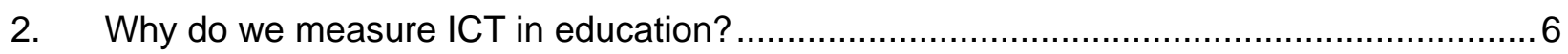

3. Current state of the international framework on ICT in education statistics ..................

4. Methodology: E-readiness as a framework for quantifying ICT in education.......................

5. Integrating ICT in education through policy and other formal commitments...................... 8

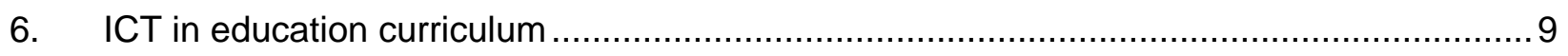

7. Infrastructure to support the integration of ICT in educational institutions ........................11

Electricity and telecommunication facilities................................................................ 11

Building computer and Internet infrastructure: Access to advanced forms of

ICT-assisted instruction ....................................................................................... 12

Allocation of computer resources and overall connectivity ......................................... 14

Types of Internet connectivity in schools .....................................................................18

Computer laboratories, networks and ICT support services ..........................................19

Institutional-level ICT-assisted instruction ...................................................................

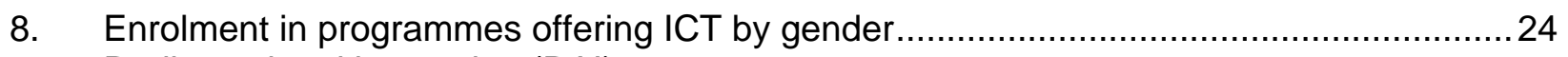

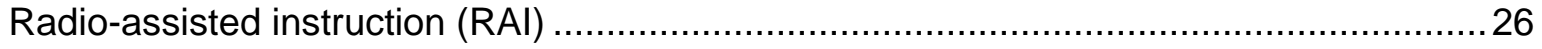

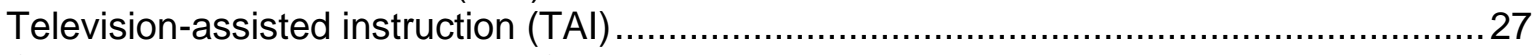

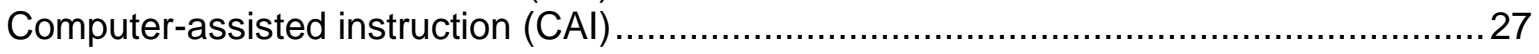

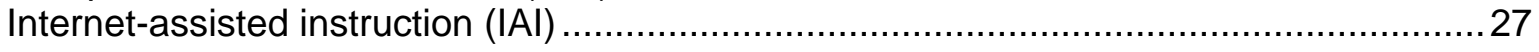

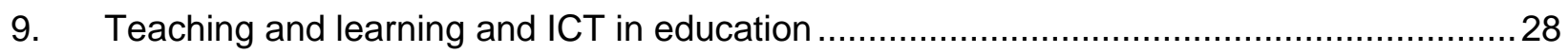

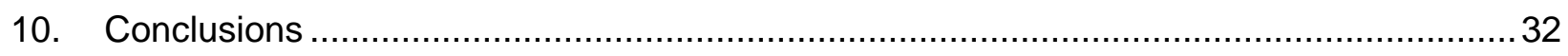

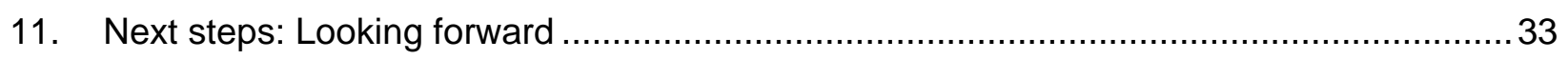

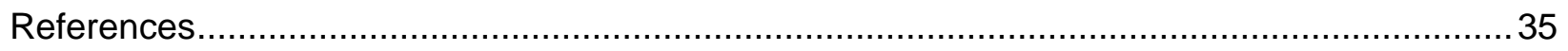

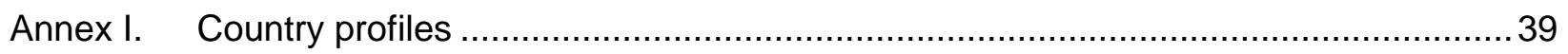

Annex II. Questionnaire on statistics of information and communication technologies (ICT) in education... 


\section{List of boxes}

Box 1. WSIS targets on education and related indicators ........................................................ 6

Box 2. Differences regarding computer/Internet availability in the public and private sectors............17

Box 3. Four types of ICT-assisted instruction ........................................................................... 23

Box 4. ICT usage and learning achievement in mathematics and science: Evidence from the Trends in International Mathematics and Science Study (TIMSS) 2011 ................................ 31

\section{List of text tables}

Table 1. Recommendations for ICT-assisted instruction in national curricula, $2011 \ldots \ldots \ldots \ldots \ldots \ldots \ldots \ldots . \ldots . \ldots . \ldots . \ldots 11$

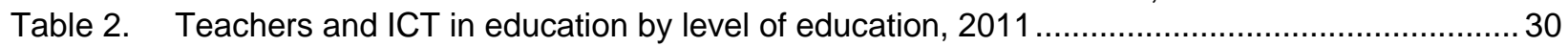

Table 3. Computer usage, activities, and student achievement in mathematics and science among

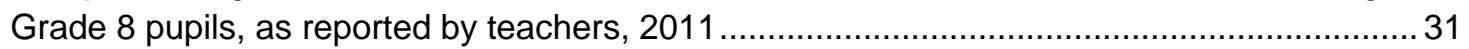

\section{List of figures}

Figure 1. Proportion of educational institutions with basic electrical and telecommunications infrastructure, by level of education, 2011

Figure 2. Learner-to-computer ratio (LCR) and learner-to-computer connected to the Internet ratio (LCCIR), by level of education, 2011.

Figure 3. Computers in educational institutions by allocation and connectivity, by level of education, 2011

Figure 4. Proportion of total computers by allocation and connectivity and in ratio to learners, in primary schools, by sector, 2011

Figure 5. Proportion of educational institutions with Internet connectivity and with broadband connectivity, by level of education, 2011 .18

Figure 6. Computer laboratories, LAN and ICT support services, by level of education, $2011 \ldots \ldots \ldots \ldots . . .20$

Figure 7. ICT-assisted instruction by type and level of education, 2011 .........................................2 23

Figure 8. Participation of pupils in programmes offering ICT-assisted instruction, by gender, $2011 \ldots . .26$ 


\section{Introduction}

More than ever, the advent of the knowledge economy and global economic competition compel governments to prioritise educational quality, lifelong learning and the provision of equal opportunities for all. Education policymakers widely accept that improved access to information and communication technology (ICT) in education can help individuals to compete in a global economy by creating a skilled work force and facilitating social mobility. They emphasise that ICT in education has a multiplier effect throughout the education system, by enhancing learning and providing students with new sets of skills; by reaching students with poor or no access (especially those in rural and remote regions); by facilitating and improving the training of teachers; and by minimising costs associated with the delivery of instruction.

Beyond the rhetoric and of equal if not greater importance to policymakers, are basic questions about the role that ICT plays in basic educational outcomes, including retention and learning achievement. There are those that argue that ICTs are merely a delivery mechanism for teaching and learning, while it is the foundational pedagogy which matters (Clark, 1983; 1994). Others, however, contend that computers and other ICTs may possess properties or affordances that can directly change the nature of teaching and learning (Kozma, 1991; 1994; Dede, 1996). For instance, it is believed that ICT can help to bring abstract concepts to life using images, sounds, movement, animations and simulations. In any case, a better understanding of ICTs and their impact on student outcomes are priorities in all countries, regardless of level of economic development.

\section{ICT in the Arab States}

In the Arab States, national network upgrades, teledensity improvements, enhanced national connectivity, and the gradual introduction of new Internet Provider (IP) delivery technologies are creating a favourable environment for the uptake of ICT. However, much progress remains to be made, and this is truer for some countries more than others. With small populations and high investments in their national networks, some Gulf States have matched international standards in ICT infrastructure, whereas geographically larger countries in the region often remain underserved.

The social movements that arose in 2011 in the Arab States have demonstrated the potential of ICT to play a catalytic role. Arguably, the Arab Spring ranks among the most significant informal ICT-assisted "learning" phenomena in 2011, whereby thousands of youth used social media accessed via their mobile phones - as a space for self-identification, self-assertion, contestation and mobilisation around democracy, human rights and civil liberties (UNESCO, 2012a). The potential for significant change in education and ultimately in society, however, vary within the region. For example, while a number of countries in the Gulf region have achieved relatively high rates of ICT access in schools, the high costs of obtaining communication technology services, the limited number of computers in the education sector, and high levels of technological illiteracy in other countries represent significant barriers to access ICT in education when compared to international rates (Oman, 2011). 


\section{Why do we measure ICT in education?}

For almost four decades, education policymakers have been formalising all-inclusive ICT policies as part of educational renewal and reform. At the international level, policy for integrating ICT for development was first formulated in the Millennium Development Goals (MDGs) Target 8.F, which states that "in cooperation with the private sector, make available the benefits of new technologies, especially information and communications" (United Nations, 2000; United Nations, 2012).

Furthermore, the World Summit on the Information Society (WSIS), held in 2003 and 2005, resulted in a clear commitment by governments to foster the achievement of an inclusive information society. To this end, the WSIS Plan of Action identified ten targets to be achieved by 2015 - two of which are related to education. These include Target 2: Connecting all primary and secondary schools to ICT, which is a precondition to Target 7: Adapting all primary and secondary school curricula to meet the challenges of the information society (Partnership on Measuring ICT for Development, 2011) (see Box 1). The UNESCO Institute for Statistics (UIS) plays a vital role in helping to benchmark country progress within the WSIS framework by collecting statistics and calculating internationally comparable indicators related to ICT in education.

Lastly, while ICT is not mentioned explicitly in the Education for All goals, it is arguable they play a pivotal role in achieving these goals, including broadening access, eliminating exclusion, and improving quality (UNESCO, 2000).

\section{Box 1. WSIS targets on education and related indicators}

Target 2. Connect all secondary schools and primary schools with ICT

1. Proportion of schools with a radio used for educational purposes

2. Proportion of schools with a television used for educational purposes

3. Learner-to-computer ratio

4. Proportion of schools with Internet access, by type of access

Target 7. Adapt all primary and secondary school curricula to meet the challenges of the information society, taking into account national circumstances

1. Proportion of ICT-qualified teachers in schools

2. Proportion of teachers trained to teach subjects using ICT

3. Proportion of schools with computer-assisted instruction (CAI)

4. Proportion of schools with Internet-assisted instruction (IAI)

Source: Partnership on Measuring ICT for Development, 2011

Beyond helping countries benchmark progress, internationally comparable data published by the UIS also play a fundamental role in helping policymakers select priorities and adopt policies related to ICT in education. For instance, policymakers can use UIS data to inform decisions related to: i) national capacity and/or infrastructure levels for integrating new ICT instructional strategies in schools; ii) the types of ICT currently being neglected and/or emphasised; iii) whether or not ICT-assisted strategies are evenly distributed across sectors; iv) whether girls and boys are equally exposed to ICT in education; v) the types of support mechanisms currently in place or the lack thereof; and vi) the relative level of teacher training provided in relation to the demands placed on teachers to teach and/or use ICT in the classroom. 


\section{Current state of the international framework on ICT in education statistics}

Despite the growing demand for ICT in education statistics globally, the most well-known international sources of education statistics lack basic information about ICT policies in education. For developed countries, neither the Organisation for Economic Co-operation and Development (OECD) nor the European Commission have a comprehensive set of indicators that include all three components of inputs, processes, and outcomes related to ICT_although they both are increasingly improving the dataset to include, for instance, assessments of student performance in digital skills. In fact, the OECD's Programme for International Student Assessment (PISA) dataset remains the most reliable source of information on access, use, and outcomes in this domain, despite its limitations in terms of geographical coverage, reliability, and its inadequacy regarding current classroom practices (OECD, 2010; 2011; Scheuermann, Pedró and European Commission, 2009).

For developing countries, the situation is even more challenging. The UIS and UNESCO have recently begun some regional initiatives intended to provide at least a comparative worldwide perspective of access to computers and the Internet in schools, while the World Bank's System Assessment and Benchmarking for Education Results (SABER) initiative and the Inter-American Development Bank are currently focusing on a compilation of detailed information about technology policies in education, mostly from a qualitative perspective. Unfortunately, neither of these initiatives has yet produced a comprehensive global assessment.

\section{Methodology: E-readiness as a framework for quantifying ICT in education}

Considerable strides have been made in the last decade to harness the power of ICT to help meet many development-related challenges, including those related to educational reform and development. Nevertheless, many countries in the Arab States continue to lag behind richer countries to fully implement ICT in their education systems.

The UIS has been tasked with benchmarking and monitoring the integration of and access to ICT in education by establishing internationally comparable and policy-relevant indicators. This project has been coordinated by the UNESCO Communication and Information Sector (CI), in close cooperation with the UIS, and with the support of the UNESCO Education Sector. In March 2012, Cl conducted a data collection using the UIS questionnaire on ICT in education in the Arab States to support the UIS regional survey rollout strategy. The Talal Abu Ghazaleh Organization (TAG.Org) was a key partner in the realization of this report. The UIS was responsible for data analysis and producing the report, in consultation with $\mathrm{Cl}$ and the UNESCO Education Sector.

E-readiness (electronic readiness) is a measure of the degree to which a country is prepared to partake in electronic activities and, thus, benefit from ICT in education (Dada, 2006). Ereadiness may be measured by a number of ICT in education indicators based on data collected in the UIS questionnaire on ICT in education. 
This report assesses ICT integration and e-readiness in education systems of five countries of the Arab States region: Egypt, Jordan, Oman, Palestine ${ }^{1}$ and Qatar. The results will lay the foundation for conducting a fully comprehensive data collection across the entire region and will serve as a basis for comparison and future planning. These indicators can assist with a country's ICT advancement and development efforts by identifying areas where additional efforts are needed. For example, minimum levels of infrastructure are needed before ICTassisted instruction can be implemented. This includes electricity, and in the case of Internetassisted instruction, a basic Internet connection. Moreover, indicators related to teacher preparedness and capacity to instruct effectively using ICT provides more guidance for planning purposes.

The following analysis generally follows a progressive model for the integration of ICT and the essential infrastructure required for its successful implementation. As such, this report starts by examining the policy and curricular aspects of ICT in education as fundamental to building a culture of ICT use in education. This is followed by an analysis of basic infrastructure required to support ICT-assisted instruction, including electrical and Internet connectivity, numbers of computers, and existence of computer laboratories and ICT support mechanisms. The report then reviews institutional capacity for providing programmes aided by different forms of ICT, including radio, television, computers and the Internet, contrasted with enrolment data in such programmes to measure participation rates of both girls and boys in programmes offering ICTassisted instruction. Lastly, the report examines teacher preparedness including relevant training for teaching basic computer skills (or computing) and on how to use ICT in the classroom.

The UIS data collection instrument and this report focus on primary and secondary education. Additionally, Country Profiles are annexed to this report (see Annex I), which summarise all publishable data. The survey instrument used during this data collection is also annexed to this report (see Annex II).

\section{Integrating ICT in education through policy and other formal commitments}

Educational policymakers are in a unique position to bring about change. This is illustrated in a study of 174 ICT-supported innovative classrooms in 28 countries (Kozma, 2003). In 127 cases, there was an explicit connection between the innovation and national policies that promoted the use of ICT (Jones, 2003). But while the introduction of ICT policy is necessary for change, it is not sufficient to result in its implementation or impact (Tyack and Cuban, 1995). Policies can, of course, fail to succeed and this happens when: i) they are viewed as mere symbolic gestures; ii) when teachers actively resist policy-based change that they see as imposed from the outside without their input or participation; iii) when they do not have explicit connections to instructional practice (e.g. focus on hardware rather than their relationship to pedagogy); iv) when they do not provide teachers with an opportunity to learn the policies and their instructional implications; and $v$ ) when there is a lack of programme and resource alignment to the policies' intentions (Cohen and Hill, 2001;Tyack and Cuban, 1995).

1 The data collected from Palestine include the West Bank but not Gaza. Given the different population densities of the two regions, as well as other demographic differences, data published for Palestine are not representative of the current situation regarding ICT in education in Gaza. 
While some policies may fail, identifying those countries that have current active ICT in education policies and/or other types of formal commitments including plans, regulatory provisions or a regulatory institution or body is important for assessing a country's effort to embark on educational reform that implements ICT in education. Data show that all five countries possess each of the aforementioned definitions of formal commitments to ICT in education at primary, lower secondary and upper secondary levels of education. In other words, not only have each of these countries written a policy and plan for the integration of ICT into education, but these countries have also created regulatory provisions and regulatory institutions (or bodies) to ensure that ICT-assisted educational reform takes place and advancement toward established objectives is monitored and evaluated.

While some policies are more successful than others, the case of Jordan has been analysed and discussed widely in international literature as it is recognised both in the Arab States and internationally as a leader in developing its ICT infrastructure and promoting ICT as a tool to improve human capital, foster economic development and reduce poverty (UNESCO, 2011a). Policy documents related to ICT in education have continuously evolved and been systematically updated, including the National Education Strategy (2004) and an overall policy framework for 2007-2011, which was recently updated for 2009-2013 (UNESCO, 2011a). Jordan has systematically set in place a regulatory system through the National Centre for Human Resources Development (NCHRD) to monitor all activities in its reform programme - the Education Reform for the Knowledge Economy (ERfKE) which will be expanded during the next phase scheduled for 2009-2015. This key agency has played an important role in researching ICT applications in basic and secondary education.

In contrast, the implementation of a policy for the use of Open Educational Resources (OER) is lagging behind overall, given that just two out of five countries (i.e. Jordan and Qatar) have declared having national policies for the use of OERs. The term OER was coined at UNESCO's 2002 Forum on Open Courseware and designates "teaching, learning and research materials in any medium, digital or otherwise, that reside in the public domain or have been released under an open license that permits no-cost access, use, adaptation and redistribution by others with no or limited restrictions (OECD, 2007; UNESCO, 2002; 2012b). While OER is typically perceived by many policymakers as an ICT tool that falls within the realm of post-secondary and tertiary levels of education, it will continue to have policy relevance for the development of primary and secondary education as ICT evolves at an exponential rate, both in terms of technological capacity and coverage, becoming more widespread across regions and education levels. However, while policy in the area of OERs is an important precursor for implementation, the Internet requirements of OER can constrain its implementation in a number of countries.

\section{ICT in education curriculum}

In the Arab States, the implementation and use of ICT in education often lags behind other social and economic spheres, including communications, employment and commerce. In fact in many countries in the Arab States, children and youth learn more about how to use various ICT tools informally outside of the school system. The example from Egypt whereby youth efficiently used mobile devices and the Internet to communicate during the Arab Spring is an example of mass usage of ICT that surpasses current capacity within the educational system and schools.

Nevertheless, as the integration of ICT in education rises, and participation and transition rates to higher levels of education increase, children and adults will increasingly need to acquire different forms of digital literacy beyond basic computer skills to participate in several of life's spheres. Learners will need to develop digital literacy, not only for its own sake but also to 
support their education throughout secondary, post-secondary and tertiary levels. The early integration of ICT into primary and secondary curricula through formal recommendations is therefore vital and moreover acts as an important lever for ensuring the introduction and implementation of ICT into educational institutions and classrooms.

Regarding the inclusion of basic computer skills (or computing) in curricula, Jordan, Oman and Qatar state that they have specific objectives or courses at all three levels of primary, lower secondary and upper secondary education. This policy approach is, however, not the case in Egypt and Palestine, where specific objectives or a course covering basic computer skills or computing are lacking in primary education and begin in lower secondary education continuing at the upper secondary level. While many children in Egypt and Palestine may be learning informally how to use ICT, children who are the most disadvantaged economically or geographically will likely continue to be deprived.

In addition to targeted teaching of basic computer skills (or computing), ICT can also be used to teach other subjects to enhance student learning while providing additional learning opportunities about using ICT tools themselves. National policies and plans may be very explicit about recommendations for ICT-assisted instruction focusing only on certain subjects and/or at certain levels, while other countries may have a more generalised and comprehensive set of recommendations for ICT-assisted instruction to be implemented across the entire national curriculum at all levels of education. Oman, a country that extends the use of ICT in all areas of the curriculum and at all levels, states in its education policy that since meaningful learning takes place within contexts in which students are familiar, it is vital that learning experiences associated with ICT should not be isolated from other studies, but rather, the knowledge, skills and values associated with computer use need to be integrated into all subject areas (Oman, 2008).

The inclusion of recommendations for ICT-assisted instruction in the national curriculum of countries participating in this study appears to be relatively diverse ranging from heavily integrated across subjects in Jordan, Oman and Qatar to relatively infrequent use in Egypt where recommendations specifically target only specific subjects at certain levels. For example, Table 1 shows that Jordan and Qatar include recommendations to use ICT in all subjects for every grade in primary through to upper secondary education (Jordan, 2011; McKinsey and Company, 2005).

Focusing on the integration of e-content and e-learning practices into several subject areas, Jordan's Education Initiative (JEI) has been a source of innovation in extending ICT across the curriculum for all grade levels (i.e. Grades 1 to 12) (UNESCO, 2011a). The JEI used 100 public schools (called "Discovery Schools") where JEl products were piloted prior to a national launch by the Ministry of Education. Of equal importance for ICT integration, in 2004 the ministry issued a Curriculum and Learning Assessment Framework, which guided the rewriting of curricula in all subjects for all grades between 2004 and 2008. Alongside the JEI, this framework provided the basis for the development of a broad programme of e-learning content which is now in full application and on-going development.

In contrast to countries where ICT usage is heavily spread across curricula, recommendations for the use of ICT in Egypt are scattered across subjects and levels of education. Egypt provides recommendations for use of ICT in at least one grade in the sciences at all levels of education and at least one grade in second languages for lower and upper secondary education. 
Meanwhile, Palestine lies between these two groups of countries. The country has recommendations to use ICT in all grades at all levels for the acquisition of second languages. There are also recommendations for at least one grade at all levels of education in mathematics, sciences, written communication (languages) and arts.

Table 1. Recommendations for ICT-assisted instruction in national curricula, 2011

\begin{tabular}{|c|c|c|c|c|c|c|c|c|c|c|c|}
\hline & & \multicolumn{2}{|c|}{ Mathematics } & \multicolumn{2}{|c|}{ Sciences } & \multicolumn{2}{|c|}{$\begin{array}{c}\text { Written } \\
\text { Communication } \\
\text { (Languages) }\end{array}$} & \multicolumn{2}{|c|}{ Second Languages } & \multicolumn{2}{|c|}{ Arts } \\
\hline & & $\begin{array}{l}\text { Every } \\
\text { grade }\end{array}$ & $\begin{array}{c}\text { At least } \\
\text { one grade }\end{array}$ & $\begin{array}{l}\text { Every } \\
\text { grade }\end{array}$ & $\begin{array}{c}\text { At least } \\
\text { one grade }\end{array}$ & $\begin{array}{l}\text { Every } \\
\text { grade }\end{array}$ & $\begin{array}{c}\text { At least } \\
\text { one grade }\end{array}$ & $\begin{array}{l}\text { Every } \\
\text { grade }\end{array}$ & $\begin{array}{c}\text { At least } \\
\text { one grade }\end{array}$ & $\begin{array}{l}\text { Every } \\
\text { grade }\end{array}$ & $\begin{array}{c}\text { At least } \\
\text { one grade }\end{array}$ \\
\hline \multirow{3}{*}{ Egypt } & Primary & & & & $\mathrm{V}$ & & & & & & \\
\hline & Lower secondary & & & & $v$ & & & & $\mathrm{v}$ & & \\
\hline & Upper secondary & & & & $v$ & & & & $v$ & & \\
\hline \multirow{3}{*}{ Jordan } & Primary & $v$ & & $v$ & & $v$ & & $\sqrt{ }$ & & 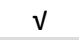 & \\
\hline & Lower secondary & $v$ & & $v$ & & $\checkmark$ & & v & & v & \\
\hline & Upper secondary & $v$ & & v & & v & & v & & $v$ & \\
\hline \multirow{3}{*}{ Oman } & Primary & 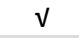 & & v & & $v$ & & v & & & v \\
\hline & Lower secondary & $v$ & & $v$ & & $v$ & & v & & & v \\
\hline & Upper secondary & $v$ & & $v$ & & $\mathrm{v}$ & & $\mathrm{v}$ & & & $\mathrm{v}$ \\
\hline \multirow{3}{*}{ Palestine } & Primary & & v & & v & & v & 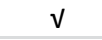 & & & v \\
\hline & Lower secondary & & v & & $\sqrt{ }$ & & v & $\sqrt{ }$ & & & v \\
\hline & Upper secondary & & $v$ & & v & & v & $\sqrt{ }$ & & & v \\
\hline \multirow{3}{*}{ Qatar } & Primary & $v$ & & $\mathrm{v}$ & & v & & v & & v & \\
\hline & Lower secondary & $\checkmark$ & & v & & v & & $\checkmark$ & & v & \\
\hline & Upper secondary & $\mathrm{v}$ & & $\mathrm{v}$ & & $\mathrm{v}$ & & $\mathrm{v}$ & & $\mathrm{v}$ & \\
\hline
\end{tabular}

Notes: Data for Egypt reflect the academic year ending in 2010. Data for Palestine reflect the academic year ending in 2012. Data for Palestine reflect only the West Bank.

Source: UIS database.

\section{Infrastructure to support the integration of ICT in educational institutions}

\section{Electricity and telecommunication facilities}

To support teaching and learning processes, as well as to improve overall education management, a variety of ICT-assisted instructional approaches have been implemented over the years, ranging from the use of radio or television to computers, Internet and other technologies. However, whatever the combination, the integration of ICT into schools requires electricity (e.g. grid/main connection, wind, water, solar or fuel-powered generator, etc.) that is regularly and readily available. While this is not always strictly the case for radio, which can be operated using batteries, television, computers and the Internet require a much more stable energy source.

Nonetheless, alternative forms of ICT are currently being introduced to several developing countries with less than adequate electrical infrastructure. For example, the rugged, low-cost XO computers - which are purchased from One Laptop per Child (OLPC) by national governments - use significantly less electricity than standard laptops relying on an array of batteries, solar power panels and human-powered generators to function. Palestine has been a significant participant in the XO project, deploying 4,000 computers in the West Bank and 6,000 in Gaza. Through networking and fundraising, OLPC intends to eventually provide a laptop to all children in Palestine and in schools operated by the United Nations Relief and Works Agency in the Middle East (OLPC, 2013). 
In order to gauge national commitment to ICT in education, measuring the share of schools with electricity and a telephone communication facility (defined as a fixed telephone line, cable connection, mobile phone or other sustainable communication technology that connects a school's terminal equipment (e.g. telephone set or facsimile machine) to the public switched telephone network and which is intended for pedagogical or administrative purposes) provides information on institutional capacity.

According to Figure 1, electricity is almost universally available in primary and secondary schools in Egypt, Jordan, Oman and Palestine, and in every school in Qatar. This suggests that the basic electrical infrastructure is generally in place to integrate ICT in the classroom; where ICT is lacking, it is not necessarily attributable to the absence of a power supply.

The existence of telecommunication facilities in schools is slightly less frequent. While the majority of schools have a facility in both Oman and Palestine, shares are lower in Egypt and Jordan, which have large rural areas. In Jordan, for example, $73 \%$ of primary educational institutions have a telephone communication facility - increasing to $81 \%$ and $89 \%$ in lower and upper secondary educational institutions, respectively. The share of primary schools in Egypt with a telephone communication facility $(70 \%)$ is similar to that of Jordan; however, in Egypt the share decreases at the secondary level of education, with $68 \%$ and $66 \%$ of lower and upper secondary educational institutions, respectively, having the infrastructure. In Qatar, all primary and secondary educational institutions have a telephone communication facility.

Figure 1. Proportion of educational institutions with basic electrical and telecommunications infrastructure by level of education, 2011

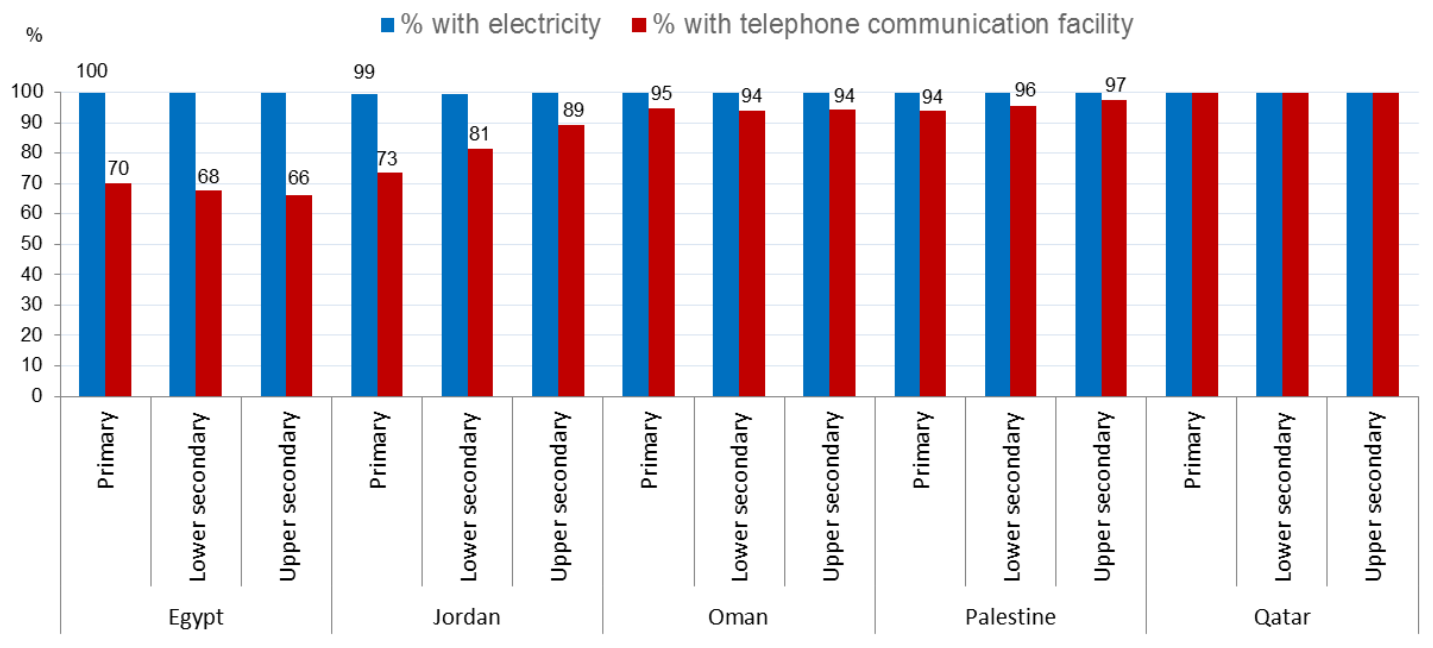

Notes: Data for Egypt reflect the academic year ending in 2010. Data for Palestine reflect the academic year ending in 2012. Data for Palestine reflect only the West Bank.

Source: UIS database. 


\section{Building computer and Internet infrastructure: Access to advanced forms of ICT-assisted instruction}

In order for countries to provide advanced forms of ICT-assisted instruction, including the use of computers and the Internet, adequate resources must be established, keeping pace with demand based on enrolment. The learner-to-computer ratio (LCR) refers to the average number of learners per computer available for pedagogical use and measures the national level of computer access in aggregate education systems. While there is no international target, a high LCR indicates substantially less computer access per learner than a low LCR, since more students are required to share the same computer.

The LCR sheds light on current infrastructure to support the integration of ICT-assisted instruction. It, however, does not provide information on the range of LCRs across regions, schools, or educational sector (see Box 2). For instance, while the LCR may be low in some regions (e.g. urban centres) indicating greater access, it may be much higher in others (e.g. rural and remote areas) indicating scarce resources and minimal access. In Jordan, for example, schools falling under the authority of the United Nations Relief and Works Agency (UNRWA) for Palestine refugees have an LCR of 29:1, compared to the national average of 17:1 (Jordan, 2012).

The LCR also does not take into account the issue of computer obsolescence. For instance, several computers may be outdated or in disrepair. It also does not take into account whether or not computers are even in use. There are cases where newly purchased computers remain in boxes and are not distributed among classrooms or laboratories for pupils to use even though they are captured in national statistics.

While the LCR indicator does not provide information on computer usage, it may be considered as a proxy measure for enabling computer usage since there is a relationship between LCR and individual learner time using a computer. In most schools, there is typically more than a 1:1 ratio between learner and computer, whereby more than one student must share a single computer. Sometimes there are only a small number of learners sharing a computer in school, and group work using computers can have some learning benefit - especially if based on a collaborative or cooperative learning model. In other schools, however, the number of learners sharing a computer is so high that time on task is too limited per learner to allow a meaningful learning experience.

While schools need to acquire computers given the ever-increasing reliance on ICT in several life spheres, the push towards two-way communications between individuals over long distances necessitates computers that are connected to the Internet. The learner-to-computer connected to the Internet ratio (LCCIR) is an indicator that measures the capacity of education systems to support ICT-assisted instruction that uses the World Wide Web.

Figure 2 shows the LCRs and LCCIRs for primary, lower secondary and upper secondary education levels. In Egypt, for instance, data show that available computer resources are greatly overstretched since, on average, 120 primary-level pupils nationwide share a single computer ${ }^{2}$. On the other hand, given the lack of recommendations for integrating ICT across the entire primary education curriculum in Palestine, an LCR of 38:1 may not necessarily represent a situation where computer resources are overstretched. In Jordan and Oman, where there are

2 However, significant inter-school and inter-regional differences exist. 
recommendations for integrating ICT in all grades and most subjects, there are 26 and 20 primary-level learners, respectively, per computer. In almost all cases, the LCR decreases from primary to secondary levels of education indicating greater access at higher levels. Qatar also has recommendations for using ICT in all grades and subjects and has a primary LCR of 14:1; however, this is unevenly distributed between public and private sectors (see Box 2).

\section{Figure 2. Learner-to-computer ratio (LCR) and learner-to-computer connected to the Internet ratio (LCCIR) by level of education, 2011}
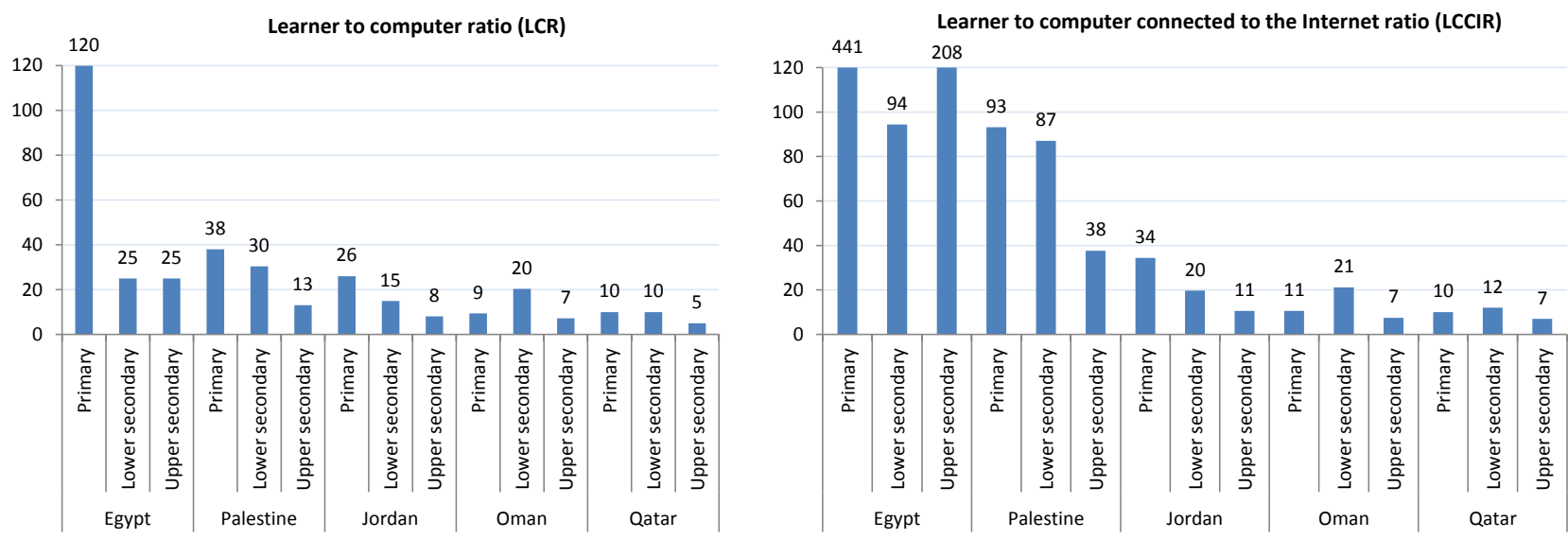

Notes: Data for Egypt reflect the academic year ending in 2010. Data for Palestine reflect the academic year ending in 2012. Data for Palestine reflect only the West Bank.

The LCCIR is calculated based on all computers, which may include those used for administrative purposes. As such, learner access to the Internet may be somewhat inflated as represented in the LCCIR values shown in Figure 2. These values should be considered as UIS estimates.

Source: UIS database.

Among the countries with greater access to computers (e.g. Jordan, Oman and Qatar), the LCCIR is not substantially higher than the LCR. For example, while LCRs are 9:1, 20:1 and 7:1 in Oman for primary, lower secondary and upper secondary education, respectively, LCCIRs are only slightly higher at $11: 1,21: 1$ and $7: 1$. In other words, countries with higher levels of computer access are also more likely to have higher levels of Internet connectivity.

In countries where general access to computers is already a challenge, there is a disproportionate shortage of Internet connectivity. In Palestine, primary and lower secondary LCCIRs are more than twice as high - 93:1 and 87:1, respectively - than LCRs of 38:1 and $30: 1$. At the upper secondary level, the LCCIR (38:1) is almost three times higher than the LCR $(13: 1)$.

In Egypt, there are no specific recommendations for a course in basic computer skills at the primary level and ICT tools are poorly integrated in most areas of the curriculum. In addition to the lack of curricular recommendations, poor Internet infrastructure exists where 441 primarylevel students on average share a single computer connected to the Internet. Access improves somewhat at the lower secondary level where 94 students share a computer connected to the Internet, but this remains almost four times less than the number of students who have access to a computer in general (i.e. LCR of 25:1). 


\section{Allocation of computer resources and overall connectivity}

Building infrastructure to support newer forms of ICT-assisted instruction using computers and the Internet requires substantial resources. To ensure that students have access, schools need to maintain adequate numbers of computers, keeping pace with student enrolment and technological change, and ensure that policies support the allocation of sufficient numbers of computers for pedagogical purposes, ensuring Internet connectivity.

Countries provide data on total computers within the education system, including those allocated to learners, teachers, administrative staff, or some combination of these. It is important to report the number of computers allocated to pedagogical purposes in order to have an accurate picture of the general level of access to support learning and teaching. An understanding of computer allocation strategy is also important, since it provides insight into possible redistribution of computers. For instance, in countries where computers are scarce and a high proportion is used for administrative purposes, a redistribution strategy may lead to more equitable sharing among students and/or teachers.

Figure 3 sheds light on the allocation strategy for computers, as well as their associated connectivity level in primary and secondary schools. Egypt, where computer resources are greatly overstretched and there are 120 primary-level pupils on average sharing a single computer, allocates the largest proportion of its computers to pedagogical purposes in primary $(91 \%)$, lower secondary (96\%) and upper secondary (96\%) education. However, while Egypt allocates the largest share of its computers to learning, the largely rural country has a low share of computers (regardless of allocation) connected to the Internet, where respectively $25 \%, 25 \%$ and $11 \%$ of computers at the primary, lower secondary and upper secondary level are connected. In sum, Egypt is constrained in its efforts to spread a culture of ICT-assisted instruction by a basic lack of devices and Internet connectivity.

Figure 3. Computers in educational institutions by allocation and connectivity, by level of education, 2011

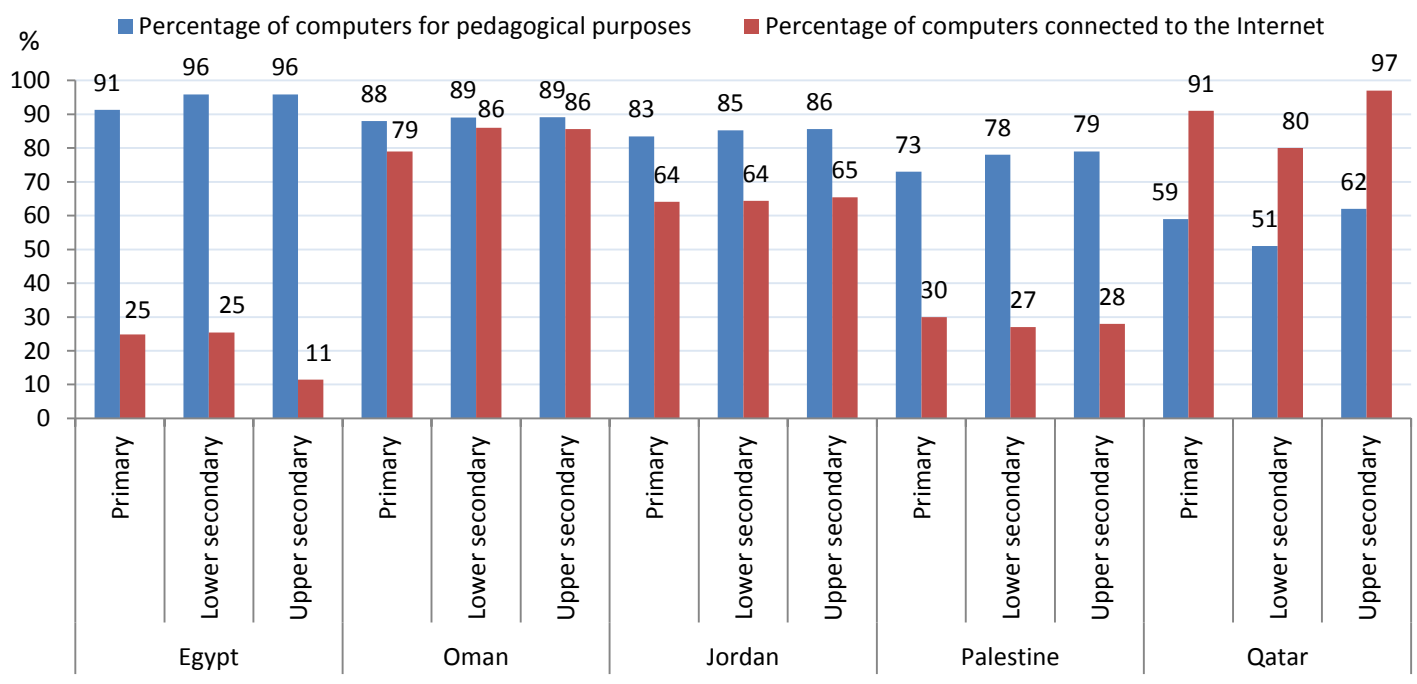

Notes: Figures representing the percentage of computers connected to the Internet include all computers including those used pedagogically and administratively. Therefore, the actual proportion of computers connected to the Internet available for pedagogical purposes may be lower than the figures presented above.

Data for Egypt reflect the academic year ending in 2010. Data for Palestine reflect the academic year ending in 2012. Data for Palestine reflect only the West Bank.

Source: UIS database. 
Jordan and Oman also allocate a sizeable majority of computers (i.e. approximately threequarters or more) to pedagogical purposes for all levels of education. Given the lower LCRs and LCCIRs for these two countries, this "balanced" allocation strategy takes into consideration the need for ICT for administrative purposes as well as for pedagogy. In fact, Jordan addresses the allocation of ICT for both pedagogical and administrative purposes in its policy framework by focusing on cost-efficient measures to acquire resources, rather than solely relying on increases to the education budget (UNESCO, 2011a). In addition to allocating the majority of its computers to pedagogical purposes, Oman possesses relatively high capacity levels to support advanced ICT-assisted instruction using both computers and the Internet, given that about $80 \%$ or more of computers are also connected to the Internet.

The availability of computers and especially computers connected to the Internet is also overstretched in Palestine given the relatively high national level LCR and LCCIR. However, Palestine, unlike Egypt, practices a more balanced approach in the allocation of computers and connectivity to both administration and pedagogy. Nevertheless, given that approximately onequarter of computers are used for non-pedagogical purposes, new sharing systems or reallocation of some computers to instruction could be re-examined.

Also in Figure 3, Qatar provides data suggesting that a low share of computers is actually allocated to pedagogy - about $59 \%, 51 \%$ and $62 \%$ for primary, lower secondary and upper secondary, respectively. However, this may not represent an obstacle to access in terms of computers in this country, given the relatively lower national-level LCR (see Box 2). Access to the Internet is somewhat uneven in schools in Qatar, which can be attributed to educational sector whereby public schools are much more likely to be connected (see Figure 5).

\section{Box 2. Differences regarding computer/Internet availability in the public and private sectors}

The availability of ICT resources is often impacted by the source of funding for educational institutions. For instance, while some private institutions exist to provide alternative educational opportunities to the public sector - frequently of higher quality or meeting religious criteria - others are established to fill gaps left by national education authorities (e.g. in remote regions and funded by communities and parents). As a result, the infrastructure available-not to mention quality-may vary significantly between public and private institutions.

Figure 4 presents the percentage of computers used for pedagogical purposes, the percentage of computers connected to the Internet, as well as the learner-to-computer ratio (LCR) and learner-tocomputer connected to the Internet ratio (LCCIR) in primary education disaggregated by sector. Data show that in Egypt, Jordan, and Oman a higher share of computers are allocated to pedagogical purposes in the public sector than in the private sector - albeit more than 80 per cent are allocated to pedagogy in both sectors. In contrast more than 80 per cent of computers are allocated to pedagogy in private schools in Palestine and Qatar but in public schools, the proportion decreases to 65 per cent and 57 per cent, respectively.

Taking enrolment data into consideration, these trends impact learners' computer access level differently-as measured by the learner-to-computer ratio (LCR). For example, Figure 4 shows access to computers is lower in public schools in Egypt and Palestine given that 151 and 60 primary-level pupils share a single computer, respectively, compared to 37 and 19 pupils in private education. In contrast, access to computers in Qatar is substantially greater in public schools (5:1) than in private schools (55:1), while in Jordan and Oman, sector has negligible impact.

According to Figure 4, education sector also relates to Internet availability - albeit again differently. In Egypt, Jordan and Palestine, computers in public schools are less likely to be connected than in private schools. In Egypt and Palestine, for example, the proportion connected approximately doubled from 20 per cent and 19 per cent in public schools to 38 per cent and 42 per cent, respectively. In contrast, $87 \%$ of computers are connected to the Internet in public primary education institutions in Oman, while one-third (33\%) are connected in the small private sector of 
Oman, which is mostly located in rural areas. Finally, given connectivity challenges in Qatar's private sector primary educational institutions, the proportion of the computers connected to the Internet is 24 per cent compared to 100 per cent in the public sector.

\section{Figure 4. Proportion of total computers by allocation and connectivity and in ratio to learners, in primary schools, by sector, 2011}
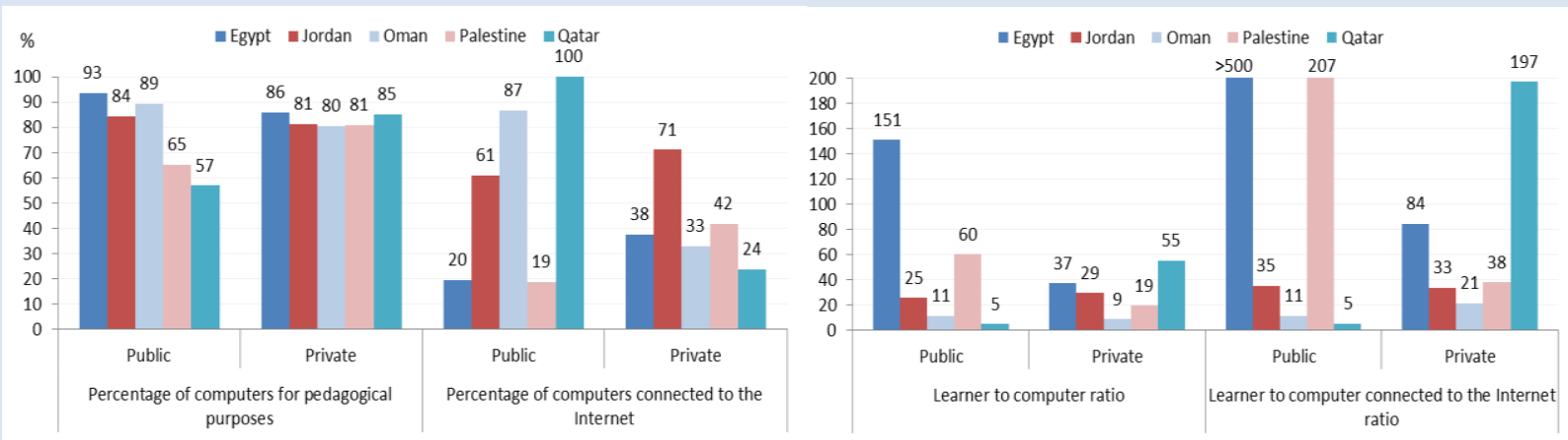

Notes: The share of public enrolment as a percentage of total enrolment is as follows: Egypt (92\%), Jordan (74\%), Oman (94\%), Palestine (80\%) and Qatar (43\%). Data are aggregated for total public versus private sectors and therefore may mask substantial differences within the actual range of values representing individual public and/ or private educational institutions. Data for Egypt reflect the academic year ending in 2010. Data for Palestine reflect the academic year ending in 2012. The LCCIR is calculated based on all computers, which may include those used for administrative purposes. As such, learner access to the Internet may be somewhat inflated as represented in the LCCIR values shown. LCCIR values should be considered as UIS estimates. Total values for Qatar also represent UIS estimates.

Source: UIS database.

Taking enrolment data into consideration, trends also impact learners' access to the Internet differently as measured by the learner-to-computer connected to the Internet ratio (OCIIR). Given the lack of Internet connectivity in Egypt and Palestine, LCIIRs are relatively high. For example in Egypt, where ICT tools are not integrated into primary-level curricula, pupils in primary private institutions are about nine times (84:1) more likely to have access to a computer connected to the Internet than a pupil in the public system (719:1). In Palestine, 207 pupils in public institutions share a single computer connected to the Internet at the primary level, compared to 38 in the private sector.

In the small Gulf country of Qatar, where there are recommendations for using ICT in all grades and subjects, the type of school is also a significant predictor of access to computers and the Internet. While there are only 5 children sharing a computer with Internet access in public primary schools, there are 197 primary students sharing a computer connected to the Internet in private schools. Based on the analysis, policies that better incorporate sector differences in access to computers and the Internet, taking into consideration regional differences related to infrastructure are needed to ensure more children can access ICT in education.

\section{Types of Internet connectivity in schools}

Given that connectivity is a prerequisite for the integration of ICT-assisted instruction using the Internet, an analysis of basic Internet connectivity is primordial in determining a country's level of preparedness. Increasingly, the need for broadband connectivity and high bandwidth are necessary to effectively support instruction over the Internet, particularly for two-way synchronous communication (e.g. video conferencing), streaming videos, and using online applications and databases that have high capacity requirements (Broadband Commission, 2013). Nevertheless, furnishing narrowband Internet in certain contexts might be considered as a temporary solution to fill in gaps experienced by institutions that would otherwise be unconnected. Remote and rural regions are typically most disadvantaged in the establishment of any type of supporting infrastructure to support Internet connectivity. 
Figure 5 shows the proportion of primary and secondary educational institutions with any type of Internet connection, as well as those with a fixed broadband connection. Less than one-half of educational institutions in Palestine and Egypt have an Internet connection, while more than two-thirds of all educational institutions in Oman and Jordan are connected. In general, secondary educational institutions are given priority, and this is most evident in the case of Oman, where $71 \%$, of primary schools are connected compared to $87 \%$ of lower secondary and upper secondary schools, respectively ${ }^{3}$.

Figure 5. Proportion of educational institutions with Internet connectivity and with broadband connectivity by level of education, 2011

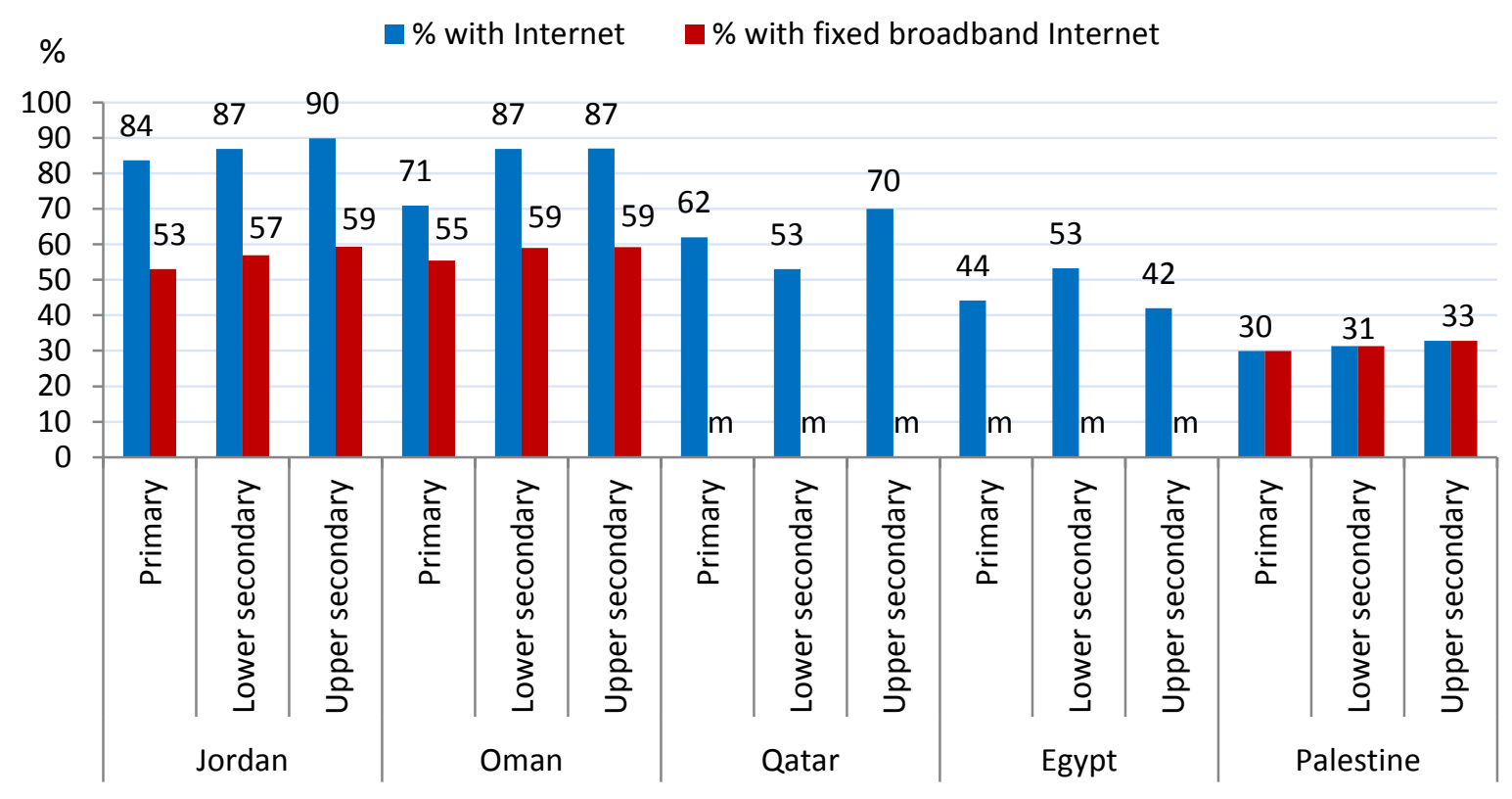

Notes: $m=$ missing data.

Data for Egypt reflect the academic year ending in 2010. Data for Palestine reflect the academic year ending in 2012. Data for Palestine reflect only the West Bank.

Source: UIS database.

In Qatar, where resources are unevenly distributed between the public and private sectors, $62 \%$, $53 \%$ and $70 \%$ of total primary, lower and upper secondary schools, respectively, are connected to the Internet ${ }^{4}$ (see Box 2).

Fixed broadband connectivity presents a challenge for many countries in the region. However, in Palestine, where about one third of schools have Internet connections, all are via fixed broadband. In Oman and Jordan, where different types of connections coexist, more than onehalf of Internet connections are via broadband. Data on fixed broadband Internet are not available for Egypt and Qatar. Similar to the Internet in general, the implementation of fixed broadband connectivity is prioritised for secondary institutions in both Jordan and Oman, rising incrementally by level of education.

3 From a logistical perspective, most countries have fewer secondary level institutions, which may facilitate connecting all secondary schools before primary level institutions can also be connected.

4 In Qatar, all (100\%) public educational institutions are connected to the Internet. 


\section{Computer laboratories, networks and ICT support services}

The installation of computer laboratories in schools is a significant upgrade to where a class might have one desktop computer in the back of the room. More recently, however, given the reality of a multitude of both personal and school-owned devices (including laptops, tablets and mobile devices), education technologists argue that computer laboratories are becoming obsolete and may, in fact, provide a disservice in some situations, since they imply that computing is a separate subject and that the use of ICT ought not to be fully integrated into the general curriculum. Others point to an inadequate budget in most schools for one-to-one programmes and that more computer skills classes should be developed, in addition to integrating technology into the rest of the curriculum (Pedro, 2012; UNESCO, 2011a).

While the promotion of One Laptop per Child programmes has as its aim the achievement of learner-to-computer ratios of $1: 1$, few countries have been able to attain this. Alternative strategies may potentially improve the availability and management of ICT-assisted instruction in schools. For instance, one alternative is the use of multi-seat computers or networked PCs, where users simultaneously operating from a single CPU and server possess their own individual monitors and keyboards.

As long as ratios of learner-to-devices and the Internet are more than 1:1, computer laboratories may help to fill in this gap by playing an important role in managing and organising how and when children are subject to ICT-assisted instruction. In the past, many have suggested that computer laboratories can facilitate the teachers' role in structuring learning opportunities more efficiently for a large number of children around computers than having fewer computers in individual classrooms. For this reason, computer laboratories - in addition to classroom-based individualised learning - can effectively support ICT-assisted instruction.

Local Area Networks (LANs), which refer to a network connecting computers within a localised area such as a single building, department or site, also expand potential for ICT-assisted instruction by emphasising interactivity and communication between pupils and/or teachers. They provide the following benefits to learning and teaching: i) increasing resource sharing; ii) flexibility in that information can be accessed from a number of locations in the school setting; iii) network licensing is cheaper than for individual devices allowing for access to a wider segment of children and incurring substantial savings; iv) quick and easy file sharing; v) additional security to computers and information via a central backup and safety system; and vi) devices can be shared by a number of users (including printers, scanners, etc.).

While computer laboratories and LANs can help expand technological capacity, ICT support services are increasingly important in a highly technical environment. ICT support services must ensure the sustainability of ICT facilities (e.g. computer laboratories and LANs), and they are vital in the coordination, maintenance and overall viability of ICT facilities. More specifically, ICT support services typically coordinate the effective use of ICT across the curriculum for both students and teachers to ensure that teachers and students alike understand how to effectively use ICT in their work. Secondly, they monitor how equipment and software are accommodated, acquired, maintained and replaced. Without ICT support services, several challenges may arise, including the possibility that ICT equipment falls into disrepair, is not properly maintained and replaced, leading to obsolescence.

Figure 6 demonstrates varying degrees of ICT infrastructure within countries to support and enhance the provision of ICT-assisted instruction. In Egypt, for example, where national policy has been to provide computer laboratories in schools at the rate of one laboratory per every 15 
classes (Hamdy, 2007), computer laboratories are relatively scarce in primary (12\%), lower secondary (42\%), and upper secondary (23\%) educational institutions, respectively. In Palestine, which does not integrate the use of ICT into all grades of primary education, computer laboratories are available in only $55 \%$ of primary institutions, compared to $71 \%$ in lower secondary and $87 \%$ in upper secondary institutions where ICT is more heavily integrated into the national curriculum.

\section{Figure 6. Computer laboratories, LAN and ICT support services by level of education,} 2011

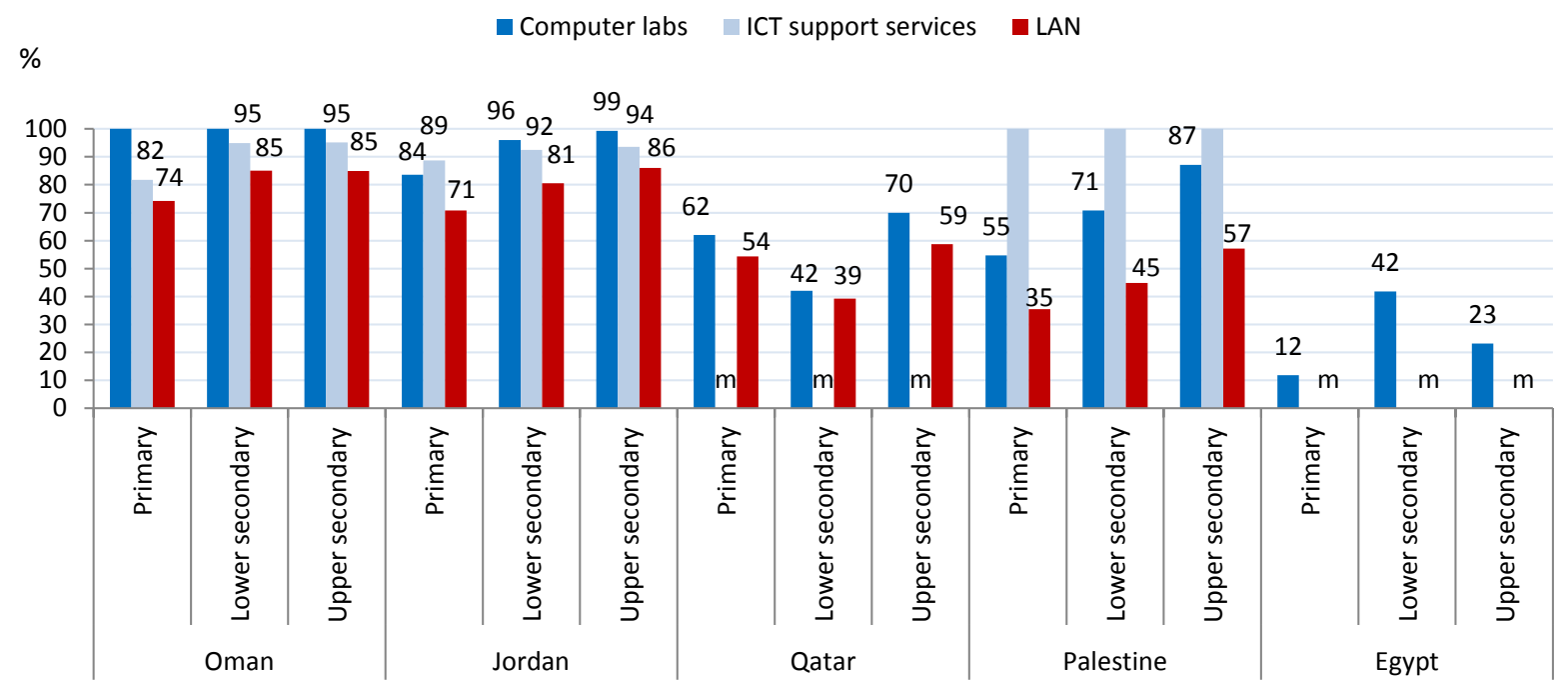

Notes: $m=$ missing data.

Data for Egypt reflect the academic year ending in 2010. Data for Palestine reflect the academic year ending in 2012. Data for Palestine reflect only the West Bank. While total data on ICT support services are missing for Qatar, they are present in $100 \%$ of public institutions.

Source: UIS database.

In Jordan, where the Ministry of Education has been making strong efforts to integrate laboratories in all schools, $84 \%, 96 \%$ and $99 \%$ of primary, lower secondary and upper secondary educational institutions, respectively, now have functional computer laboratories (Jordan, 2012). In Oman, laboratories are even more common and, in fact, are universally available at all levels of education.

Data on LANs are available for Jordan, Palestine and Oman, where the share of schools with LANs increases according to education level. While the share of schools with both computer laboratories and LANs increases by education level in these three countries, more schools overall have laboratories than LANs. This difference is more marked in Palestine where $55 \%$, $71 \%$ and $87 \%$ of primary, lower secondary, and upper secondary educational institutions are equipped with a lab, respectively, compared to $35 \%, 45 \%$ and $57 \%$ that have a LAN.

For countries with available data on ICT support services, two scenarios are presented. In Palestine, where computer laboratories and LANs are less common, ICT support services are almost universal. This suggests that Palestine is prioritising the effective use of ICT in education, despite challenges in terms of developing and maintaining the infrastructure components related to ICT equipment. 
In contrast, secondary schools in Jordan and all schools in Oman are more likely to have computer laboratories than ICT support services, suggesting a lack of technical or pedagogical support to students and/or teachers in some schools, as well as a lack of support to properly maintain and/or repair ICT tools. In Jordan, for example, an estimated 8,800 computers require maintenance, are damaged, missing parts, or simply need to be installed. Thus, challenges remain which could be addressed through the availability of adequate ICT support services (Jordan, 2012).

In Qatar, data demonstrate a substantial digital divide in relation to infrastructure availability between the public and private sectors (see Box 2). For instance, while $62 \%, 42 \%$ and $70 \%$ of all primary, lower and upper secondary schools, respectively, have a computer laboratory, a laboratory exists in the majority of public institutions. Similarly, most public sector schools also have access to a LAN and ICT support services.

\section{Institutional-level ICT-assisted instruction}

At the institutional level, ICT-assisted instruction is dependent upon the availability of proper infrastructure, i.e. installation and maintenance of electricity and telephone communication facilities, acquisition and maintenance of computers, and Internet connectivity. However, the instructional strategies and technologies employed by countries are just as influenced by national priorities and policies on the use of ICT in education, in addition to financial resources. Human resources also play an important role since teachers and other educational personnel need to use ICT effectively and impart knowledge and skills to pupils. Implementation plans need to evaluate current needs and future goals and ensure that adequate training and support are provided. The ICT-in-Education Toolkit (http://www.ictinedtoolkit.org/usere/login.php) is an online tool that can help policymakers to plan during various phases of ICT in education initiatives (Haddad et al., 2007).

Of the older forms of ICT-assisted instruction, radio-assisted instruction (RAI) has been used as an educational tool since the 1920s, and television-assisted instruction (TAI) since the 1950s, in order to enrich and expand the reach of education. Experience has shown that both types have been successful in expanding educational opportunities on a large scale and at a low cost by: i) targeting young adults who have left primary or secondary schools before graduation, allowing them to follow curricula from a distance; and ii) providing otherwise unavailable instruction in sparsely settled rural and remote areas (Haddad et al., 2007; Trucano, 2010). Radio has an added advantage in rural areas with little or no electrical infrastructure, since these devices can be operated easily using batteries.

These older forms of ICT-assisted instruction are being challenged, as well as enriched, by computers and the Internet due to their greater capacity. Computer-assisted instruction (CAI) and Internet-assisted instruction (IAI) have evolved and diversified at an exponential rate, increasingly merging with older ICT tools to create new platforms for learning and teaching. In the 1980s, the approach of CAl was based on programmed learning or "drill and practice" software, whereas both the software and hardware have since evolved. Currently, there are many new devices that have been specifically designed or are being adopted into classrooms, such as laptops (regular and low-cost), interactive whiteboards, tablets, e-readers, smart phones, etc.

One of the hallmarks of both CAI and IAI is the increased opportunity for interactivity with teachers and other pupils that was not possible through one-way radio and television broadcasts. This interaction may enhance educational quality if used appropriately. On the other hand, because of the increased level of technical sophistication associated with CAI and IAI, 
start-up and maintenance costs are substantially higher than for older technologies. Despite this, it is necessary to consider the gains that CAI and IAI might have in schools, given their potential impact on learning, performance and motivation of both students and teachers, as well as on school management and system-wide organization.

Figure 7 demonstrates the degree to which educational institutions provide different forms of ICT-assisted instruction, ranging from traditional tools, such as RAI and TAI, to more technologically advanced platforms, such as CAI and IAI. The data present the level of access to different ICT-assisted instruction types but do not provide information on usage or the quality of instruction (see Box 3).

According to Figure 7, the five countries in this analysis demonstrate different strategies for integrating ICT-assisted instruction in schools. For example, although the number of computers available in Egypt is not keeping pace with enrolment, and Internet connectivity is lagging behind, the country nonetheless continues to emphasise the integration of CAI. As such, $86 \%$ and $96 \%$ of primary and secondary educational institutions, respectively, have access to this type of ICT-assisted instruction. However, while CAI is regarded as relatively widespread, actual time on task is limited considering the high LCR and LCCIR in the country.

Older types of ICT-assisted instruction are not a priority in Egypt, even though large populations live in rural or remote areas where they are frequently found to serve a useful function. RAI is available in $40 \%$ of primary and secondary schools, while TAI is available in $59 \%$ and $55 \%$ of primary and secondary schools, respectively, often through the use of mobile technology equipped with transmission receivers to the Egyptian Satellite (Nile Sat) television broadcasts, which air educational programmes for children and general literacy programmes. There is no available data on the provision of IAI at the institutional level in Egypt; however, approximately one-half or fewer of all schools in Egypt have access to the Internet, suggesting that IAI is available in no more than a half of total schools.

Palestine also faces challenges in establishing infrastructure to support CAI and IAI across the entire educational system. Previous evidence shows that many computers were outdated and some laboratories are only used during the technology class, which is 45 minutes per week (Pacetti, 2008). According to Figure 7 , slightly more than one-half $(55 \%)$ of primary schools and approximately three-quarters of secondary schools (76\%) have CAI.

Given that less than one-third of all schools have any kind of Internet connection, instruction based on the Internet (i.e. IAI) is even less common, available in just one-fifth of primary (21\%) and one-quarter $(24 \%)$ of secondary educational institutions. In Palestine financing has often been a challenge as the Palestinian Ministry of Education and Higher Education (MoEHE) rarely permits school funds to be used for connecting to the Internet, resulting in a reliance on community donations (Pacetti, 2008).

In contrast to Egypt, Palestine commonly uses older forms of ICT-assisted instruction to help fill gaps left by a lack of infrastructure needed to support CAI and IAI. For example, RAI is universally integrated in primary and secondary educational institutions, while TAl is present in $76 \%$ and $94 \%$ of primary and secondary schools. 
Figure 7. ICT-assisted instruction by type and level of education, 2011

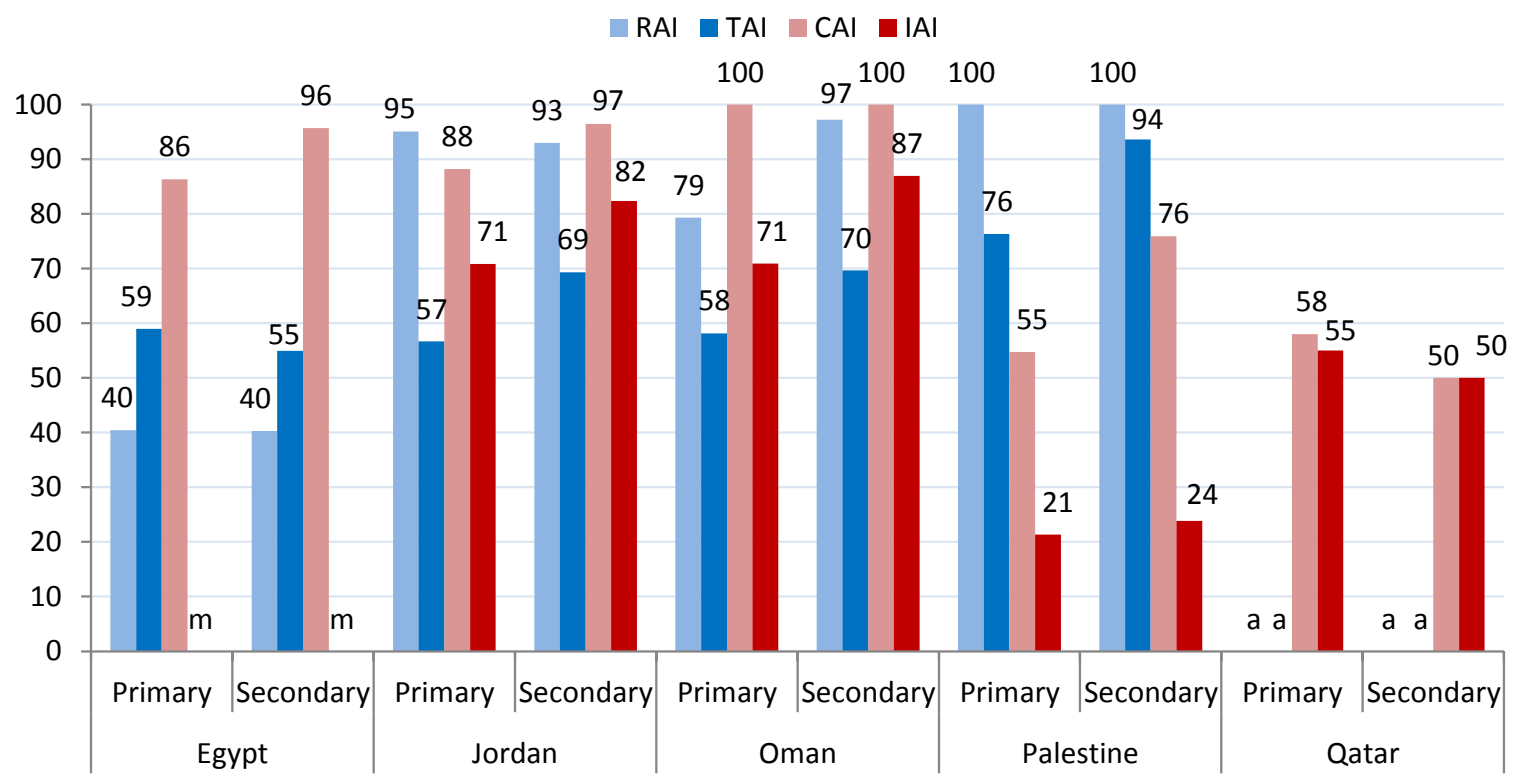

Notes: $m=$ missing data.

$\mathrm{a}=$ category not applicable

Data for Egypt reflect the academic year ending in 2010. Data for Palestine reflect the academic year ending in 2012. Data for Palestine reflect only the West Bank. In Qatar, the categories RAI and TAI are not offered and therefore are not applicable.

Source: UIS database.

\section{Box 3. Four types of ICT-assisted instruction}

ICT-assisted instruction refers to teaching methods or models of instruction delivery that employ ICT in supporting, enhancing and enabling course content delivery. It includes any, all or combinations of the following: radio-, television-, computer- and Internet-assisted instruction.

- Radio-assisted instruction (RAI) includes both radio broadcast education and interactive radio instruction. Radio broadcast education entails an audio lecture or lesson, with printed material for pupils to follow the lecture. Interactive radio instruction (IRI) turns a typically one-way technology into a tool for active learning inside and outside the classroom. It requires that pupils react to questions and exercises through verbal responses to radio programme contributors, group work, and physical and intellectual activities while the programme is on air.

- Television-assisted instruction (TAI) is similar to radio broadcast education, with the additional benefit of video. It helps to bring abstract concepts to life through clips, animations, simulations, visual effects and dramatisation. It can also connect a classroom to the world but shares the same rigid scheduling and lack of interactivity as radio broadcast education.

- Computer-assisted instruction (CAI) is an interactive learning method in which a computer is used by teachers and/or pupils to present instructional material, to perform tasks for learning and to help in selecting and accessing additional pedagogical material.

- Internet-assisted instruction (IAI) refers to an interactive learning method using content from the World Wide Web for pedagogical purposes. 
Jordan and Oman both have strong policy orientations towards providing a wide array of ICTassisted instruction types. CAI is emphasised in Jordan and Oman in both primary and secondary schools. For example, $88 \%$ of primary institutions in Jordan provide CAI and it is almost universally available in secondary education (97\%), while in Oman CAI is universally available at all levels. Similarly, IAI is relatively common in both Jordan (71\%) and Oman (71\%) at the primary level but is more frequently available in secondary schools $-82 \%$ and $87 \%$, respectively.

RAI continues to be common in Jordan and Oman, readily available in $95 \%$ and $79 \%$ of primary schools and $93 \%$ and $97 \%$ of secondary schools, respectively. While emphasised less, TAI is available in just over one-half of primary schools in Jordan (57\%) and Oman (58\%). It is more common at the secondary level, where approximately two-thirds of schools use televisions for educational purposes in Jordan (69\%) and Oman (70\%). While broadcast varieties of RAI and TAI were formerly available in Jordan until 2009 and 2002, respectively, current forms of RAI and TAI use existing hardware in schools for instruction. For example, radios/ recorders are used for English language and Islamic education, while televisions are often used to view educational video tapes (Jordan, 2013).

Finally, although Qatar has relatively high rates of access to computers and the Internet as measured by the LCR and the LCCIR, Figure 7 shows that only $58 \%$ and $50 \%$ of primary and secondary schools offer CAI and $55 \%$ and $50 \%$ offer IAI. This is due to an uneven distribution of resources between the public sector (where CAI and IAI are universally available in all schools) and the private sector (where computers are relatively scarce precluding access to advanced forms of ICT-assisted instruction). Data from Qatar also show that older forms of ICT-assisted instruction, including RAI and TAI, are not used.

\section{Enrolment in programmes offering ICT by gender}

There are three aspects to the digital divide in the Arab states: i) the divide between the Arab world as a whole versus other regions; ii) the divide across Arab states (e.g. large, predominantly rural countries versus small, resource-rich countries); and iii) the divide within Arab states according to demographics, including socio-economic status, location (e.g. urban versus rural), culture and ethnicity.

While the integration of ICT in education may help to bridge the digital divide, it may also exacerbate it in some contexts. This can occur, for example, if particular groups tend to be systematically excluded from educational opportunity and if schools are the only place where certain children can readily access and take advantage of the learning provided by ICT.

Gender can also have an impact on access to, participation in, retention and completion of education (UIS, 2010). Yet, if girls are to leave school ready to participate equally in the knowledge economy, then they too will require the benefits of ICT-assisted instruction, including the knowledge, skills and attitudes imparted by using these tools. Research in OECD countries shows a gap indicating that boys have more experience with technology than girls and are less apprehensive about its use (Blackmore et al., 2003). Fortunately, research also shows that greater experience with computers results in improvements among girls, including those in developing countries (Kozma et al., 2004; Linden et al., 2003; Wagner and Daswani, 2005). 
There has been substantial analysis of the digital divide based on gender (Gorski, 2005; Hilbert, 2012). Other researchers have focused on differences in the manner in which girls and boys access and use ICT to learn and experience the world around them (Sutton, 1991; Volman and van Eck, 2001; Volman et al., 2005). Related to this, household data suggest that boys are more likely than girls to use the Internet at home, work and informal settings in both developed and developing countries (ITU, 2013). Based on the aforementioned perspectives, it is important to measure access to ICT in education not only at an institutional level, but also at the enrolment level, through the lens of gender (Hafkin and Huyer, 2008).

Figure 8 shows sex-disaggregated data based on total enrolment in programmes offering four types of ICT-assisted instruction: RAI, TAI, CAI and IAI. However an important caveat to consider is that gender disparities exist in primary and secondary enrolment in some countries at certain educational levels (i.e. out-of-school children). Therefore some of the following enrolment data in ICT-assisted programmes might suffer from sampling bias resulting in statistical artefacts. In other words, while these data shed light on the extent that girls and boys who are already enrolled in school have access to ICT in education, the data do not take into account pre-existing gender disparities (i.e. out-of-school children) ${ }^{5}$.

\section{Radio-assisted instruction (RAI) and television-assisted instruction (TAI)}

Participation in programmes offering RAI is universal in Palestine (100\%) while Oman and Jordan also report high participation rates (90\% or more). In each country there are no genderbased differences for primary education; however in Jordan at the lower and upper secondary levels, $97 \%$ and $91 \%$ of female students respectively are enrolled in programmes offering RAI, compared to $90 \%$ and $76 \%$ of male students suggesting that boys are disadvantaged in accessing RAl.

In Egypt, about half of all children enrolled are in schools offering RAI. Again, while little difference is found between the sexes at the primary level, female enrolment is higher in secondary education, with $49 \%$ and $54 \%$ of female pupils participating in lower and upper secondary programmes offering RAI compared to $46 \%$ and $50 \%$ of male pupils, respectively. Since girls in Egypt are less likely to be enrolled in primary and secondary levels of education than boys, this suggests that while fewer girls are enrolled, those who are have somewhat higher rates of participation in programmes offering RAI.

Jordan and Palestine have high enrolment rates in programmes offering TAl amongst the sample countries, moreover gender differences are pronounced, especially at the secondary level. In Palestine, approximately half of primary-level female and male pupils are enrolled in programmes with TAl; however at the lower and upper secondary level, $84 \%$ and $86 \%$ of female pupils are enrolled compared to $78 \%$ and $76 \%$ of male pupils, respectively. Similarly, higher shares of females in Jordan are enrolled in programmes offering TAI than males: $68 \%, 80 \%$ and $81 \%$ of female pupils are enrolled in primary, lower secondary and upper secondary programmes offering TAI, compared to $63 \%, 71 \%$ and $73 \%$ of male pupils respectively.

5 Based on gross enrolment ratios (GER) and net enrolment rates (NER), equal proportions of girls and boys are enrolled in primary education in Jordan, Oman, Palestine and Qatar. However, at the secondary level, girls are more likely to be enrolled than boys in Jordan, Palestine and Qatar whereas equal proportions are enrolled in Oman. In Egypt girls are less likely to be enrolled than boys in both primary and secondary levels of education. 
As countries adopt more advanced forms of ICT-assisted instruction, sex-disaggregated enrolment data in regard to older forms of ICT-assisted instruction (e.g. RAI, TAI), which are being used less or entirely phased out, become more difficult to interpret. While not necessarily the situation in Egypt, what may appear to be an advantage for RAI and TAI for girls may simply reflect the tendency that girls are more often enrolled in programmes with older forms of ICTassisted instruction, while boys may be more often enrolled in programmes using computers and the Internet.

Another caveat to consider is pre-existing gender disparity in total enrolment. Gender disparity for numbers of out-of-schools children in rural areas, which often lack ICT infrastructure, can result in misleading data suggesting an advantage for females at the national level, when in fact differences can simply be attributed to higher overall enrolment of girls in urban areas where schools are more likely to offer programmes supported by various ICTs.

Figure 8. Participation of pupils in programmes offering ICT-assisted instruction, by gender, 2011
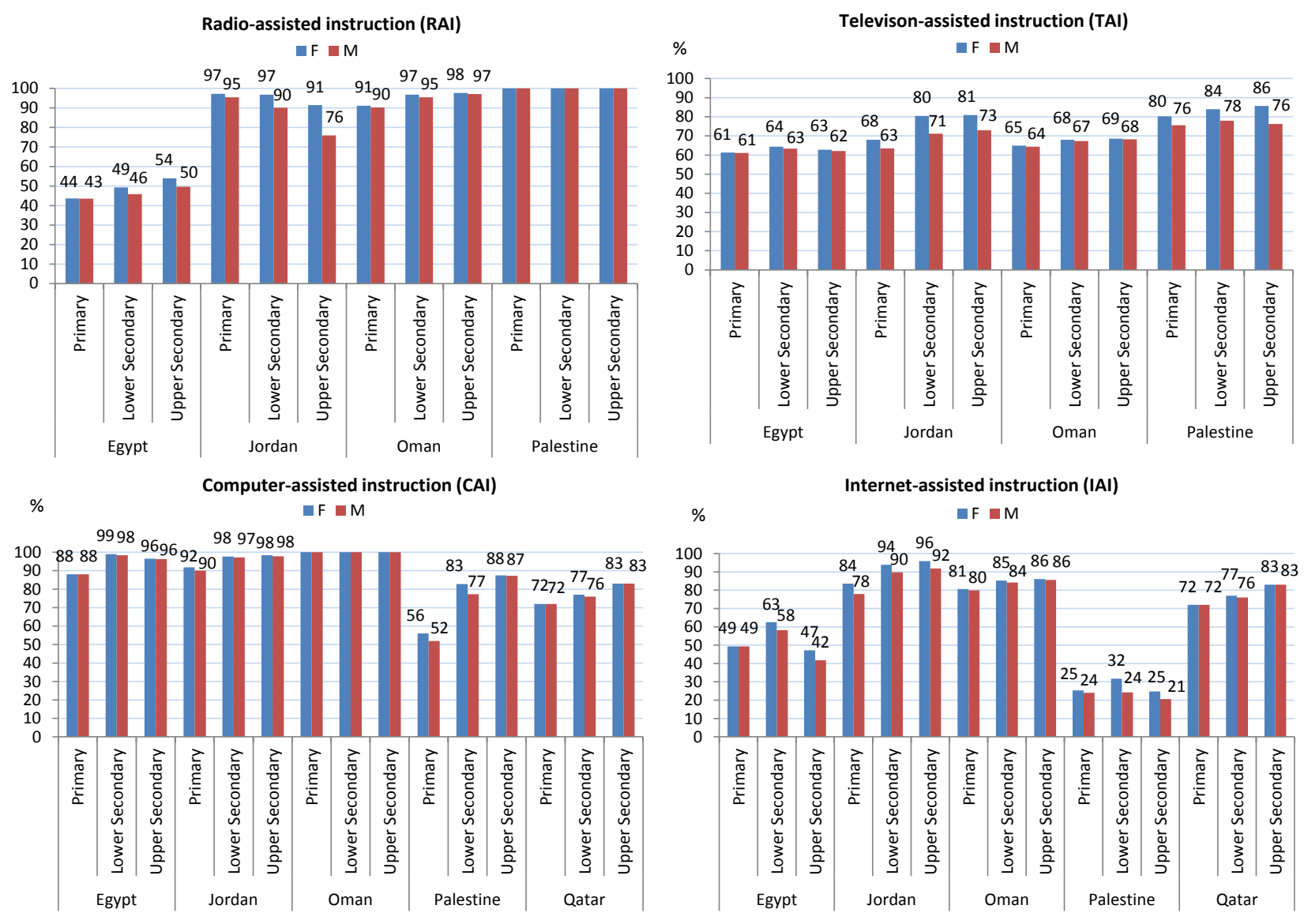

Notes: Data for Egypt reflect the academic year ending in 2010. Data for Palestine reflect the academic year ending in 2012. Data for Palestine reflect only the West Bank. In Qatar, the categories RAI and TAI are not offered and therefore are not applicable.

Source: UIS database. 


\section{Computer-assisted instruction (CAI) and Internet-assisted instruction (IAI)}

Most female and male pupils are enrolled in programmes that offer CAI in Egypt, Jordan, and Oman, where participation rates are about $90 \%$ and above. Nonetheless, as previously mentioned, participation rates do not provide information on usage or gender differences in terms of time on task. For example, while $88 \%$ of both male and female students are enrolled in primary programmes offering CAI in Egypt, overall usage is presumed to be very low given that the learner-to-computer ratio is 120:1. In contrast, usage is presumed to be higher in primary schools offering CAI in Oman where the learner-to-computer ratio is 9:1.

Gender differences emerge in Palestine where girls have a higher participation rate in programmes offering CAI at the primary and lower secondary levels $(56 \%$ and $83 \%$ of female pupils compared to $52 \%$ and $77 \%$ of male pupils, respectively), whereas males and females participate equally in upper secondary programmes.

Gender differences in participation most frequently occur for programmes offering IAI. In Jordan, which has the highest rate of participation amongst countries surveyed, $84 \%, 94 \%$ and $96 \%$ of females pupils are enrolled in primary, lower secondary and upper secondary programmes offering IAI, compared to $78 \%, 90 \%$ and $92 \%$ of males, respectively.

In Egypt and Palestine, where overall enrolment rates in programmes with IAI are substantially lower, gender differences only emerge at the secondary level. For instance, $32 \%$ and $25 \%$ of female pupils at the lower and upper secondary levels are enrolled in programmes offering IAI, compared to $24 \%$ and $21 \%$ of males, respectively. While female pupils may participate more frequently in programmes offering IAI in some countries in the Arab States, household data collected by the International Telecommunication Union (ITU) (2013) offers a different perspective in that females were found to use the Internet less compared to boys. Data from Egypt and Qatar show gender-based differences for Internet usage whereby $24 \%$ and $84 \%$ of boys use the Internet compared to $19 \%$ and $78 \%$ of girls, respectively. Other sources of household data in Egypt, however, show that gender-based difference only begins to emerge at the beginning of upper secondary education (Mandour, 2009). According to the author, stronger integration of ICT in the primary educational curriculum, which is currently lacking in various subjects in Egypt, may help to address gaps in usage.

In Oman, where $80 \%$ or more of female and male pupils are enrolled in programmes offering IAI, gender differences regarding participation do not exist (see Annex 1).

\section{Teaching and learning and ICT in education}

Teachers are frequently considered to be the most important influence on classroom learning and, as such, play an invaluable role in ensuring that pupils use ICT effectively inside and outside of school. While a significant level of teaching and learning occurs peer-to-peer on how to use ICT, teachers need not only know how to instruct pupils to use ICT effectively, but they also require training to use ICT for teaching different subjects in an effort to integrate the use of ICT across the curriculum to enhance the overall learning experience and improve student outcomes including academic achievement (see Box 4). This is especially important since poor or improper usage and management of ICT may, in fact, result in diminished educational outcomes compared to if no ICT had been employed - particularly so if ICT-assisted instruction is inefficiently consuming time that could be used to learn actual content. 
The UNESCO ICT Competency Framework for Teachers is a useful tool to inform education policymakers, educators and providers of professional learning of the role of ICT in educational reform, as well as to assist Member States in developing national ICT competency standards for teachers (http://www.unesco.org/new/en/unesco/themes/icts/teacher-education/unesco-ictcompetency-framework-for-teachers/). It emphasises that it is not enough for teachers to just have ICT competencies and be able to teach them to students. Rather, teachers need to be able to help students become collaborative, problem-solving, creative learners through using ICT in order to be effective citizens and members of the workforce (UNESCO, 2011b).

Ultimately, how teachers are prepared varies from one country to another. Nevertheless, in order to adapt educational curricula to meet the challenges of the information society, the UIS measures teacher training related to ICT preparedness using the following two indicators: i) the proportion of ICT-qualified teachers in schools; and ii) the proportion of teachers trained to teach subjects using ICT.

The proportion of ICT-qualified teachers in schools measures the availability of teachers trained, according to nationally-defined qualification standards, to teach basic computer skills in primary and secondary schools or computing in upper secondary schools. This indicator measures the capacity within the overall teaching workforce but does not provide information on the intensity, quality and effectiveness of the training involved. Since training standards for ICT in education differ between countries, varying in duration from a few weeks to being spread over an entire teacher training programme, this indicator lacks a certain amount of international comparability and, therefore, is perhaps more effective in terms of identifying gaps in the system related to how many teachers require some type of training based on current shares of teachers with relevant instructional responsibilities regarding basic computer skills.

Not only may duration differ, but some countries may adopt policies to train most teachers to be relatively proficient in teaching basic computer skills and/or computing, while others may adopt a policy to provide a more focused training to develop only specialised teachers. While there is no international target, pupils in countries that have greater access to computers (e.g. low learner-to-computer ratios and/or high enrolment in programmes offering CAI), such as Jordan, Oman and Qatar, would benefit from a teaching workforce that is comprised of relatively higher numbers of ICT-qualified teachers to keep pace with demand.

Data from the five countries in this analysis show that the minority of teachers are prepared to teach basic computer skills or computing. Table 2 shows that in Oman, approximately 6\% of teachers are trained to teach basic computer skills or computing (i.e. ICT-qualified), while in Egypt the share is even smaller at $2 \%$ to $3 \%$. It has been argued that a lack of specialised personnel who are educated and trained on the use of ICT in education has resulted in a situation where ICT is not effectively employed in schools. However, given the current lack of ICT infrastructure in Egypt, a more comprehensive and systemic strategy - which also aims to broaden the availability of ICT infrastructure-is much needed (Egypt and UNDP, 2010). Consistent with the finding that teaching basic computer skills is not part of the primary-level curriculum in Palestine, no teachers are ICT-qualified to teach basic computer skills at the primary level. Teachers trained to teaching basic computer skills are also in demand in Jordan since $22 \%$ of teachers teach this subject compared to the $9 \%$ that are ICT-qualified.

The proportion of teachers trained to teach subjects using ICT measures the number of teachers trained, according to nationally-defined qualification standards, to teach one or more subjects using ICT to support instruction in the classroom. While countries do not necessarily train large numbers of teachers to teach basic computer skills or computing, they are more likely 
to emphasise training teachers how to use ICT in their classroom instruction. Table 2 shows that in Oman and Palestine the shares of teachers trained to teach children using ICT facilities are higher than those trained to teach basic computer skills or computing. In Oman, for instance, $40 \%, 35 \%$ and $30 \%$ of primary, lower secondary and upper secondary education teachers, respectively, are trained to teach subjects using ICT tools. Given that ICT is usually used more at higher levels of education, it is surprising that fewer upper secondary level teachers are trained than at the primary level.

Policymakers may adopt different training strategies for preparing teachers to instruct using ICT at different levels of education. In Oman, training for primary-level teachers includes courses and workshops organised by the Ministry of Education and delivered either centrally or regionally, while secondary teachers of ICT, who have already had courses in computer science and the use of Microsoft Office, are offered a cascading model of professional development whereby regional core teams attend courses and workshops in the capital and then return to the regions to pass on the knowledge and skills (Oman, 2008).

Amongst those surveyed, Palestine has the largest share of teachers trained to teach subjects using ICT (i.e. $50 \%$ of teachers at all levels). However, $90 \%$ and $80 \%$ of primary and lower secondary teachers are teaching using ICT facilities, suggesting that formal training on how to use ICT in teaching may be inadequately available to a large share of teachers. According to Pacetti (2008), despite existing teacher training, many simply do not use computers during instruction due to a lack of experience, as well as the fact that many computers have become obsolete.

Jordan, which has a strong set of policies aimed at expanding ICT throughout the education system, has introduced several measures to enhance the integration and effectiveness of ICT in education. Recognising the professional nature of teaching, Jordan has provided a substantial level of professional development and training through the promulgation of National Teacher Professional Standards (2006) emphasising: i) the importance of ICT in teaching careers: ii) the teaching-learning processes: and iii) the integration of ICT in curriculum content. For instance, the Ministry of Education required all personnel, particularly principals and teachers, to be ICTliterate. As such, between 2003 and 2009, over 90,000 teachers, principals and other Ministry employees completed the Microsoft ICDL programme as part of the Ministry's effort to ensure basic ICT skills were available to respond to the integration of e-content in curriculum and the use of ICT in management (UNESCO, 2011a).

Special programmes and donor agencies were also active in Jordan to train teachers. This included the work of the Jordan Education Initiative (JEI), World Links, United States Agency for International Development (USAID), and the Canadian International Development Agency (CIDA), as well as private sector companies contracted by the MoE. These programmes were designed to empower teachers, principals and supervisors with skills to integrate ICT in instruction (UNESCO, 2011a). The JEI and World Links for Development initiatives have trained tens of thousands of teachers in innovative ICT-based pedagogical skills, developed e-content and experimented with new technology arrangements, such as electronic whiteboards and oneto-one laptops for students (Jordan, 2010; 2011). Finally, specialised courses were also offered by the Ministry's ICT Directorate in networking, server maintenance and other hardwareoriented training (UNESCO, 2011a). In 2011, 88\% of teachers in Jordan were considered trained to teach using ICT. 
Recognizing the professional nature of a teaching career as opposed to a civil service view of human resource development, Jordan's Ministry of Education has officially recognised all ICT in education training programmes as part of the Teacher Ranking System, whereby successful completion of these programmes allow teachers to increase in rank and subsequently receive financial allowances in addition to their monthly salaries. This policy has helped the Ministry in attracting almost all teachers to enrol in these programmes (UNESCO, 2011a).

Table 2. Teachers and ICT in education by level of education, 2011

\begin{tabular}{|c|c|c|c|c|c|c|c|c|c|c|c|c|c|c|c|c|}
\hline \multirow{3}{*}{ Teachers } & & \multicolumn{3}{|c|}{ Egypt } & \multicolumn{3}{|c|}{ Jordan } & \multicolumn{3}{|c|}{ Oman } & \multicolumn{3}{|c|}{ Palestine } & \multicolumn{3}{|c|}{ Qatar } \\
\hline & & \multirow{2}{*}{ Primary } & \multirow{2}{*}{$\begin{array}{c}\begin{array}{c}\text { Lower } \\
\text { Secondary }\end{array} \\
\%\end{array}$} & \multirow{2}{*}{$\begin{array}{c}\text { Upper } \\
\text { Secondary }\end{array}$} & \multirow[t]{2}{*}{ Primary } & \multirow{2}{*}{\multicolumn{2}{|c|}{$\begin{array}{|cc|}\text { Lower } & \text { Upper } \\
\text { Secondary } & \text { Secondary } \\
\end{array}$}} & \multirow{2}{*}{ Primary } & \multirow{2}{*}{\multicolumn{2}{|c|}{\begin{tabular}{|c|c|} 
Lower & Upper \\
Secondary & Secondary \\
\end{tabular}}} & \multirow[t]{2}{*}{ Primary } & \multirow{2}{*}{\multicolumn{2}{|c|}{\begin{tabular}{|c|c|} 
Lower & Upper \\
Secondary & Secondary \\
\end{tabular}}} & \multirow[t]{2}{*}{ Primary } & \multirow{2}{*}{$\begin{array}{c}\begin{array}{c}\text { Lower } \\
\text { Secondar }\end{array} \\
\%\end{array}$} & \multirow{2}{*}{$\begin{array}{c}\text { Upper } \\
\text { Secondary }\end{array}$} \\
\hline & & & & & & & & & & & & & & & & \\
\hline & & (1) & (2) & (3) & (4) & (5) & (6) & (7) & (8) & (9) & (10) & (11) & (12) & (13) & (14) & (15) \\
\hline \multirow{2}{*}{$\begin{array}{l}\text { ICT-qualified teachers } \\
\text { (to teach basic computer } \\
\text { skills or computing) }\end{array}$} & $M$ & 2 & 3 & 2 & $x[6]$ & $x[6]$ & $9^{a}$ & . & 3 & 6 & . & 10 & 9 & 4 & 7 & 5 \\
\hline & $\mathrm{F}$ & 2 & 3 & 3 & $x[6]$ & $x[6]$ & $x$ & 6 & 5 & 7 & . & 11 & 8 & 4 & 5 & 4 \\
\hline \multirow{2}{*}{$\begin{array}{l}\text { Teachers currently } \\
\text { teaching basic computer } \\
\text { skills or computing }\end{array}$} & $M$ & 2 & 3 & 2 & $x[5]$ & 34 & 18 & . & 3 & 6 & - & 10 & 9 & 4 & 7 & 5 \\
\hline & $\mathrm{F}$ & 2 & 3 & 3 & $x[5]$ & 29 & 17 & 6 & 5 & 7 & - & 11 & 8 & 4 & 5 & 4 \\
\hline \multirow{2}{*}{$\begin{array}{l}\text { Teachers trained to } \\
\text { teach subject(s) using } \\
\text { ICT facilities }\end{array}$} & $M$ & $\ldots$ & $\ldots$ & $\ldots$ & $x[6]$ & $x[6]$ & $88^{a}$ & . & 35 & 30 & 50 & 50 & 50 & 43 & 68 & 100 \\
\hline & $\mathrm{F}$ & $\ldots$ & $\ldots$ & $\ldots$ & $x[6]$ & $x[6]$ & $x$ & 40 & 35 & 30 & 50 & 50 & 50 & $x$ & $x$ & $x$ \\
\hline \multirow{2}{*}{$\begin{array}{l}\text { Teachers currently } \\
\text { teaching subject(s) using } \\
\text { ICT facilities }\end{array}$} & M & $\ldots$ & $\ldots$ & $\ldots$ & $\ldots$ & $\ldots$ & $\ldots$ & . & 35 & 30 & 90 & 80 & 40 & 43 & 68 & 100 \\
\hline & $\mathrm{F}$ & $\ldots$ & $\ldots$ & $\ldots$ & $\ldots$ & $\ldots$ & $\ldots$ & 40 & 35 & 30 & 90 & 80 & 40 & $\mathrm{x}$ & $x$ & $x$ \\
\hline \multirow{2}{*}{$\begin{array}{l}\text { Teachers trained via ICT- } \\
\text { enabled distance } \\
\text { education programmes }\end{array}$} & $M$ & $\ldots$ & $\ldots$ & $\ldots$ & $x[6]$ & $x[6]$ & $15^{\mathrm{a}}$ & . & 1 & 1 & - & - & - & . & . & . \\
\hline & $\mathrm{F}$ & $\ldots$ & $\ldots$ & $\ldots$ & $x[6]$ & $x[6]$ & $x$ & 1 & 1 & 1 & - & - & - & . & . & . \\
\hline
\end{tabular}

Notes:

. Denotes that the category is not applicable.

- Denotes a value equal to nil.

$x$ Denotes data in another column or row

a Data refer to public sector only

Data for Egypt reflect the academic year ending in 2010. Data for Palestine reflect the academic year ending in 2012. Data from Palestine reflect only the West Bank. Primary data from Oman, which represent only the first four grades, are comprised of female teachers only.

In Palestine, basic computer skills are not included in the primary-level curriculum.

For Qatar, there are no sex-disaggregated data for teachers trained to teach subjects using ICT facilities.

Source: UIS database. 
Box 4. ICT usage and learning achievement in mathematics and science: Evidence from the Trends in International Mathematics and Science Study (TIMSS) 2011

Both national and cross-national studies have shown that low levels of learning achievement in school subjects exist in school systems in both developed and developing countries (Martin et al, 2012; Mullis et al., 2012; OECD, 2012). Low levels of achievement tend to be much more prevalent among students from relatively disadvantaged family backgrounds, regardless of national level of achievement (OECD, 2010; Willms, 2006). Since low-incomes families are less likely to have ICTs at home, ICT in education may be ever more important to bridge the digital divide among children from various socio-economic backgrounds.

However, with the global expansion of ICT in education, there is a growing concern about the effectiveness of ICT to improve the quality of education and to improve overall student achievement and other outcome measures such as increasing retention and decreasing dropout. While many studies have been conducted to determine whether or not computers and ICT favourably affect academic achievement and other measures of student outcomes compared to traditional instruction, results have been mixed. A recent study, which summarizes 25 previous meta-analyses based on more than 40 years of research, concluded that computer use in the classroom does have an overall positive effect on achievement (Tamim, Bernard, Borokhovski, Abrami, \& Schmid, 2011). Still, given the imperfect relationship, it can be concluded that ICT does not necessarily lead in improved outcomes. Other factors are also vital including effective teacher training and appropriately linking ICT usage to sound pedagogy.

Table 3 presents 2011 data from TIMSS, which examines data from 63 developed and developing countries on children in the 4th and 8th grades as reported by teachers. While overall TIMSS results demonstrate that computer usage is related to somewhat higher achievement scores for both mathematics and science in all 63 countries studied, data from Jordan, Oman, Palestine and Qatar demonstrate somewhat higher achievement in science amongst $8^{\text {th }}$ graders who use computers, but not in mathematics. Moreover, no difference was found amongst $4^{\text {th }}$ graders in either subject. The explanation for these results is unclear given that usage data are limited. It should also be recognized that in the four countries under examination, schools that are well-equipped with ICT also tend to be from regions of a higher socio-economic status (SES). Therefore, unless the effect of SES can be discounted, correlations between availability of technology and learning outcomes should be approached with caution.

Table 3. Computer usage, activities, and student achievement in mathematics and science among Grade 8 pupils, as reported by teachers, 2011

\begin{tabular}{|c|c|c|c|c|c|c|c|c|}
\hline \multicolumn{9}{|c|}{ MATHEMATICS } \\
\hline & \multicolumn{4}{|c|}{$\begin{array}{l}\text { Computers available for mathematics } \\
\text { lessons }\end{array}$} & \multicolumn{4}{|c|}{$\begin{array}{l}\text { Percent of students whose teachers have them } \\
\text { use computers at least monthly to: }\end{array}$} \\
\hline & \multirow{2}{*}{\begin{tabular}{|c|}
$\begin{array}{c}\text { Percent of } \\
\text { students }\end{array}$ \\
Yes
\end{tabular}} & \multicolumn{3}{|c|}{ Average Achievement } & \multirow{2}{*}{$\begin{array}{c}\text { Explore } \\
\text { mathematics } \\
\text { principles } \\
\text { and concepts }\end{array}$} & \multirow{2}{*}{$\begin{array}{c}\text { Look up } \\
\text { ideas and } \\
\text { information }\end{array}$} & \multirow{2}{*}{$\begin{array}{l}\text { Process and } \\
\text { analyse data }\end{array}$} & \multirow{2}{*}{$\begin{array}{c}\text { Practice } \\
\text { skills and } \\
\text { procedures }\end{array}$} \\
\hline & & Yes & no & \begin{tabular}{|c|}
$\begin{array}{c}\text { Difference } \\
\%\end{array}$ \\
\end{tabular} & & & & \\
\hline Jordan & 53 & 407 & 406 & 0.2 & 44 & 48 & 41 & 47 \\
\hline Oman & 21 & 359 & 369 & -2.7 & 14 & 18 & 12 & 16 \\
\hline Palestine & 27 & 409 & 402 & 1.7 & 19 & 25 & 18 & 21 \\
\hline Qatar & 45 & 405 & 416 & -2.6 & 37 & 40 & 37 & 40 \\
\hline
\end{tabular}

\section{SCIENCE}

\begin{tabular}{|c|c|c|c|c|c|c|c|c|c|}
\hline & \multicolumn{4}{|c|}{ Computers available for science lessons } & \multicolumn{5}{|c|}{$\begin{array}{l}\text { Percent of students whose teachers have them use computers } \\
\text { at least monthly to: }\end{array}$} \\
\hline & \multirow{2}{*}{\begin{tabular}{|c|}
$\begin{array}{c}\text { Percent of } \\
\text { students }\end{array}$ \\
Yes
\end{tabular}} & \multicolumn{3}{|c|}{ Average Achievement } & \multirow{2}{*}{$\begin{array}{c}\text { Look up } \\
\text { ideas and } \\
\text { information }\end{array}$} & \multirow{2}{*}{$\begin{array}{c}\text { Do scientific } \\
\text { procedures } \\
\text { or } \\
\text { experiments }\end{array}$} & \multirow{2}{*}{$\begin{array}{c}\text { Study natural } \\
\text { phenomena } \\
\text { through } \\
\text { simulations }\end{array}$} & \multirow{2}{*}{$\begin{array}{l}\text { Process and } \\
\text { analyse data }\end{array}$} & \multirow{2}{*}{$\begin{array}{c}\text { Practice } \\
\text { skills and } \\
\text { procedures }\end{array}$} \\
\hline & & Yes & no & \begin{tabular}{|c}
$\begin{array}{c}\text { Difference } \\
\%\end{array}$ \\
\end{tabular} & & & & & \\
\hline Jordan & 49 & 457 & 441 & 3.6 & 48 & 44 & 42 & 39 & 46 \\
\hline Oman & 21 & 440 & 414 & 6.3 & 21 & 13 & 16 & 15 & 17 \\
\hline Palestine & 40 & 432 & 412 & 4.9 & 38 & 34 & 33 & 28 & 34 \\
\hline Qatar & 48 & 426 & 409 & 4.2 & 47 & 43 & 44 & 40 & 46 \\
\hline
\end{tabular}

Source: Martin et al., 2012; Mullis et al., 2012 


\section{Conclusions}

Through global initiatives, such as the Millennium Development Goals and the World Summit on the Information Society, the importance of ICT in education is increasingly gaining ground. Governments are increasingly including the integration of ICT in education, enhancing infrastructure, and training human resources into national policies in order to develop their educational systems. One of the roles of the UNESCO Institute for Statistics (UIS), which is the United Nation's repository for statistics on areas mandated to UNESCO, is to contribute to benchmarking and monitoring the integration of and access to ICT in education, through the establishment of internationally comparable and policy-relevant indicators. In this particular vein, the UIS collected data in 2011 from five countries in the Arab States: Egypt, Jordan, Oman, Palestine and Qatar, as part of its regional, demand-driven survey rollout strategy. The questionnaire collected data on ICT in education policy and the curriculum, school level infrastructure, enrolments in programmes offering ICT-assisted instruction, as well as data related to teachers' training in and use of ICT in education.

As mentioned in this report, different types of ICT-assisted instruction have their own strengths and weaknesses. Several factors can influence which ICT tools countries choose to emphasise in their national planning. The share of schools that offer different ICT will also depend on economic, infrastructural (e.g. availability of electricity and Internet connectivity) and human factors, such as teacher training and preparedness.

To some degree, countries will increasingly adopt newer forms of ICT, including computerassisted instruction (CAI) and Internet-assisted instruction (IAI) to keep pace with the evolving information society. Whether or not countries discontinue use of older forms of ICT, such as radio-assisted instruction (RAI) and television-assisted instruction (TAI), is another decision that should be given careful consideration given their potential for filling gaps when newer tools are unavailable (e.g. CAI and IAI). Undoubtedly a myriad of factors will influence national planning for ICT in education, but it is also noteworthy that the ICT landscape is becoming increasingly blurry, given the growing tendency towards the convergence of ICT where computers, especially connected via broadband, can provide an ever-widening array of possibilities for both learning and teaching.

Despite the fact that each of the five countries presented in this report has formally developed policy related to the implementation and use of ICT in their primary and secondary education systems, data show that policy has not necessarily translated to practice. For example, while Jordan, Oman and Qatar have comprehensive recommendations for the integration of ICT in all subject areas across all grades, ICT usage has not fully permeated the curricula in Egypt and Palestine, even though the overwhelming majority of schools are equipped with electricity.

Data presented in this report show the emergence of particular patterns related to ICT in education. In general, Jordan, Oman and Qatar have much higher levels of integration of ICTassisted instruction and the essential infrastructure, including basic hardware (i.e. computers) and Internet connectivity, than Egypt and Palestine. While learner-to-computer ratios (LCRs) are relatively low in Jordan, Oman and Qatar (i.e. 15:1 or less), indicating that fewer children share a computer, they are much higher in Palestine and especially Egypt, where 120 children on average share the same computer ${ }^{6}$. Internet connectivity and access follows a similar pattern. The learner-to-computer connected to the Internet ratio (LCCIR) shows that, while approximately two-thirds of computers in Jordan, Oman and Qatar are connected to the Internet,

6 Significant differences in LCR may exist between schools and regions (e.g. urban versus rural). 
less than one-third is connected in Egypt and Palestine, which further exacerbates access to more advanced forms of ICT-assisted instruction - particularly Internet-assisted instruction. For example, in Egypt and Palestine where LCRs are already high, the primary-level LCCIRs surge to $441: 1$ and $44: 1$, respectively.

As a result, all five countries have developed a unique strategy for implementing ICT-assisted instruction based on their own unique contexts. Except in the case of Palestine, computerassisted instruction (CAI) is most frequently prioritised and likely reflects current importance in policymaking. While Jordan and Oman are more abundant in terms of infrastructure, including computers, computer laboratories, local area networks and ICT support services, to provide broad levels of CAl access to pupils, infrastructure is relatively poor in Palestine and especially in Egypt, suggesting that actual usage is substantially less.

Internet-assisted instruction (IAI) is also becoming increasingly common in Jordan, Oman and Qatar and is now available in more than one-half of educational institutions. However, due to low levels of Internet connectivity, it is less commonly available in Palestine, serving about onequarter or less of schools. Palestine partly compensates for this gap with near universal penetration of older forms of ICT-assisted instruction. For example, whereas radio-assisted instruction (RAI) and television-assisted instruction (TAI) are less frequently used in other countries, RAI is available in all schools and TAl is offered by $76 \%$ and $94 \%$ of primary and secondary schools in Palestine, respectively.

As has been demonstrated in other research, there are many factors - such as gender - at the root of educational exclusion. This report provides sex-disaggregated data on participation rates in programmes offering ICT-assisted instruction based on total enrolment in the countries under analysis. While the data demonstrate that gender is not a strong predictor for exclusion, some gender differences exist, particularly in Jordan and Palestine, but not in all forms of ICT-assisted instruction. Moreover, wherever gender differences do appear, they tend to favour female participation over that of boys. Programmes offering RAI, TAI and IAI show gender differences in participation favouring females, while participation in CAI programmes seems to exhibit few gender differences - with Palestine as the exception. Finally, IAI is the most likely type of ICTassisted instruction to exhibit gender disparity in enrolment and is the case in Egypt, Jordan and Palestine, but not in Oman. Data are not available for Qatar. Again, these data do not shed light on usage, which also needs to be considered. 


\section{Next steps: Looking forward}

The current report has provided a comparative analysis of ICT integration in five Arab States (Egypt, Jordan, Oman, Palestine and Qatar) by looking at four specific types of data: i) use of ICT in policy and key curricular areas (mathematics, sciences, computing, arts, as well as first and second language learning); ii) ICT infrastructure to support the integration of ICT in educational institutions (access to ICT and connectivity); iii) participation in programmes offering ICT; and iv) teacher's use of and training on how to use and teach ICT in the classroom. These data provide a comprehensive picture of ICT access, as well as basic usage of ICT for education, in the target countries.

As ICT adoption and use in the wider socio-economic context of countries becomes more prevalent, it becomes clear that ICT adoption and policies in education are areas that require further study. In this regard, all aspects of the ICT in education ecosystem, such as contents (use of OER, Free and Open Software (FOSS), and other open solutions for learning), access to and use of hardware (devices, including mobile technologies, one-to-one computing options etc.), connectivity, ICT issues related to pedagogy, and learning (including digital literacy, and issues of assessment), as well as teacher training need to be explored in greater detail to have a fuller picture of the contribution of ICT to quality teaching and learning. Demonstrating meaningful impacts on learning and student outcomes in general are also urgently needed to help policymakers better set national priorities and policies.

In such a dynamic, rapidly changing field, where metrics become a key principle to informed decision-making, UNESCO looks forward to future collaboration with Member States in the elaboration of new instruments to collect new types of data. 


\section{References}

Blackmore, J., L. Hardcastle, B. Esme and J. Owens (2003). Effective Use of Information and Communication Technology (ICT) to Enhance Learning for Disadvantaged School Students (Technical Report). Melbourne: Institute of Disability Studies, Deakin University.

Broadband Commission. (2013). Technology, broadband and education: Advancing the education for all agenda. Paris: UNESCO/ITU.

Clark, R. E. (1983). "Reconsidering research on learning from media". Review of Educational Research, 53, 445-449.

Clark, R. E. (1994). "Media will never influence learning". Educational Technology Research and Development, 42(2), 21-29.

Cohen, D. and H. Hill (2001). Learning Policy: When State Education Reform Works. New Haven: Yale University Press.

Dada, Danish (2006). "E-readiness for developing countries: Moving the focus from the environment to the users". The Electronic Journal on Information Systems in Developing Countries. 27, 6, 1-14.

Dede, C. (1996). "Emerging technologies and distributed learning". American Journal of Distance Education, 10(2), 4-36.

Egypt and UNDP. (2010). Egypt Human Development Report 2010: Youth in Egypt: Building our Future. Cairo/New York: Institute of National Planning, Egypt/ United Nations Development Programme (UNDP).

Gorski, P. (2005). "Education equity and the digital divide". Association for the Advancement of Computing in Education Journal, 13(1), 3-45.

Haddad, G., M. Trucano and C. Wacholz (2007). "ICT-in-Education Toolkit for policymakers, planners, and practitioners". Paris: UNESCO and World Bank-InfoDev. http://www.ictinedtoolkit.org/usere/login.php

Hafkin, N. and S. Huyer (2008). "Women and gender in ICT statistics and indicators for development". Information Technologies and International Development, 4(2), 25-41.

Hamdy, Amr. (2007). "ICT education in Egypt". Survey of ICT and education in Africa: Egypt country report. www. Infodev.org

Hilbert, M. (2012). "Digital gender divide or technologically empowered women in developing countries? A typical case of lies, damned lies, and statistics". Women's Studies International Forum, 34(6), 479-489.

ITU (2013). International Telecommunications Union database: Geneva: ITU. http://www.itu.int/ITUD/ict/statistics/Gender/index.html

Jones, R. (2003). "Local and national ICT policies". In: R. Kozma (ed.), Technology, Innovation, and Educational Change: A Global Perspective. pp. 163-194.

Jordan. (2010). Jordan Education Initiative (JEI) 2010: Annual Report. Amman: Jordan Education Initiative.

Jordan. (2011). Ministry of Education Information and Communications Technology Strategy (2011-2015). Amman: Ministry of Education. 
Jordan. (2012). ICT use and diffusion in schools in Jordan. Amman: Ministry of Information and Communications Technology.

Jordan. (2013). Country communication. Amman: Ministry of Education.

Kozma, R. (1991). "Learning with media". Review of Educational Research, 61, 179-221.

Kozma, R. (1994). "Will media influence learning: Reframing the debate". Educational Technology Research and Development, 42(2), 7-19.

Kozma, R. (2003) (ed.). Technology, Innovation, and Educational Change: A Global Perspective. Eugene: International Society for Technology in Education.

Kozma, R.B. (2008). Comparative analysis of policies for ICT in education,In J. Voogt and G. Knezek (eds.), International handbook of information technology in primary and secondary education (Vol. 20, pp. 1083-1096). New York: Springer.

Kozma, R., R. McGhee, E. Quellmalz and D. Zalles (2004). "Closing the digital divide: Evaluation of the World Links program”. International Journal of Educational Development, Vol. 24, No. 4, pp. 361-381.

Linden, L., A. Banerjee and E. Duflo (2003). Computer-assisted Learning: Evidence from a Randomized Experiment. Cambridge: Poverty Action Lab.

Mandour, Dina Atef. (2009). "Impact of ICT on gender gap in Egypt", Working Paper \#004. Cairo: The American University in Cairo, Social Research Centre.

McKinsey and Company. (2005). "Building effective public-private partnerships: Lessons learnt from the Jordan Education Initiative". An initiative of the World Economic Forum and Government of Indonesia. McKinsey and Company.

Mullis, Ina V.S., Michael O. Martin, Pierre Foy \& Alka Arora (2012a). TIMSS 2011 International results in mathematics. Boston, MA: TIMSS and PIRLS International Study Center/ Lynch School of Education, Boston College.

Martin, Michael O, Ina V.S. Mullis, Pierre Foy \& Gabrielle M. Stanco (2012b). TIMSS 2011 International results in mathematics. Boston, MA: TIMSS and PIRLS International Study Center/ Lynch School of Education, Boston College.

OLPC (2013). "One laptop per child". http://laptop.org/en/children/countries/mideast.shtml. Accessed on 22 January 2013.

Organisation for Economic Co-operation and Development (OECD) (2012). Education at a Glance 2012: OECD Indicators. Paris: OECD.

Organisation for Economic Co-operation and Development (OECD) (2011). Against the Odds:

Disadvantaged Students who Succeed in School. Paris: OECD.

Organisation for Economic Co-operation and Development (OECD) (2011). PISA 2009 Results: Students On Line. Digital Technologies and Performance. Paris: OECD Publishing.

Organisation for Economic Co-operation and Development (OECD) (2010). Are the New Millennium Learners Making the Grade? Technology Use and Educational Performance in PISA. Paris: OECD Publishing. 
Organisation for Economic Co-operation and Development (OECD) (2007). Giving Knowledge for Free: The Emergence of Open Educational Resources. Paris: Organisation for Economic Co-operation and Development.

Oman (2008). "ICT and education in the Sultanate of Oman". Muscat: Ministry of Education.

Oman (2011). "The final report on the Inclusive survey of indicators of information and communications technology in the education sector for grade 1-12". Muscat: Ministry of Education, Sultanate of Oman.

Pacetti, Elena (2008). Improving the quality of education in Palestine through e-learning and ICT: the bottom-up approach for a sustainable pedagogy. CEUR Workshop Proceedings, 398, pp. 81-87. http://ceur-ws.org/Vol-398/S3 Pacetti.pdf

Partnership on Measuring ICT for Development (2011). Measuring the WSIS Targets: A Statistical Framework. Geneva: International Telecommunication Union (ITU).

Pedro, Francesc (2012). "Trusting the unknown: The effects of technology use in education". In D. Soumitra and B. Bilbao-Osorio (eds.). The Global Information Technology Report 2012: Living in a Hyperconnected World. Geneva: World Economic Forum and INSEAD.

Scheuermann, F., F. Pedró, \& European Commission. Joint Research Centre. (2009). Assessing the effects of ICT in education: indicators, criteria and benchmarks for international comparisons.

Luxembourg: Publications Office of the European Union ; OECD.

Sutton, R. (1991). "Equity and computers in the schools: A decade of research". Review of Educational Research, 61(4), 475-503.

Tamim, Rana M., Robert M. Bernard, Eugene Borokhovski, Philip C. Abrami, \& Richard F. Schmid (2011). What forty years of research says about the impact of technology on learning: A second-order metaanalysis and validation study. Review of Educational Research, 81(1), pp. 4-28.

Trucano, M (2010). “Interactive Radio Instruction: A successful permanent pilot project?" Retrieved from http://blogs.worldbank.org/edutech/iri

Tyack, D. and L. Cuban (1995). Tinkering toward Utopia. Cambridge: Harvard University Press.

Volman, M. and E. van Eck (2001). "Gender equity and information technology in education: The second decade". Review of Educational Research Winter 2001, Vol. 71, No. 4, pp. 613-634.

Volman, M., E. van Eck, I. Heemskerk and E. Kuiper (2005). "New technologies, new differences. Gender and ethnic differences in pupils' use of ICT in primary and secondary education". Computers and Education, (2005) 35-55.

United Nations (2000). United Nations Millennium Declaration. United Nations General Assembly, Resolution A/RES/55/2, 18 September 2000.

United Nations (2012). Millennium Development Goals. http://www.un.org/millenniumgoals/global.shtml

UNESCO Institute for Statistics (2010). Global Education Digest 2010: Comparing Education Statistics Across the World. Montreal: UIS.

UNESCO (2000). The Dakar Framework for Action. UNESCO: Paris.

UNESCO (2002). Forum on the Impact of Open Courseware for Higher Education in Developing Countries, Final report. Paris, 1-3 July 2002. 
UNESCO (2011a). Transforming Education: The Power of ICT Policies. Paris: UNESCO.

UNESCO (2011b). UNESCO ICT Competency Framework for Teachers. Paris: UNESCO.

UNESCO (2012a). Turning on mobile learning in Africa and the Middle East: Illustrative initiatives and policy implications. Paris: UNESCO.

UNESCO (2012b). 2012 Paris OER Declaration.

http://www.unesco.org/new/fileadmin/MULTIMEDIA/HQ/Cl/Cl/pdf/Events/Paris\%200ER\%20Declaration 01.pdf

Wagner, D.A. and C.J. Daswani (2005). Impact of ICT on Learning in Out-of-school Youth in Andhra Pradesh (India): Preliminary Results. Technical Report. Philadelphia: International Literacy Institute, University of Pennsylvania.

Willms, John Douglas (2006). Learning Divides: Ten Policy QuestionsAbout the Performance and Equity of Schools and Schooling Systems. UIS Working Paper No. 5. Montreal: UIS. 


\section{Annex I. Country profiles}

EGYPT | 2010

\section{INFORMATION AND COMMUNICATION TECHNOLOGY (ICT) IN EDUCATION}

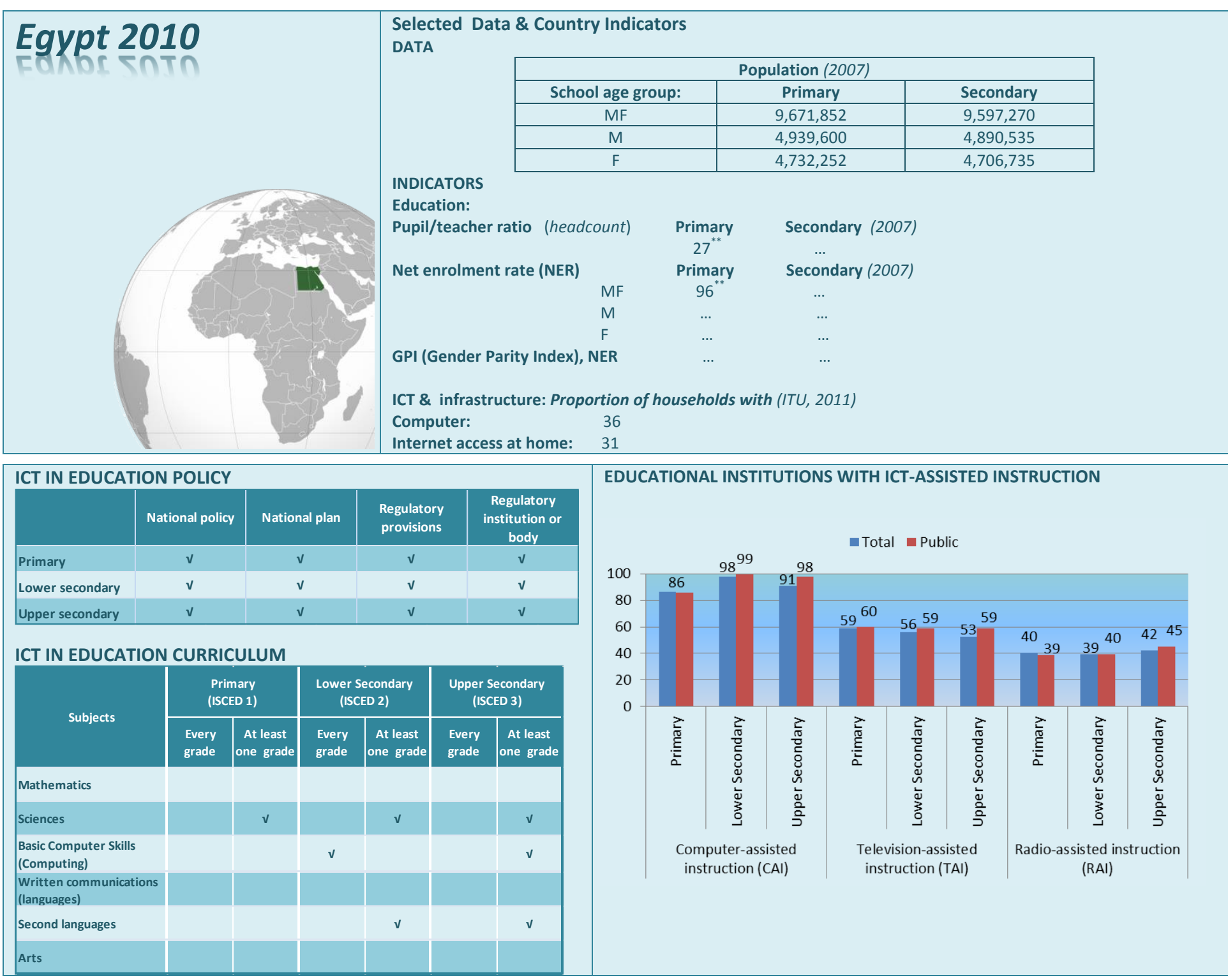

ICT INFRASTRUCTURE IN EDUCATIONAL INSTITUTIONS

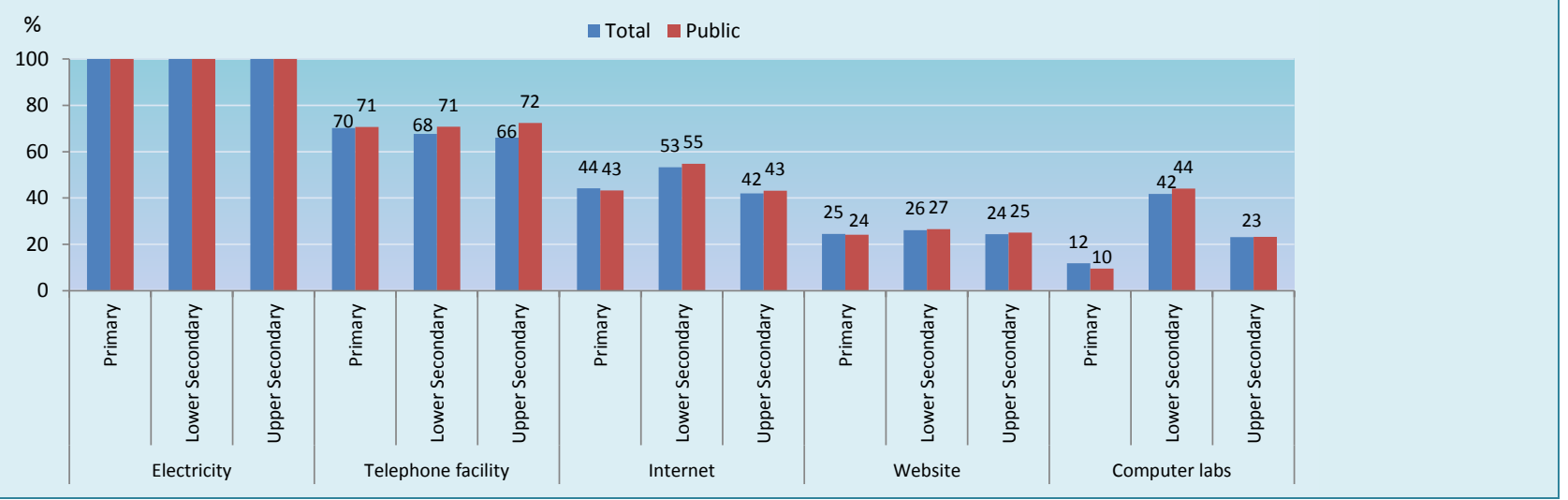




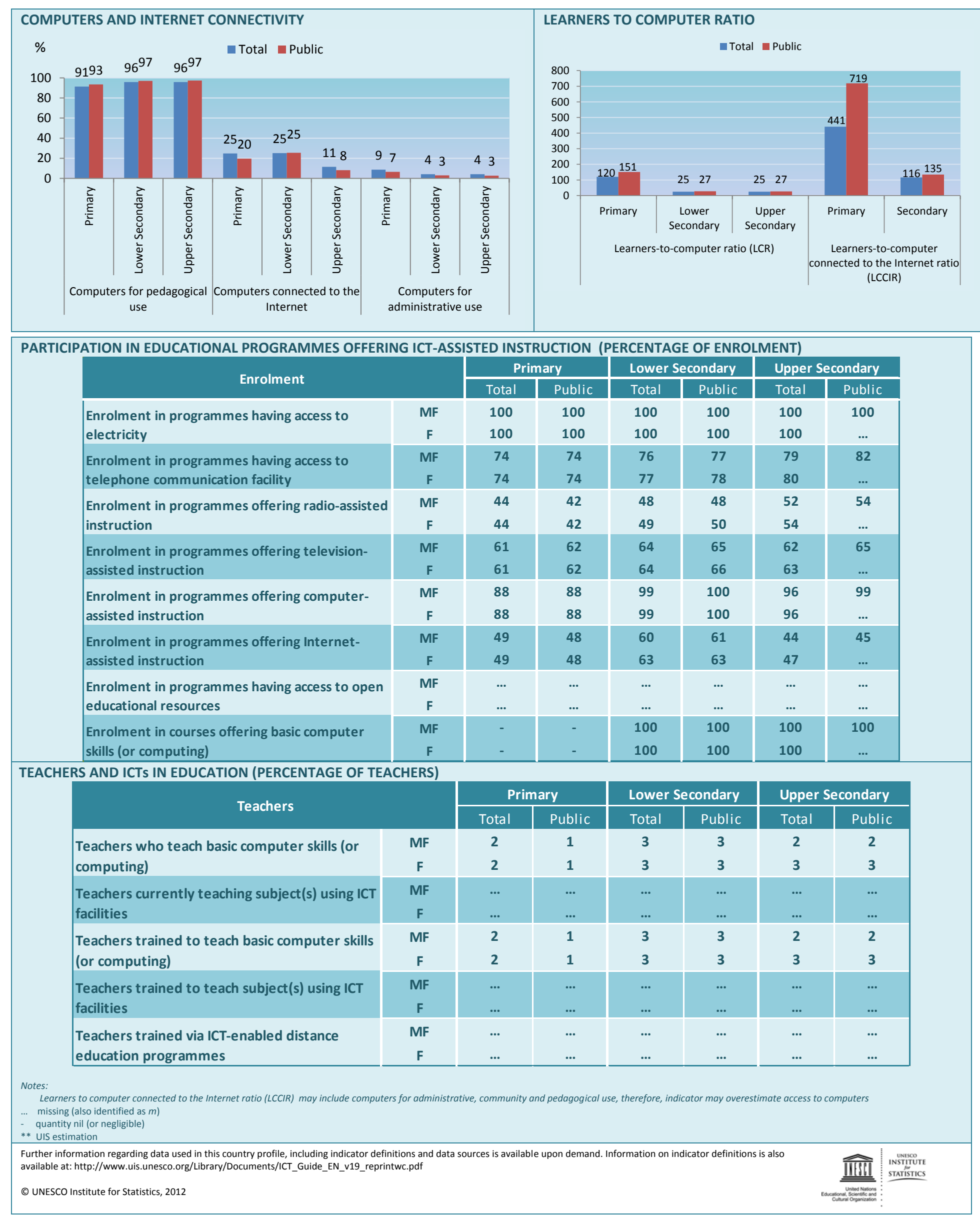




\section{JORDAN | 2011}

\section{INFORMATION AND COMMUNICATION TECHNOLOGY (ICT) IN EDUCATION}

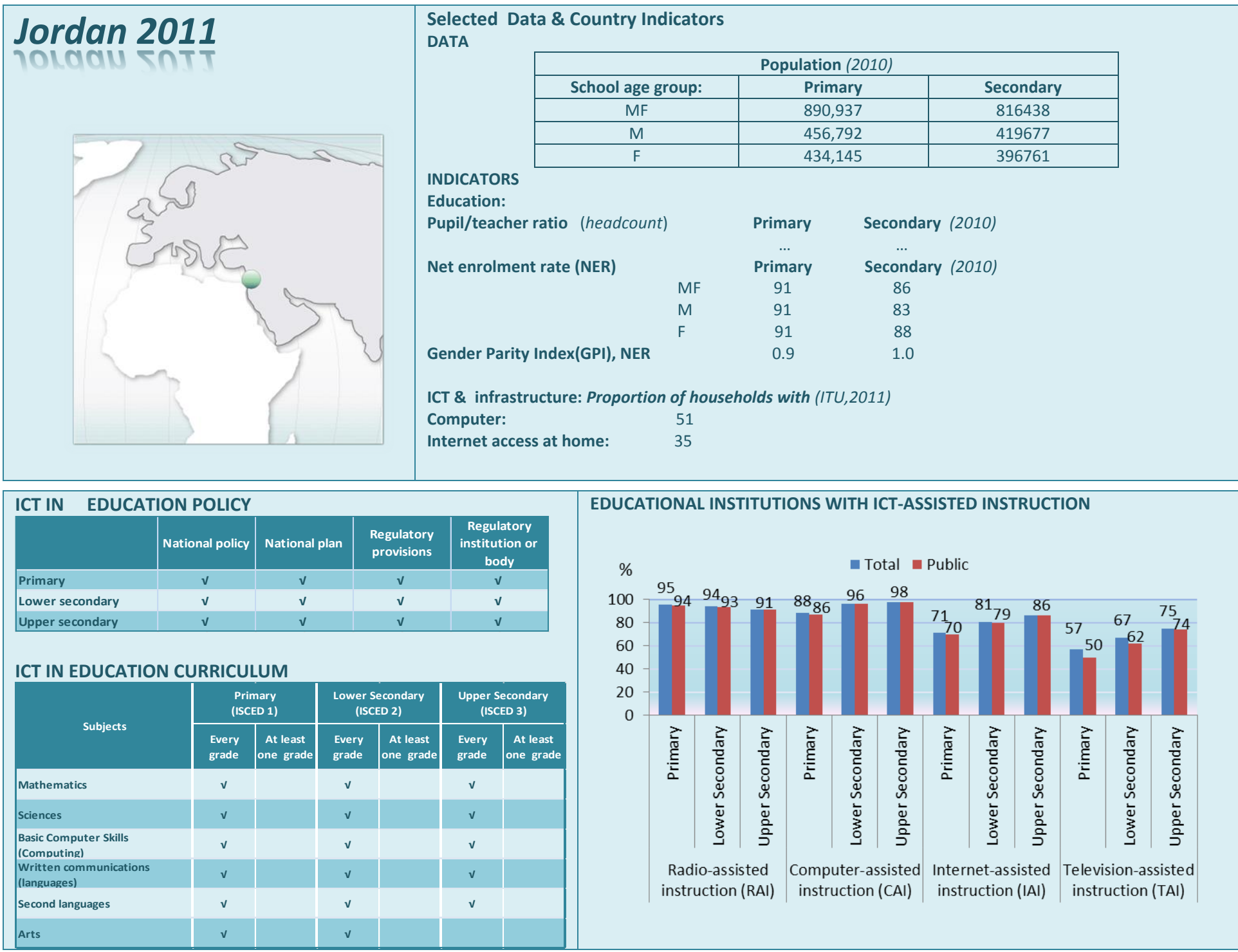

\section{ICT INFRASTRUCTURE IN EDUCATIONAL INSTITUTIONS}

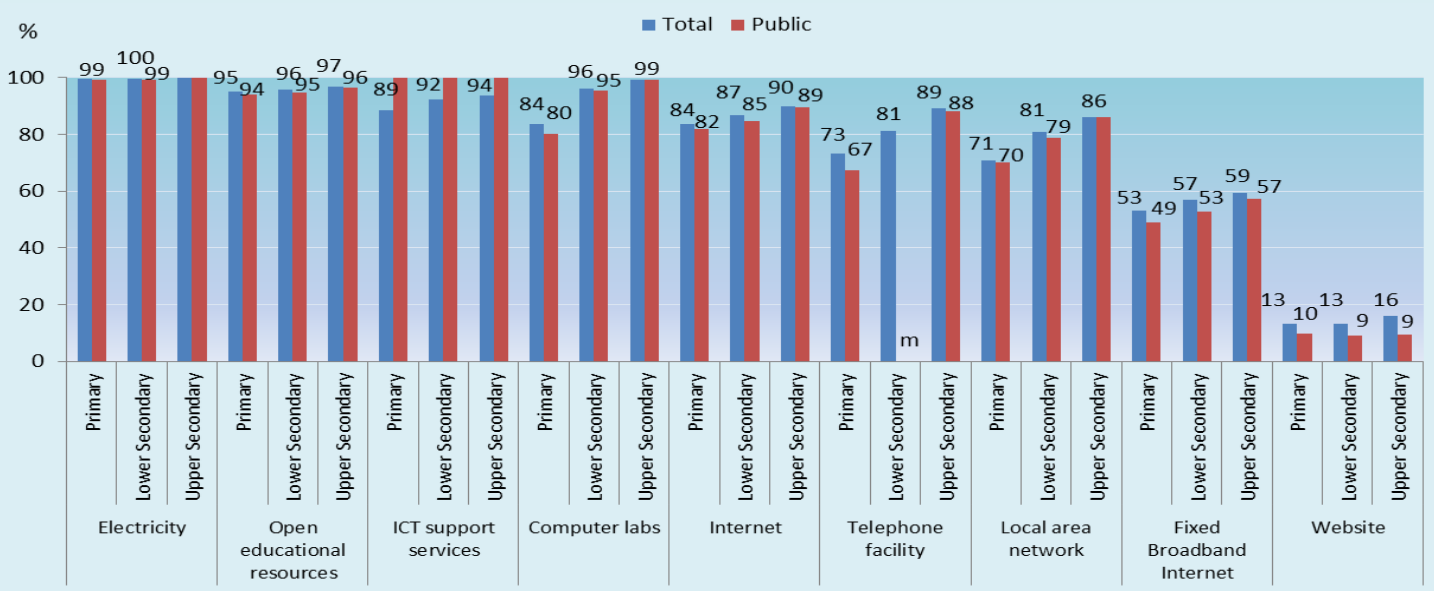




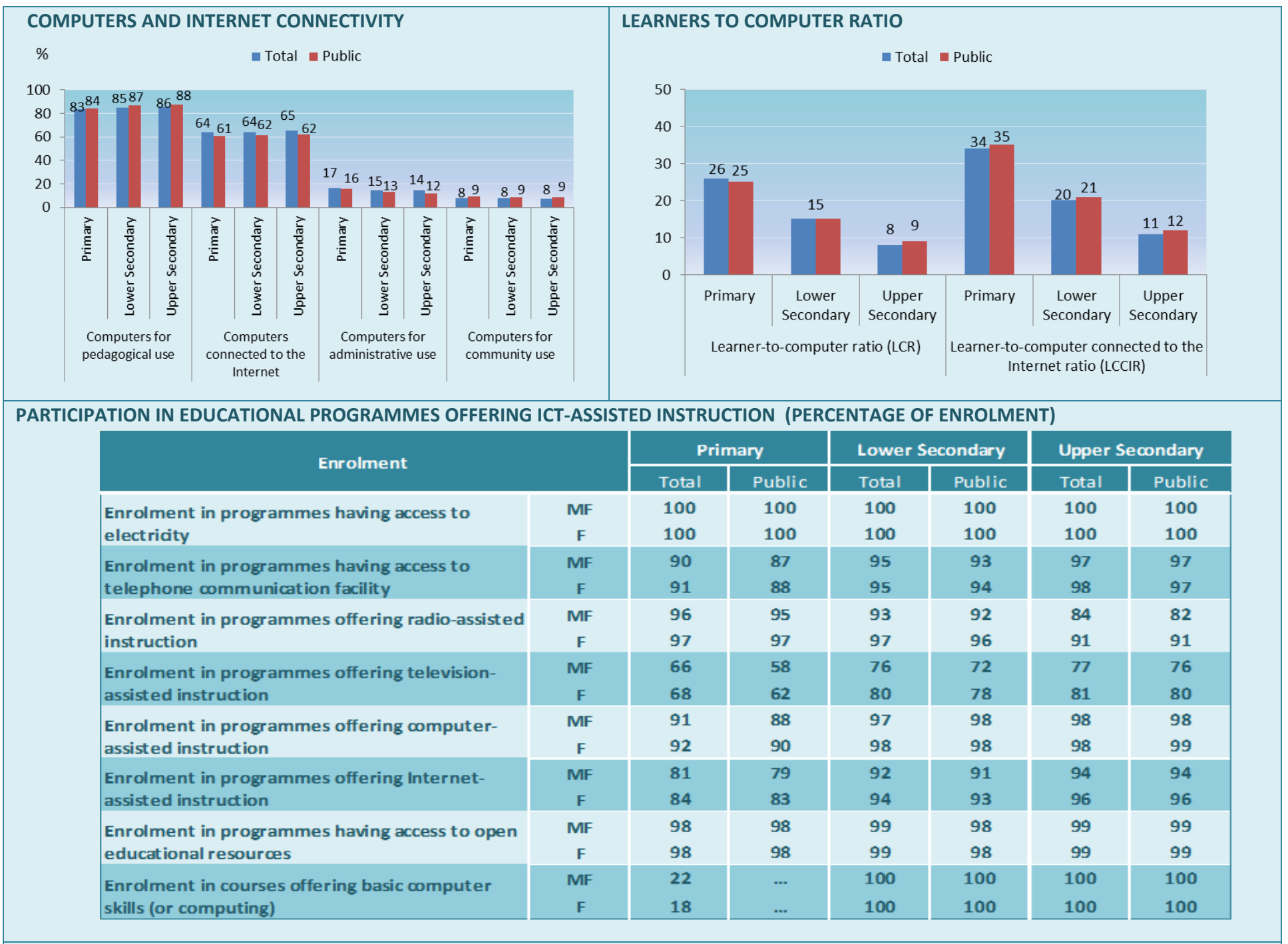

\begin{tabular}{|c|c|c|c|c|c|c|c|}
\hline \multirow{2}{*}{\multicolumn{2}{|c|}{ Teachers }} & \multicolumn{2}{|c|}{ Primary } & \multicolumn{2}{|c|}{ Lower Secondary } & \multicolumn{2}{|c|}{ Upper Secondary } \\
\hline & & Total & Public & Total & Public & Total & Public \\
\hline $\begin{array}{l}\text { Teachers who teach basic computer skills (or } \\
\text { computing) }\end{array}$ & $\begin{array}{c}\text { MF } \\
F\end{array}$ & $\begin{array}{l}x \\
x\end{array}$ & $\begin{array}{l}\cdots \\
\cdots\end{array}$ & $\begin{array}{l}31^{a} \\
29^{a}\end{array}$ & $\begin{array}{l}\cdots \\
\cdots\end{array}$ & $\begin{array}{l}17 \\
17\end{array}$ & $\begin{array}{l}\cdots \\
\cdots\end{array}$ \\
\hline $\begin{array}{l}\text { Teachers currently teaching subject(s) using } \\
\text { ICT facilities }\end{array}$ & $\begin{array}{c}\text { MF } \\
F\end{array}$ & $\cdots$ & $\cdots$ & $\cdots$ & $\cdots$ & $\cdots$ & $\cdots$ \\
\hline $\begin{array}{l}\text { Teachers trained to teach basic computer } \\
\text { skills (or computing) }\end{array}$ & $\begin{array}{c}\text { MF } \\
F\end{array}$ & $\begin{array}{l}\mathbf{x} \\
\cdots\end{array}$ & $\cdots$ & $\begin{array}{l}\mathbf{x} \\
\cdots\end{array}$ & $\cdots$ & $\cdots$ & $\begin{array}{l}9^{b} \\
\cdots\end{array}$ \\
\hline $\begin{array}{l}\text { Teachers trained to teach subject(s) using } \\
\text { ICT facilities }\end{array}$ & $\begin{array}{c}\text { MF } \\
\text { F }\end{array}$ & $\begin{array}{l}\mathbf{x} \\
\cdots\end{array}$ & $\cdots$ & $\begin{array}{l}\mathbf{x} \\
\ldots\end{array}$ & $\cdots$ & $\cdots$ & $\begin{array}{c}88^{b} \\
\cdots\end{array}$ \\
\hline $\begin{array}{l}\text { Teachers trained via ICT-enabled distance } \\
\text { education programmes }\end{array}$ & $\begin{array}{c}\text { MF } \\
F\end{array}$ & $\mathbf{x}$ & $\cdots$ & $\mathbf{x}$ & $\cdots$ & $\cdots$ & $\begin{array}{l}15^{b} \\
\ldots\end{array}$ \\
\hline
\end{tabular}

Notes:

Learners to computer connected to the Internet ratio (LCCIR) may include computers for administrative, community and pedagogical use, therefore, indicator may overestimate access to computers

a including ISCED 1

b including ISCED $1 \& 2$

category not applicable

.. missing (also identified as $m$ )

- quantity nil (or negligible)

Further information regarding data used in this country profile, including indicator definitions and data sources is available upon demand. Information on

indicator definitions is also available at: http://www.uis.unesco.org/Library/Documents/ICT_Guide_EN_v19_reprintwc.pdf

Information and Communication Statistics

(C) UNESCO Institute for Statistics, 2012 
OMAN | 2011

\section{INFORMATION AND COMMUNICATION TECHNOLOGY (ICT) IN EDUCATION}

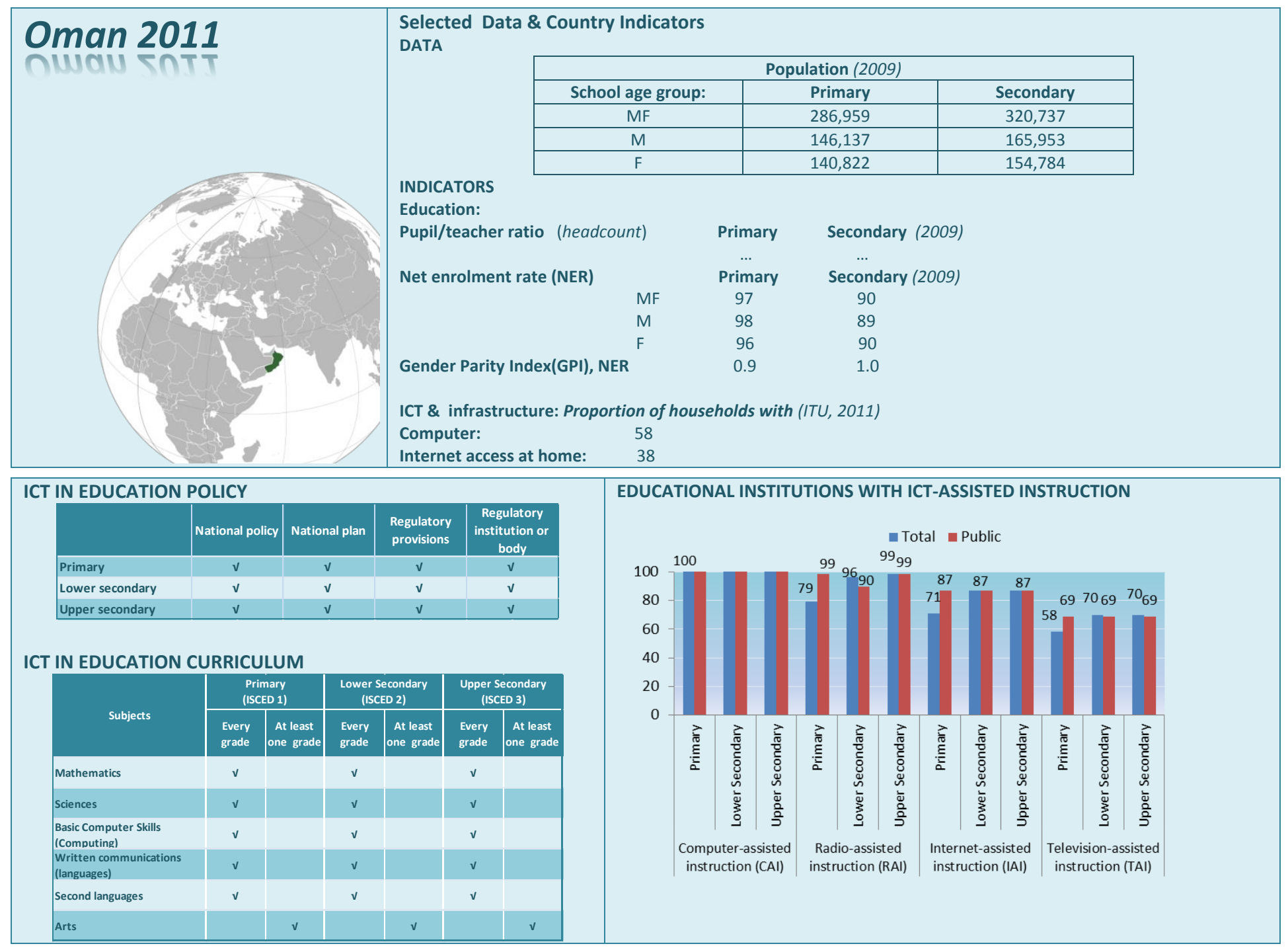

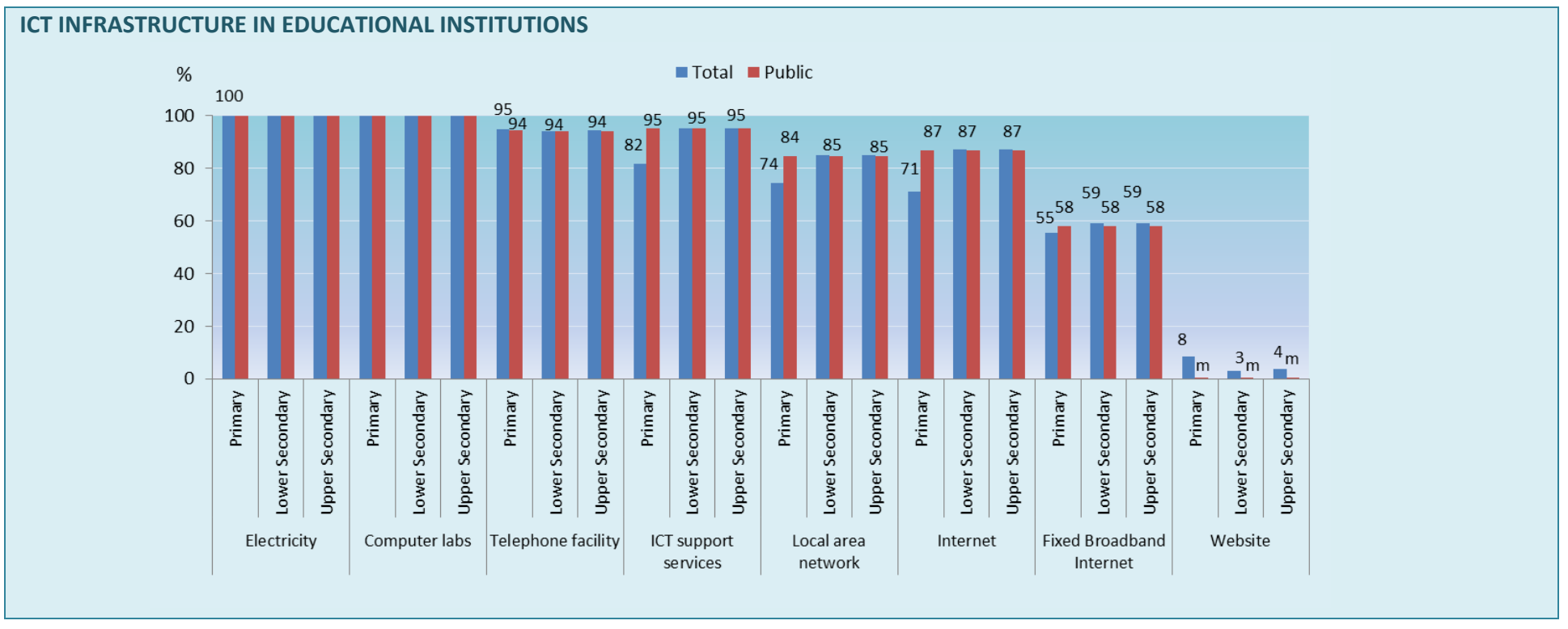


COMPUTERS AND INTERNET CONNECTIVITY

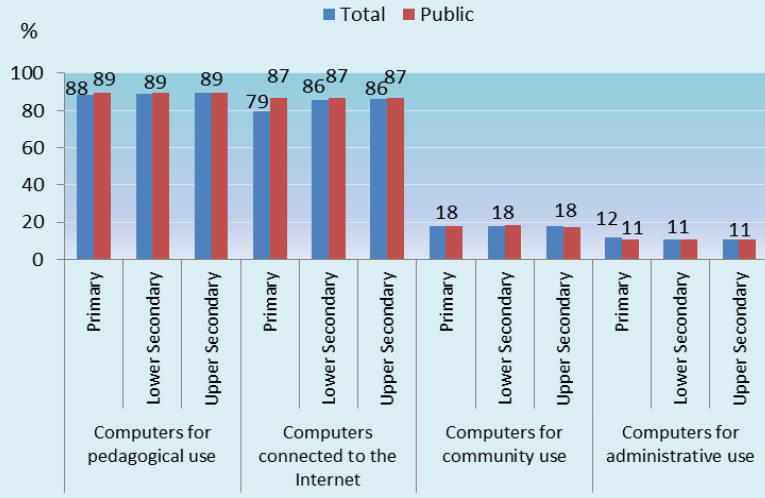

\section{LEARNERS TO COMPUTER RATIO}

- Total $\square$ Public

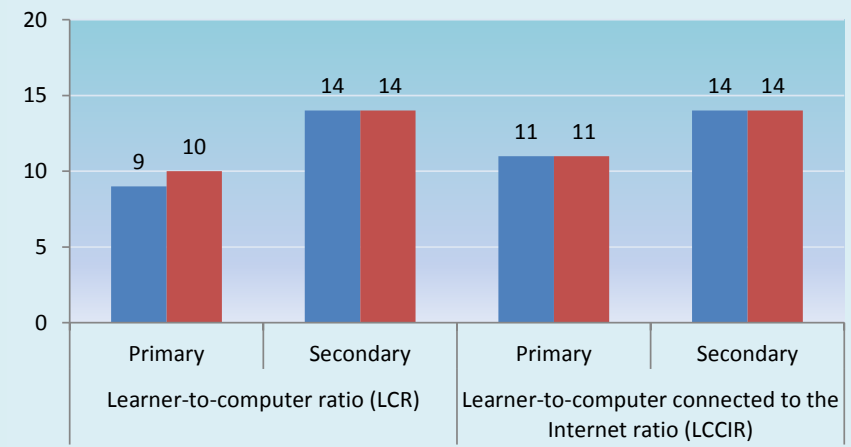

PARTICIPATION IN EDUCATIONAL PROGRAMMES OFFERING ICT-ASSISTED INSTRUCTION (PERCENTAGE OF ENROLMENT)

\begin{tabular}{|c|c|c|c|c|c|c|c|}
\hline \multirow{2}{*}{\multicolumn{2}{|c|}{ Enrolment }} & \multicolumn{2}{|c|}{ Primary } & \multicolumn{2}{|c|}{ Lower Secondary } & \multicolumn{2}{|c|}{ Upper Secondary } \\
\hline & & \multirow{3}{*}{$\begin{array}{c}\text { Total } \\
100 \\
100\end{array}$} & \multirow{3}{*}{$\begin{array}{c}\text { Public } \\
100 \\
100\end{array}$} & \multirow{3}{*}{$\begin{array}{c}\text { Total } \\
100 \\
100\end{array}$} & \multirow{3}{*}{$\begin{array}{c}\text { Public } \\
100 \\
100\end{array}$} & \multirow{3}{*}{$\begin{array}{c}\text { Total } \\
100 \\
100\end{array}$} & \multirow{3}{*}{$\begin{array}{c}\text { Public } \\
100 \\
100\end{array}$} \\
\hline Enrolment in programmes having access to & MF & & & & & & \\
\hline electricity & $\mathbf{F}$ & & & & & & \\
\hline \multirow{2}{*}{$\begin{array}{l}\text { Enrolment in programmes having access to } \\
\text { telephone communication facility }\end{array}$} & MF & 95 & 94 & 95 & 94 & 95 & 94 \\
\hline & $\mathbf{F}$ & 95 & 94 & 95 & 94 & 95 & 94 \\
\hline \multirow{2}{*}{$\begin{array}{l}\text { Enrolment in programmes offering radio-assisted } \\
\text { instruction }\end{array}$} & MF & 91 & 99 & 96 & 99 & 97 & 99 \\
\hline & $\mathbf{F}$ & 91 & 99 & 97 & 99 & 98 & 99 \\
\hline \multirow{2}{*}{$\begin{array}{l}\text { Enrolment in programmes offering television- } \\
\text { assisted instruction }\end{array}$} & MF & 65 & 69 & 68 & 69 & 68 & 69 \\
\hline & $\mathbf{F}$ & 65 & 69 & 68 & 69 & 69 & 69 \\
\hline \multirow{2}{*}{$\begin{array}{l}\text { Enrolment in programmes offering computer- } \\
\text { assisted instruction }\end{array}$} & MF & 100 & 100 & 100 & 100 & 100 & 100 \\
\hline & $\mathbf{F}$ & 100 & 100 & 100 & 100 & 100 & 100 \\
\hline \multirow{2}{*}{$\begin{array}{l}\text { Enrolment in programmes offering Internet- } \\
\text { assisted instruction }\end{array}$} & MF & 80 & 87 & 85 & 87 & 86 & 87 \\
\hline & $F$ & 81 & 87 & 85 & 87 & 86 & 87 \\
\hline \multirow{2}{*}{$\begin{array}{l}\text { Enrolment in programmes having access to open } \\
\text { educational resources }\end{array}$} & MF & $\ldots$ & $\ldots$ & $\ldots$ & $\ldots$ & $\ldots$ & $\ldots$ \\
\hline & $\mathbf{F}$ & $\ldots$ & $\ldots$ & $\ldots$ & $\ldots$ & $\ldots$ & $\ldots$ \\
\hline \multirow{2}{*}{$\begin{array}{l}\text { Enrolment in courses offering basic computer } \\
\text { skills (or computing) }\end{array}$} & MF & 100 & 100 & 100 & 100 & 100 & 100 \\
\hline & $\mathbf{F}$ & 100 & 100 & 100 & 100 & 100 & 100 \\
\hline
\end{tabular}

\section{TEACHERS AND ICTs IN EDUCATION (PERCENTAGE OF TEACHERS)}

\begin{tabular}{|c|c|c|c|c|c|c|c|}
\hline \multirow{2}{*}{\multicolumn{2}{|c|}{ Teachers }} & \multicolumn{2}{|c|}{ Primary } & \multicolumn{2}{|c|}{ Lower Secondary } & \multicolumn{2}{|c|}{ Upper Secondary } \\
\hline & & Total & Public & Total & Public & Tota I & Public \\
\hline $\begin{array}{l}\text { Teachers who teach basic computer skills (or } \\
\text { computing) }\end{array}$ & MF & $\begin{array}{l}6 \\
6\end{array}$ & 5 & $\begin{array}{l}4 \\
5\end{array}$ & $\begin{array}{l}4 \\
4\end{array}$ & $\begin{array}{l}7 \\
7\end{array}$ & $\begin{array}{l}6 \\
6\end{array}$ \\
\hline $\begin{array}{l}\text { Teachers currently teaching subject(s) using ICT } \\
\text { facilities }\end{array}$ & MF & $\begin{array}{l}40 \\
40\end{array}$ & 40 & $\begin{array}{l}35 \\
35\end{array}$ & $\begin{array}{l}35 \\
35\end{array}$ & $\begin{array}{l}30 \\
30\end{array}$ & $\begin{array}{l}30 \\
30\end{array}$ \\
\hline $\begin{array}{l}\text { Teachers trained to teach basic computer skills } \\
\text { (or computing) }\end{array}$ & $\begin{array}{c}\text { MF } \\
\text { F }\end{array}$ & $\begin{array}{l}6 \\
6\end{array}$ & 5 & $\begin{array}{l}4 \\
5\end{array}$ & $\begin{array}{l}4 \\
4\end{array}$ & $\begin{array}{l}7 \\
7\end{array}$ & $\begin{array}{l}6 \\
6\end{array}$ \\
\hline $\begin{array}{l}\text { Teachers trained to teach subject(s) using ICT } \\
\text { facilities }\end{array}$ & MF & $\begin{array}{l}40 \\
40\end{array}$ & $\begin{array}{l}40 \\
40\end{array}$ & 35 & $\begin{array}{l}35 \\
35\end{array}$ & 30 & $\begin{array}{l}30 \\
30\end{array}$ \\
\hline $\begin{array}{l}\text { Teachers trained via ICT-enabled distance } \\
\text { education programmes }\end{array}$ & $\begin{array}{c}\text { MF } \\
\text { F }\end{array}$ & $\begin{array}{l}1 \\
1\end{array}$ & $\begin{array}{l}1 \\
1\end{array}$ & $\begin{array}{l}1 \\
1\end{array}$ & $\begin{array}{l}1 \\
1\end{array}$ & $\begin{array}{l}1 \\
1\end{array}$ & $\begin{array}{l}1 \\
1\end{array}$ \\
\hline
\end{tabular}

Notes:

Learners to computer connected to the Internet ratio (LCCIR) may include computers for administrative, community and pedagogical use, therefore, indicator may overestimate access to computers

category not applicable

missing (also identified as $m$ )

quantity nil (or negligible)

Further information regarding data used in this country profile, including indicator definitions and data sources is available upon demand. Information indicator definitions is also available at: http://www.uis.unesco.org/Library/Documents/ICT_Guide_EN_v19_reprintwc.pdf

Information and Communication Statistics

(c) UNESCO Institute for Statistics, 2012

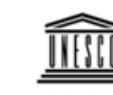

UNESCO
INSTITUTE STATISTICS 
PALESTINE (WEST BANK) | 2012

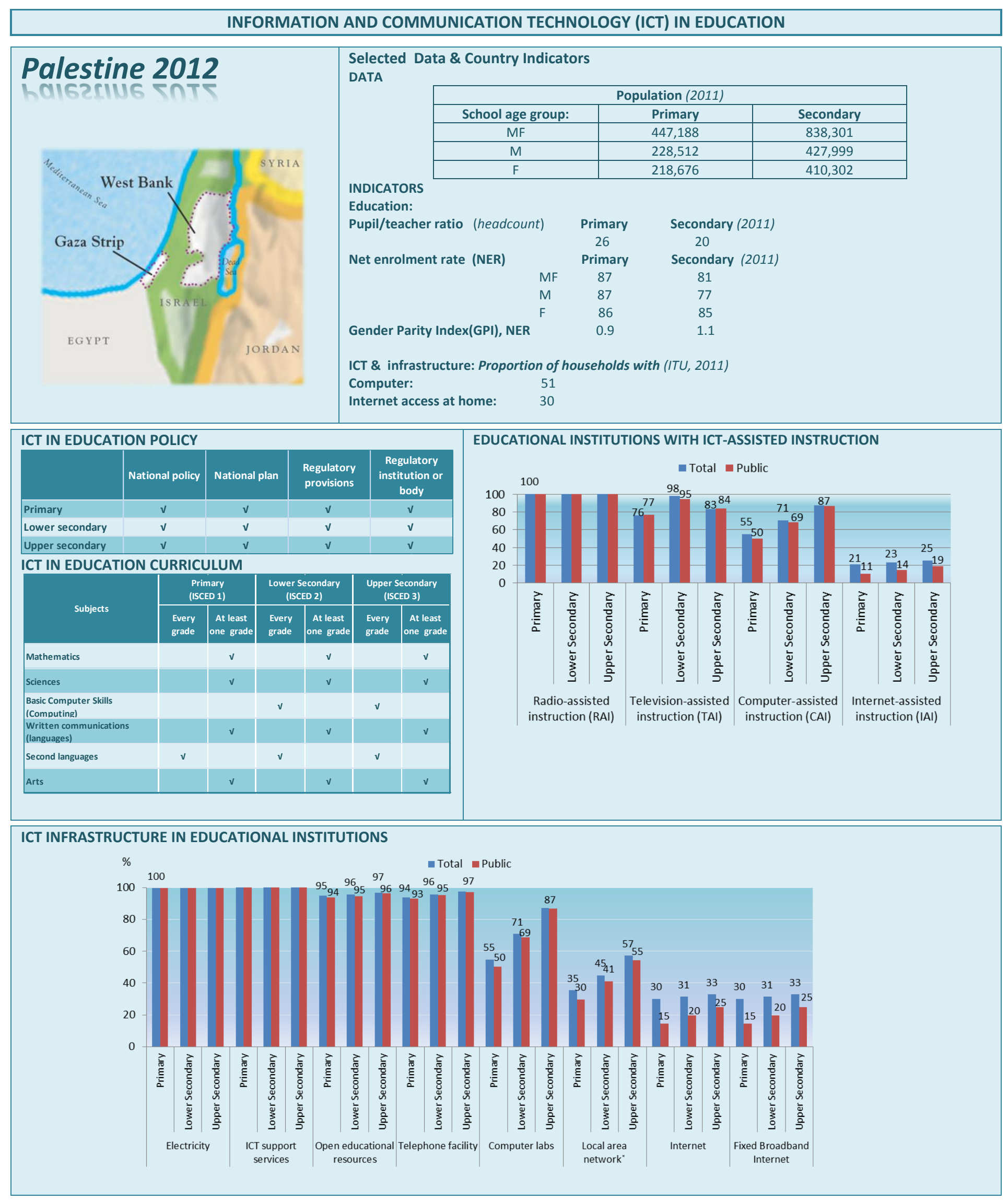




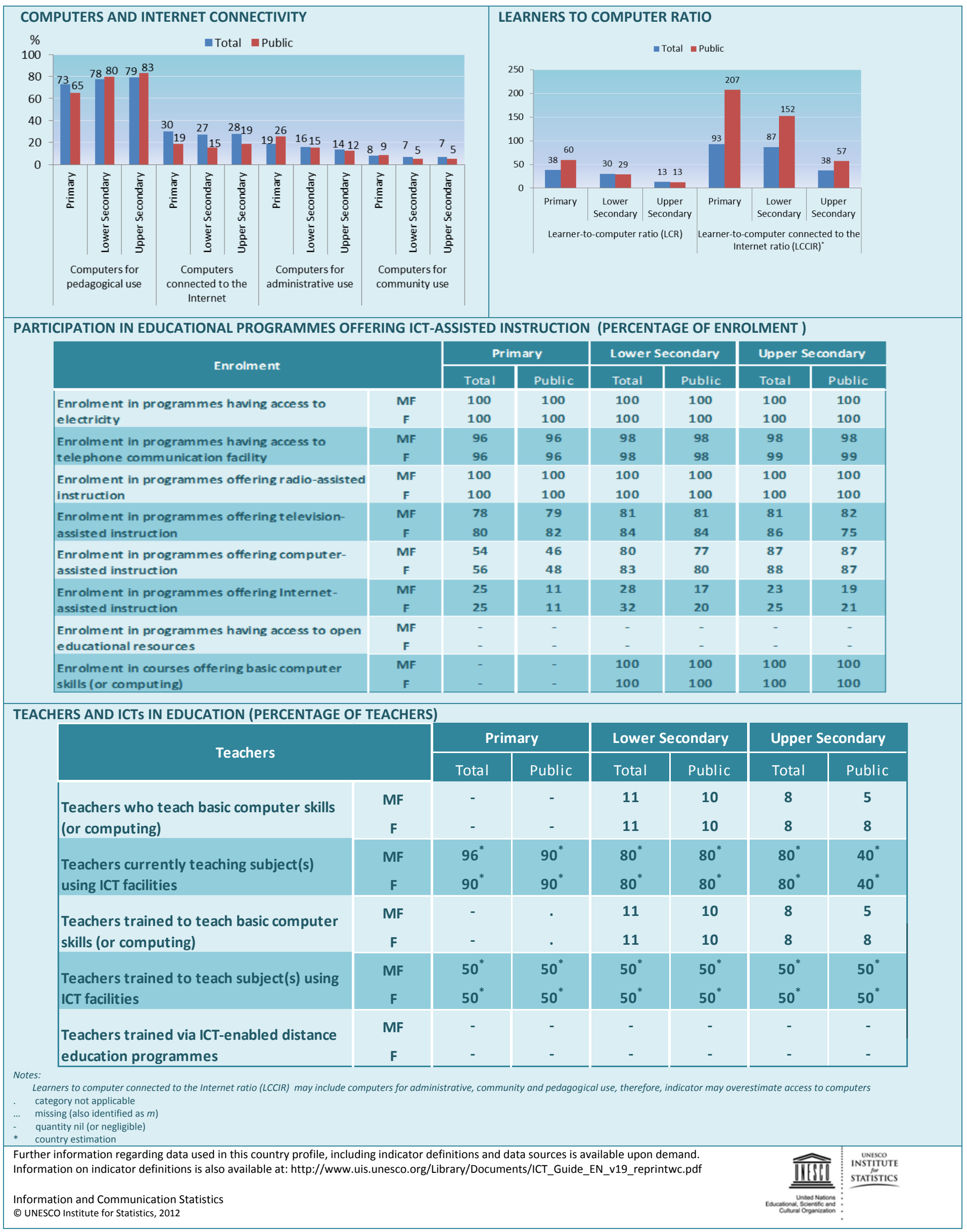


QATAR | 2011

\section{INFORMATION AND COMMUNICATION TECHNOLOGY (ICT) IN EDUCATION}

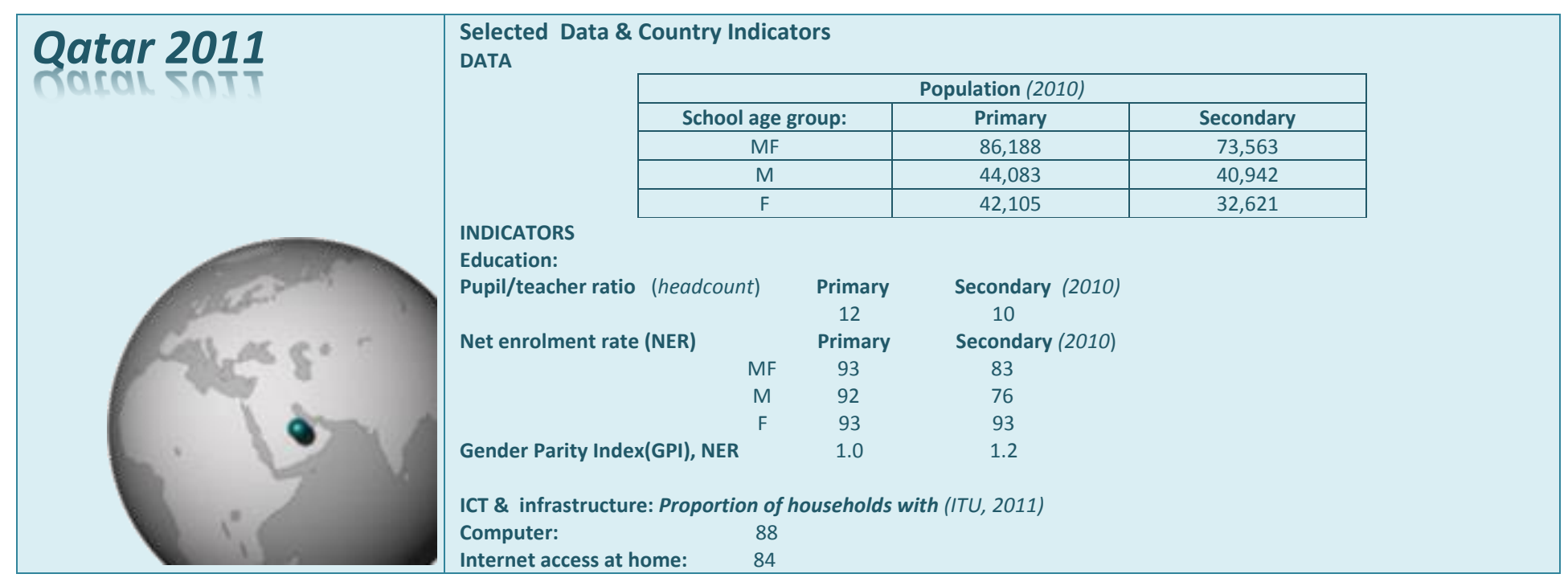

\begin{tabular}{|c|c|c|c|c|}
\hline \multicolumn{5}{|c|}{ ICT IN EDUCATION POLICY } \\
\hline & $\begin{array}{c}\text { National } \\
\text { policy }\end{array}$ & $\begin{array}{c}\text { National } \\
\text { plan }\end{array}$ & $\begin{array}{l}\text { Regulatory } \\
\text { provisions }\end{array}$ & $\begin{array}{c}\text { Regulatory } \\
\text { institution } \\
\text { or body }\end{array}$ \\
\hline Primary & v & v & $v$ & $\mathrm{v}$ \\
\hline Lower secondary & v & v & v & v \\
\hline Upper secondary & $\mathbf{v}$ & v & $v$ & $\mathrm{v}$ \\
\hline
\end{tabular}

ICT IN EDUCATION CURRICULUM

\begin{tabular}{|c|c|c|c|c|c|c|}
\hline \multirow{2}{*}{ Subjects } & \multicolumn{2}{|c|}{$\begin{array}{l}\text { Primary } \\
\text { (ISCED 1) }\end{array}$} & \multicolumn{2}{|c|}{$\begin{array}{l}\text { Lower Secondary } \\
\text { (ISCED 2) }\end{array}$} & \multicolumn{2}{|c|}{$\begin{array}{l}\text { Upper Secondary } \\
\text { (ISCED 3) }\end{array}$} \\
\hline & $\begin{array}{l}\text { Every } \\
\text { grade }\end{array}$ & \begin{tabular}{|c} 
At least \\
one grade
\end{tabular} & $\begin{array}{l}\text { Every } \\
\text { grade }\end{array}$ & $\begin{array}{c}\text { At least } \\
\text { one grade }\end{array}$ & $\begin{array}{l}\text { Every } \\
\text { grade }\end{array}$ & $\begin{array}{l}\text { At least } \\
\text { one grade }\end{array}$ \\
\hline Mathematics & $v$ & & $v$ & & $v$ & \\
\hline Sciences & $v$ & & $v$ & & $v$ & \\
\hline $\begin{array}{l}\text { Basic Computer Skills } \\
\text { (Computing) }\end{array}$ & $\mathbf{v}$ & & $v$ & & $v$ & \\
\hline $\begin{array}{l}\text { Written communications } \\
\text { (languages) }\end{array}$ & $v$ & & $v$ & & v & \\
\hline Second languages & $v$ & & $v$ & & $v$ & \\
\hline Arts & v & & $v$ & & $v$ & \\
\hline
\end{tabular}

\section{EDUCATIONAL INSTITUTIONS WITH ICT-ASSISTED INSTRUCTION}

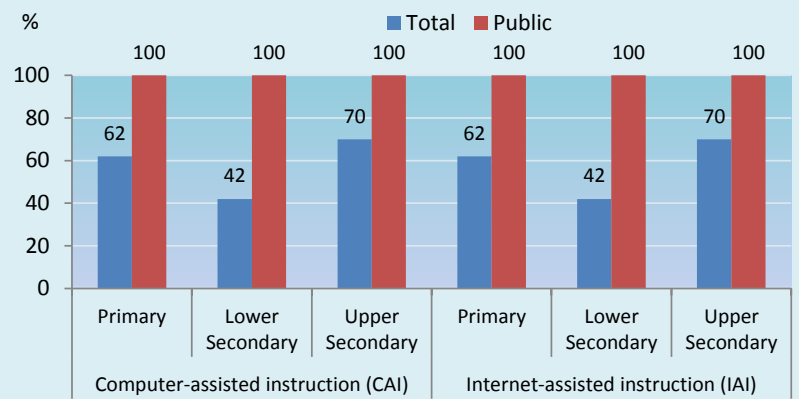

INFRASTRUCTURE IN EDUCATIONAL INSTITUTIONS

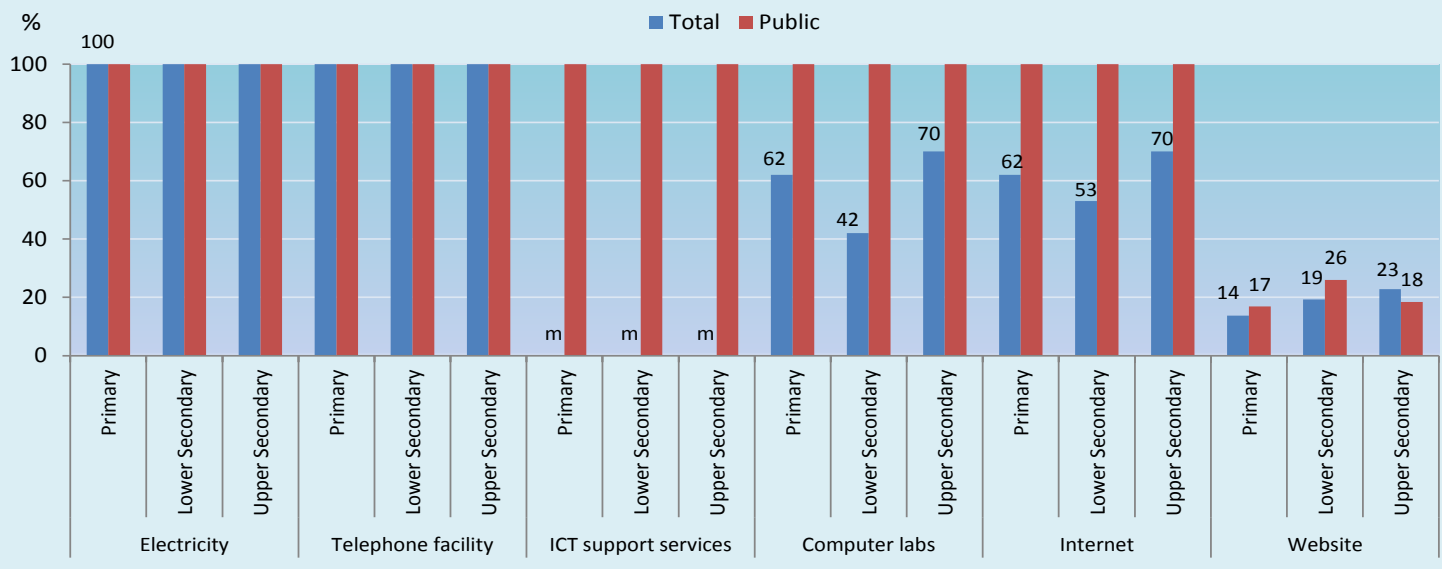




\section{COMPUTERS AND INTERNET CONNECTIVITY}

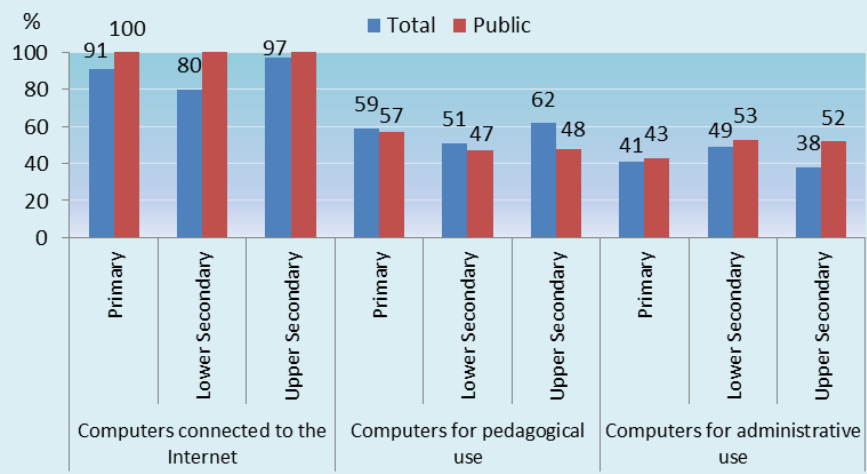

LEARNERS TO COMPUTER RATIO

Total Public

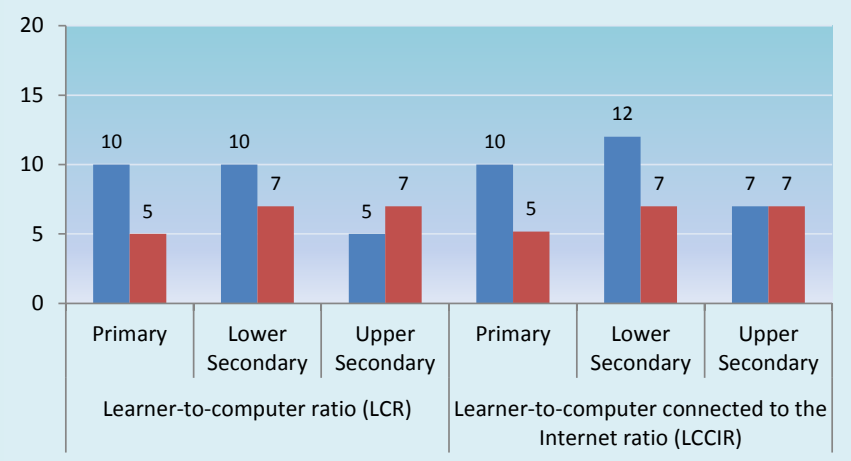

PARTICIPATION IN EDUCATIONAL PROGRAMMES OFFERING ICT-ASSISTED INSTRUCTION (PERCENTAGE OF ENROLMENT)

\begin{tabular}{|c|c|c|c|c|c|c|c|}
\hline \multirow{2}{*}{\multicolumn{2}{|c|}{ Enrolment }} & \multicolumn{2}{|c|}{ Primary } & \multicolumn{2}{|c|}{ Lower Secondary } & \multicolumn{2}{|c|}{ Upper Secondary } \\
\hline & & \multirow{3}{*}{$\begin{array}{c}\text { Total } \\
100 \\
100\end{array}$} & \multirow{3}{*}{$\begin{array}{c}\text { Public } \\
100 \\
100\end{array}$} & \multirow{3}{*}{$\begin{array}{c}\text { Total } \\
100 \\
100\end{array}$} & \multirow{3}{*}{$\begin{array}{c}\text { Public } \\
100 \\
100\end{array}$} & \multirow{3}{*}{$\begin{array}{c}\text { Total } \\
100 \\
100\end{array}$} & \multirow{3}{*}{$\begin{array}{c}\text { Public } \\
100 \\
100\end{array}$} \\
\hline Enrolment in programmes having access to & MF & & & & & & \\
\hline electricity & $\mathbf{F}$ & & & & & & \\
\hline \multirow{2}{*}{$\begin{array}{l}\text { Enrolment in programmes having access to } \\
\text { telephone communication facility }\end{array}$} & MF & 100 & 100 & 100 & 100 & 100 & 100 \\
\hline & $\mathbf{F}$ & 100 & 100 & 100 & 100 & 100 & 100 \\
\hline \multirow{2}{*}{$\begin{array}{l}\text { Enrolment in programmes offering radio-assisted } \\
\text { instruction }\end{array}$} & MF & - & - & - & - & - & - \\
\hline & $\mathbf{F}$ & - & - & - & - & - & - \\
\hline \multirow{2}{*}{$\begin{array}{l}\text { Enrolment in programmes offering television- } \\
\text { assisted instruction }\end{array}$} & MF & - & - & - & - & - & - \\
\hline & $\mathbf{F}$ & - & - & - & - & - & - \\
\hline \multirow{2}{*}{$\begin{array}{l}\text { Enrolment in programmes offering computer- } \\
\text { assisted instruction }\end{array}$} & MF & 72 & 100 & 76 & 100 & 83 & 100 \\
\hline & $\mathbf{F}$ & 72 & 100 & 77 & 100 & 83 & 100 \\
\hline \multirow{2}{*}{$\begin{array}{l}\text { Enrolment in programmes offering Internet- } \\
\text { assisted instruction }\end{array}$} & MF & $72 * *$ & 100 & $76 * *$ & 100 & $83^{* *}$ & 100 \\
\hline & $\mathbf{F}$ & $72 * *$ & 100 & $77^{* *}$ & 100 & $83^{* *}$ & 100 \\
\hline \multirow{2}{*}{$\begin{array}{l}\text { Enrolment in programmes having access to open } \\
\text { educational resources }\end{array}$} & MF & $\ldots$ & 100 & $\ldots$ & 100 & $\ldots$ & 100 \\
\hline & $\mathbf{F}$ & $\ldots$ & 100 & $\ldots$ & 100 & $\ldots$ & 100 \\
\hline \multirow{2}{*}{$\begin{array}{l}\text { Enrolment in courses offering basic computer } \\
\text { skills (or computing) }\end{array}$} & MF & 70 & 100 & 76 & 100 & 83 & 100 \\
\hline & $\mathbf{F}$ & 67 & 100 & 74 & 100 & 83 & 100 \\
\hline
\end{tabular}

\section{TEACHERS AND ICTS IN EDUCATION (PERCENTAGE OF TEACHERS)}

\begin{tabular}{|c|c|c|c|c|c|c|c|}
\hline \multirow{2}{*}{\multicolumn{2}{|c|}{ Teachers }} & \multicolumn{2}{|c|}{ Primary } & \multicolumn{2}{|c|}{ Lower Secondary } & \multicolumn{2}{|c|}{ Upper Secondary } \\
\hline & & \multirow{3}{*}{$\begin{array}{c}\text { Total } \\
4 \\
4\end{array}$} & \multirow{3}{*}{$\begin{array}{c}\text { Public } \\
5 \\
5\end{array}$} & \multirow{3}{*}{$\begin{array}{c}\text { Total } \\
\mathbf{6} \\
5\end{array}$} & \multirow{3}{*}{$\begin{array}{c}\text { Public } \\
7 \\
6\end{array}$} & \multirow{3}{*}{$\begin{array}{c}\text { Total } \\
4 \\
4\end{array}$} & \multirow{3}{*}{$\begin{array}{c}\text { Public } \\
4 \\
3\end{array}$} \\
\hline Teachers who teach basic computer skills (or & MF & & & & & & \\
\hline computing) & $\mathbf{F}$ & & & & & & \\
\hline \multirow{2}{*}{$\begin{array}{l}\text { Teachers currently teaching subject(s) using ICT } \\
\text { facilities }\end{array}$} & MF & 43 & 69 & 68 & 100 & 100 & 100 \\
\hline & $\mathbf{F}$ & $\ldots$ & $\ldots$ & $\ldots$ & $\ldots$ & $\ldots$ & $\ldots$ \\
\hline \multirow{2}{*}{$\begin{array}{l}\text { Teachers trained to teach basic computer skills } \\
\text { (or computing) }\end{array}$} & MF & 4 & 5 & 6 & 7 & 4 & 4 \\
\hline & $\mathbf{F}$ & 4 & 5 & 5 & 6 & 4 & 3 \\
\hline \multirow{2}{*}{$\begin{array}{l}\text { Teachers trained to teach subject(s) using ICT } \\
\text { facilities }\end{array}$} & MF & 43 & 69 & 68 & 100 & 100 & 100 \\
\hline & $\mathbf{F}$ & $\ldots$ & $\ldots$ & $\ldots$ & $\ldots$ & $\ldots$ & $\ldots$ \\
\hline \multirow{2}{*}{$\begin{array}{l}\text { Teachers trained via ICT-enabled distance } \\
\text { education programmes }\end{array}$} & MF & . & . & . & . & $\cdot$ & $\cdot$ \\
\hline & $\mathbf{F}$ & . & . & . & . & . & . \\
\hline
\end{tabular}

Notes:

Learners to computer connected to the Internet ratio (LCCIR) may include computers for administrative, community and pedagogical use, therefore, indicator may overestimate access to computers

category not applicable

missing or not available (also identified as $m$ )

- value nil or negligible

** UIS estimates

Further information regarding data used in this country profile, including indicator definitions and data sources is available upon demand. Information on indicator definitions is also available at: http://www.uis.unesco.org/Library/Documents/ICT_Guide_EN_v19_reprintwc.pdf

Information and Communication Statistic

(c) UNESCO Institute for Statistics, 2012 


\section{Annex II}

\section{Questionnaire on Statistics of Information and Communication Technologies (ICT) in Education}

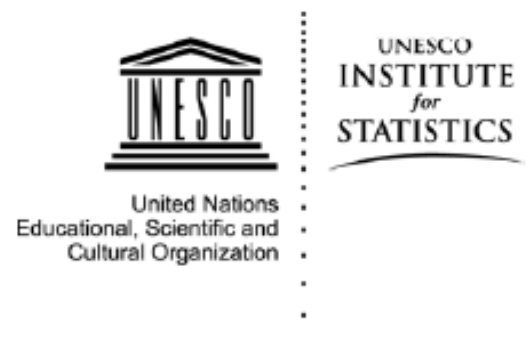

UISICIEDIICT/2011
Montreal, July 2010
Country.

\section{QUESTIONNAIRE ON STATISTICS OF INFORMATION AND COMMUNICATION TECHNOLOGIES (ICT) IN EDUCATION}

\section{Academic year ending 2010 or latest year available}

This questionnaire is designed to collect recent statistics in order to produce policy relevant indicators on key aspects of ICT integration in education. The data will be published in the UNESCO Institute for Statistics (UIS) Data Centre at http://stats.uis.unesco.org and major international reports.

Please return the completed questionnaire before $28^{\text {th }}$ March 2011. The electronic form can be submitted directly to the UIS by email to b.valdez-melgar@unesco.org. Questionnaires completed using the printed forms should be sent to:

UNESCO Institute for Statistics

P.O. Box 6128 , Succursale Centre-Ville

Montreal, Quebec H3C 3J7

Canada

Telephone: (1 514) 343-7392

Fax: $\quad(1514) 343-6872$

Please refer to the Glossary before completing the questionnaire.

Data reported in this questionnaire should cover all educational institutions in your country. If this is not the case, please provide a detailed explanation using a comment in the electronic form or footnote in the printed form. To enter comments in the electronic form, please press the RIGHT mouse button and click on "Insert comments".

Please do not leave any cell blank. Please use the following symbols in the tables if you do not have the data requested:

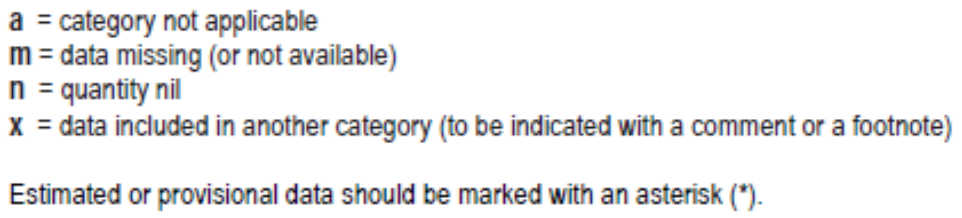




\section{RESPONDENT INFORMATION}

Please provide details below of the person responsible for completing this questionnaire.

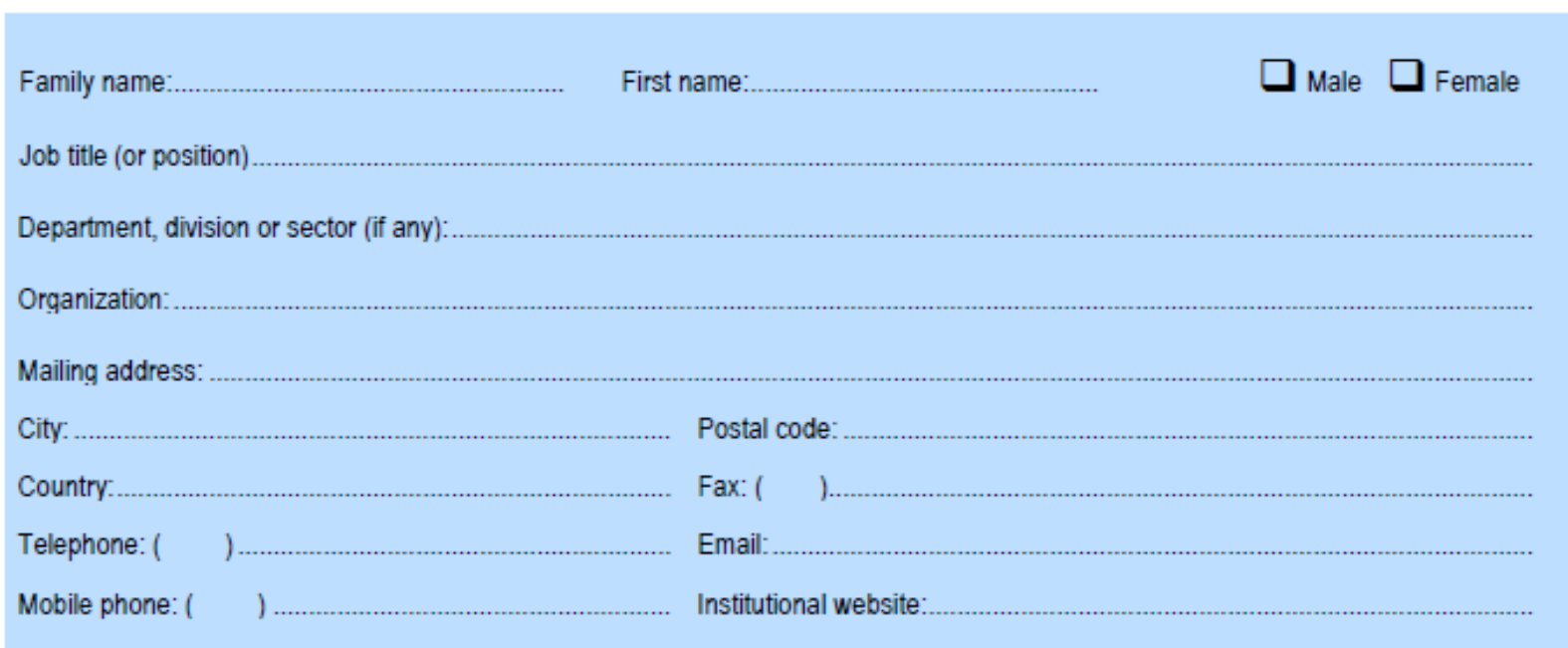

\section{REFERENCE YEAR FOR THE DATA SUBMITTED IN THE QUESTIONNAIRE}

Data reported in this questionnaire should refer to the academic year ending in 2010. If data are not available for the requested year, please report the most recent year available.

The academic year began in (month) $20 \ldots \ldots$

and ended in (month) 20....... 


\section{Continued}

\section{SECTION A: POLICY AND CURRICULUM}

Please provide the source of the data reported in Section A, if different from the main source on the second page:

\section{Organization:}

Department:

Data source (name of publication, database, website, etc.):

A.1 In order to promote/implement the integration of ICT in Education, does your country have ....?

\begin{tabular}{|c|c|c|c|c|c|c|c|}
\hline & & \multicolumn{2}{|c|}{ ISCED 1} & \multicolumn{2}{|c|}{ ISCED 2} & \multicolumn{2}{|c|}{ ISCED 3} \\
\hline A.1.1 & a national policy? & $\boldsymbol{D}_{\text {Yes }}$ & $\boldsymbol{D}_{\mathrm{No}}$ & $D_{Y e s}$ & D No & $\boldsymbol{D}_{\text {Yes }}$ & $\boldsymbol{D}_{\mathrm{No}}$ \\
\hline A.1.2 & a national plan? & $\boldsymbol{D}_{\mathrm{Yes}}$ & $a_{\mathrm{No}}$ & $\nabla_{\text {Yes }}$ & $\square_{\text {No }}$ & $\boldsymbol{D}_{\mathrm{Yes}}$ & $a_{\mathrm{No}}$ \\
\hline A.1.3 & a set of regulatory provisions? & $\nabla_{\text {Yes }}$ & $\boldsymbol{D}_{\mathrm{No}}$ & $\nabla_{\mathrm{Yes}}$ & D No & $\square_{\text {Yes }}$ & $\square_{\mathrm{No}}$ \\
\hline A.1.4 & a regulatory institution or body? & $\boldsymbol{D}_{\text {Yes }}$ & $\boldsymbol{D}_{\mathrm{No}}$ & $D_{\mathrm{Yes}}$ & D No & $\boldsymbol{D}_{\text {Yes }}$ & $\boldsymbol{D}_{\mathrm{No}}$ \\
\hline
\end{tabular}

A.2 Does your country have a national policy specifically for the use of open educational resources?

$\square$ Yes $\square$ No

A.3 Does your curriculum include specific objectives or a subject on basic computer skills (or computing)?

\begin{tabular}{|c|c|c|}
\hline ISCED 1 & ISCED 2 & ISCED 3 \\
\hline$\square_{\text {Yes }} \square$ No & $\square_{Y e s} \square_{\text {No }}$ & $\square_{\text {Yes }}$ \\
\hline
\end{tabular}

A.4 As part of the policies/plans/provisions to integrate ICT in education, are there recommendions for ICT-assisted instruction to form part of subject delivery at specific grade(s)?

$\square$ Yes $\square$ No

If the answer to Question A.4 is yes, please tick all applicable boxes that have ICT-assisted instruction by subject.

\begin{tabular}{l|l|c|c|c|c|c|c|}
\cline { 3 - 7 } \multicolumn{2}{c|}{} & \multicolumn{2}{c|}{ ISCED 1 } & \multicolumn{2}{c|}{ ISCED 2 } & \multicolumn{2}{c|}{ ISCED 3 } \\
\cline { 3 - 8 } \multicolumn{2}{c|}{} & Every grade & $\begin{array}{c}\text { At least one } \\
\text { grade }\end{array}$ & $\begin{array}{c}\text { Every grade } \\
\text { A.4.1 }\end{array}$ & $\begin{array}{c}\text { At least one } \\
\text { grade }\end{array}$ & Every grade & $\begin{array}{c}\text { At least one } \\
\text { grade }\end{array}$ \\
\hline A.4.2 & Mathematics & $\square$ & $\square$ & $\square$ & $\square$ & $\square$ & $\square$ \\
\hline A.4.3 & Sciences & $\square$ & $\square$ & $\square$ & $\square$ & $\square$ & $\square$ \\
\hline A.4.4 & Basic computer skills (or computing) & $\square$ & $\square$ & $\square$ & $\square$ & $\square$ & $\square$ \\
\hline A.4.5 & Written communication (language) & $\square$ & $\square$ & $\square$ & $\square$ & $\square$ & $\square$ \\
\hline A.4.6 & Second language & $\square$ & $\square$ & $\square$ & $\square$ & $\square$ & $\square$ \\
\hline A.4.7 & Arts & $\square$ & $\square$ & $\square$ & $\square$ & $\square$ & $\square$ \\
\hline
\end{tabular}




\section{Continued}

A.5 Please indicate the total statutory annual instructional time (in hours) for the following ISCED levels:

\begin{tabular}{|c|c|c|c|c|}
\hline & \multicolumn{3}{|c|}{ Recommended statutory annual instructional hours - cumulative hours for all grades by level } \\
\hline & & ISCED 1 & ISCED 2 & ISCED 3 \\
\hline A.5.1 & All subjects (Total) & & & \\
\hline A. 5.2 & ICT-assisted instruction & & & \\
\hline A. 5.3 & Computer-assisted instruction & & & \\
\hline
\end{tabular}

\section{SECTION B: EDUCATIONAL PROGRAMMES AND ENROLMENT}

Please provide the source of the data reported in Section B, if different from the main source on the second page:

\section{Organization:}

Department:

Data source (name of publication, database, website, etc.):

Table 1: $\quad$ Educational institutions by programme level

\section{NB. In the table below,}

- Columns (1), (2) and (3) must contain the number of educational institutions offering educational programmes at each level. Double counting is permitted since an edscational institution may offer two or more programmes that span more than one ISCED level. For example, if an educational institution offers both ISCED 2 and ISCED 3 programmes, it must be counted once under ISCED 2 and once under ISCED 3)

- Column (4) refers only to educational institutions as organisational units regardless of the number of ISCED1-3 programmes they offer. Therefore, (4) is NOI the total of columns (1), (2) and (3).

- B.1 is NOT the sum of B.1.1 to B.1.9

\begin{tabular}{|c|c|c|c|c|c|c|c|c|c|}
\hline & \multicolumn{8}{|c|}{ Primary and secondary (ISCED 1,2 and 3) - All programmes } \\
\hline & & \multicolumn{2}{|c|}{$\begin{array}{c}\text { (1) } \\
\text { ISCED } 1\end{array}$} & \multicolumn{2}{|c|}{$\begin{array}{l}(2) \\
\text { ISCED } 2\end{array}$} & \multicolumn{2}{|c|}{$\begin{array}{c}\text { (3) } \\
\text { ISCED 3 }\end{array}$} & \multicolumn{2}{|c|}{ ISCED 1,2 and 3} \\
\hline & & Total & $\begin{array}{l}\text { Of which: } \\
\text { Public }\end{array}$ & Total & $\begin{array}{l}\text { Of which: } \\
\text { Pubic }\end{array}$ & Total & $\begin{array}{l}\text { Of which: } \\
\text { Public }\end{array}$ & $\begin{array}{c}\text { Total } \\
\text { (Orqanisational } \\
\text { units) }\end{array}$ & $\begin{array}{c}\text { Of whicn: } \\
\text { Puolic } \\
\text { (Organisational } \\
\text { units) } \\
\end{array}$ \\
\hline B.1 & Number of educational institutions & & & & & & & & \\
\hline B.1.1 & $\begin{array}{l}\text { Number of educational institutions } \\
\text { wth electricity }\end{array}$ & & & & & & & & \\
\hline B.1.2 & $\begin{array}{l}\text { Number of educational institutions } \\
\text { with a telephone communication } \\
\text { facility }\end{array}$ & & & & & & & & \\
\hline B.1.3 & $\begin{array}{l}\text { Number of educational institutions } \\
\text { with radio-assisted instruction }\end{array}$ & & & & & & & & \\
\hline B.1.4 & $\begin{array}{l}\text { Number of educational institutions } \\
\text { with television-assisted instruction }\end{array}$ & & & & & & & & \\
\hline B.1.5 & $\begin{array}{l}\text { Number of educational institutions } \\
\text { with computer-assisted instruction }\end{array}$ & & & & & & & & \\
\hline B.1.5.1 & $\begin{array}{l}\text { Number of educational } \\
\text { institutions with computer } \\
\text { laboratories }\end{array}$ & & & & & & & & \\
\hline B.1.5.2 & 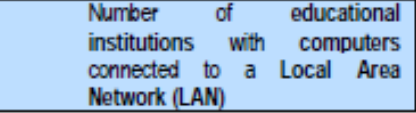 & & & & & & & & \\
\hline
\end{tabular}




\begin{tabular}{|c|c|c|c|c|c|c|c|c|c|}
\hline & & \multicolumn{8}{|c|}{ Primary and secondary (ISCED 1,2 and 3) - All programmes } \\
\hline & & \multicolumn{2}{|c|}{$\begin{array}{c}\text { (1) } \\
\text { ISCED } 1\end{array}$} & \multicolumn{2}{|c|}{$\begin{array}{c}(2) \\
\text { ISCED } 2 \\
\end{array}$} & \multicolumn{2}{|c|}{$\begin{array}{c}\text { (3) } \\
\text { ISCED } 3\end{array}$} & \multicolumn{2}{|c|}{$\begin{array}{l}(4) \\
\text { ISCED } 1,2 \text { and } 3\end{array}$} \\
\hline & & Total & $\begin{array}{l}\text { Of which: } \\
\text { Public }\end{array}$ & Total & $\begin{array}{l}\text { Of which: } \\
\text { Pubic }\end{array}$ & Total & $\begin{array}{l}\text { Of which: } \\
\text { Public }\end{array}$ & $\begin{array}{c}\text { Total } \\
\text { (Onganisational } \\
\text { units) }\end{array}$ & $\begin{array}{l}\text { Of which: } \\
\text { Pubic: } \\
\text { (Orgarisational } \\
\text { units) }\end{array}$ \\
\hline B.1.6 & $\begin{array}{l}\text { Number of educational institutions } \\
\text { wth access to the Internet }\end{array}$ & & & & & & & & \\
\hline B.1.6.1 & $\begin{array}{l}\text { Number of educational } \\
\text { institutions with fixed broadband } \\
\text { Internet }\end{array}$ & & & & & & & & \\
\hline B.1.6.2 & $\begin{array}{l}\text { Number of educational } \\
\text { institutions with Internet-assisted } \\
\text { instruction }\end{array}$ & & & & & & & & \\
\hline B.1.7 & $\begin{array}{l}\text { Number of educational institutions } \\
\text { wth open educational resources }\end{array}$ & & & & & & & & \\
\hline B.1.8 & $\begin{array}{l}\text { Number of educational institutions } \\
\text { wth ICT support services }\end{array}$ & & & & & & & & \\
\hline B.1.9 & $\begin{array}{l}\text { Number of educational institutions } \\
\text { wth a website }\end{array}$ & & & & & & & & \\
\hline
\end{tabular}

Table 2: Enrolment by gender and ISCED level

\section{NB. In the table below, \\ - $\quad M F^{\prime}$ refers to both sexes and ' $F$ ' refers to female. \\ - B.2 is NOT the sum of B.2.1 to B.2.8}

\begin{tabular}{|c|c|c|c|c|c|c|c|c|}
\hline & & & & & & \\
\hline & & & \multicolumn{6}{|c|}{ Primary and secondary pupils - All programmes } \\
\hline & & & \multicolumn{2}{|c|}{ ISCED 1} & \multicolumn{2}{|c|}{ ISCED 2} & \multicolumn{2}{|c|}{ ISCED 3} \\
\hline & & & Total pupis & Of which: Public & Total pupils & Of which: Public & Total pupils & Of which: Public \\
\hline \multirow{2}{*}{ B.2 } & \multirow{2}{*}{ Enrolment } & MF & & & & & & \\
\hline & & $F$ & & & & & & \\
\hline \multirow{2}{*}{ B.2.1 } & \multirow{2}{*}{$\begin{array}{l}\text { Enrolment in proqrammes } \\
\text { having access to electricity }\end{array}$} & MF & & & & & & \\
\hline & & $F$ & & & & & & \\
\hline \multirow{2}{*}{ B.2.2 } & \multirow{2}{*}{$\begin{array}{l}\text { Enrolment in programmes } \\
\text { having access to telephone } \\
\text { communication facility }\end{array}$} & MF & & & & & & \\
\hline & & $F$ & & & & & & \\
\hline \multirow{2}{*}{ B.2.3 } & \multirow{2}{*}{$\begin{array}{l}\text { Enrolment in programmes } \\
\text { offering radio-assisted } \\
\text { instruction }\end{array}$} & MF & & & & & & \\
\hline & & $\mathrm{F}$ & & & & & & \\
\hline \multirow{2}{*}{ B.2.4 } & \multirow{2}{*}{$\begin{array}{l}\text { Enrolment in programmes } \\
\text { offering television-assisted } \\
\text { instruction }\end{array}$} & MF & & & & & & \\
\hline & & $F$ & & & & & & \\
\hline \multirow{2}{*}{ B.2.5 } & \multirow{2}{*}{$\begin{array}{l}\text { Enrolment in programmes } \\
\text { offering computer-assisted } \\
\text { instruction }\end{array}$} & MF & & & & & & \\
\hline & & $F$ & & & & & & \\
\hline \multirow{2}{*}{ B.2.6 } & \multirow{2}{*}{$\begin{array}{l}\text { Enrolment in programmes } \\
\text { offering Internet-assisted } \\
\text { instruction }\end{array}$} & MF & & & & & & \\
\hline & & $\mathrm{F}$ & & & & & & \\
\hline \multirow{2}{*}{ B.2.7 } & \multirow{2}{*}{$\begin{array}{l}\text { Enrolment in programmes } \\
\text { having access to open } \\
\text { educational resources }\end{array}$} & MF & & & & & & \\
\hline & & $\mathrm{F}$ & & & & & & \\
\hline \multirow{2}{*}{ B.2.8 } & \multirow{2}{*}{$\begin{array}{l}\text { Enrolment in courses } \\
\text { offering basic computer skills } \\
\text { (or computing) }\end{array}$} & MF & & & & & & \\
\hline & & $\mathrm{F}$ & & & & & & \\
\hline
\end{tabular}




\section{Continued}

Table 3: $\quad$ Enrolment $(t-1)$ in the previous school year by gender and ISCED level

\section{NB. In the table below,}

- 'MF' refers to both sexes and 'F' refers to female.

\begin{tabular}{|c|c|c|c|c|c|c|c|c|}
\hline & & & \multicolumn{6}{|c|}{ Primary and secondary pupils - All programmes } \\
\hline & & & \multicolumn{2}{|c|}{ ISCED 1} & \multicolumn{2}{|c|}{ ISCED 2} & \multicolumn{2}{|c|}{ ISCED 3} \\
\hline & & & Total pupis & Of which: Public & Total pupils & Of which: Public & Total pupils & Of which: Public \\
\hline \multirow{2}{*}{ B.3 } & \multirow{2}{*}{ Enrolment $(t-1)$} & MF & & & & & & \\
\hline & & $\mathrm{F}$ & & & & & & \\
\hline \multirow{2}{*}{ B.3.1 } & \multirow{2}{*}{$\begin{array}{l}\begin{array}{l}\text { Enrolment in programmes } \\
\text { offering computer-assisted } \\
\text { instruction }(t-t)\end{array} \\
\end{array}$} & MF & & & & & & \\
\hline & & $\mathrm{F}$ & & & & & & \\
\hline \multirow{2}{*}{ B.4 } & \multirow{2}{*}{ Pupils who passed at the end of $t-1$} & MF & & & & & & \\
\hline & & $\mathrm{F}$ & & & & & & \\
\hline \multirow{2}{*}{ B.4.1 } & \multirow{2}{*}{$\begin{array}{l}\text { Pupils who passed at the end of } \\
t-1 \text { from programmes offering } \\
\text { computer-assisted instruction }\end{array}$} & MF & & & & & & \\
\hline & & $\mathrm{F}$ & & & & & & \\
\hline
\end{tabular}

\section{SECTION C: COMPUTERS}

Please provide the source of the data reported in Section C, if different from the main source on the second page:

\section{Organization:}

Department:

Data source (name of publication, database, website, etc.):

Table 4: $\quad$ Computers allocated to educational programmes

\section{NB. In the table below,}

- Columns (1), (2) and (3) must contain the number of available computers at each level whether they are shared or not across levels. Therefore, double courting is permitted

- Column (4) refers only to the available number of computers (physical units) in all primary and secondary programmes. (4) is NOT the total of columns (1), (2) and (3).

- C.3 is NOT the sum of C.3.1 to C.3.4

\begin{tabular}{|c|c|c|c|c|c|c|c|c|c|}
\hline & & \multicolumn{8}{|c|}{ Primary and secondary (ISCED 1,2 and 3) - All programmes } \\
\hline & & \multicolumn{2}{|c|}{$\begin{array}{c}\text { (1) } \\
\text { ISCED } 1\end{array}$} & \multicolumn{2}{|c|}{$\begin{array}{c}\text { (2) } \\
\text { ISCED } 2 \\
\end{array}$} & \multicolumn{2}{|c|}{$\begin{array}{c}\text { (3) } \\
\text { ISCED } 3 \\
\end{array}$} & \multicolumn{2}{|c|}{$\begin{array}{c}(4) \\
\text { ISCED } 1,2 \text { and } 3\end{array}$} \\
\hline & & Total & $\begin{array}{l}\text { Of which: } \\
\text { Public }\end{array}$ & Total & $\begin{array}{l}\text { Of which: } \\
\text { Pubic }\end{array}$ & Total & $\begin{array}{l}\text { Of which: } \\
\text { Public }\end{array}$ & $\begin{array}{c}\text { Total } \\
\text { (Physical units) }\end{array}$ & $\begin{array}{c}\text { Of which: } \\
\text { Public } \\
\text { (Physical units) }\end{array}$ \\
\hline C.3 & Number of computers available & & & & & & & & \\
\hline C.3.1 & $\begin{array}{l}\text { Number of computers for } \\
\text { pedagogical use }\end{array}$ & & & & & & & & \\
\hline C.3.2 & $\begin{array}{l}\text { Number of computers for } \\
\text { administrative use }\end{array}$ & & & & & & & & \\
\hline C.3.3 & $\begin{array}{l}\text { Number of computers for } \\
\text { community use }\end{array}$ & & & & & & & & \\
\hline C.3.4 & $\begin{array}{l}\text { Number of computers connected } \\
\text { to the Internet }\end{array}$ & & & & & & & & \\
\hline
\end{tabular}




\section{SECTION D: PRIMARY AND SECONDARY TEACHERS}

Please provide the source of the data reported in Section D, if different from the main source on the second page:

Organization: .

Department:

Data source (name of publication, database, website, etc.):

Table 5: $\quad$ Teaching staff by gender and ISCED level

\section{NB. In the table below, \\ - $M F^{\prime}$ 'refers to both sexes and ' $F$ ' refers to female. \\ - D. 1 is NOT the sum of D.1.1 to D.1.5}

\begin{tabular}{|c|c|c|c|c|c|c|c|c|}
\hline & & & \multicolumn{6}{|c|}{ Primary and secondary - All programmes - Part-ime and ful-time teachers (Headcounts) } \\
\hline & & & \multicolumn{2}{|c|}{ ISCED 1} & \multicolumn{2}{|c|}{ ISCED 2} & \multicolumn{2}{|c|}{ ISCED 3} \\
\hline & & & Total & $\begin{array}{l}\text { Of which: } \\
\text { Public }\end{array}$ & Total & $\begin{array}{l}\text { Of which: } \\
\text { Public }\end{array}$ & Total & $\begin{array}{l}\text { Of which: } \\
\text { Public }\end{array}$ \\
\hline \multirow{2}{*}{ D.1 } & \multirow{2}{*}{ Number of teachers } & MF & & & & & & \\
\hline & & $F$ & & & & & & \\
\hline \multirow{2}{*}{ D.1.1 } & \multirow{2}{*}{$\begin{array}{l}\text { Number of teachers who teach basic } \\
\text { computer skills (or computing) }\end{array}$} & MF & & & & & & \\
\hline & & $\mathrm{F}$ & & & & & & \\
\hline \multirow{2}{*}{ D.1.2 } & \multirow{2}{*}{$\begin{array}{l}\text { Number of teachers currently teaching } \\
\text { subject(s) using ICT facilities }\end{array}$} & MF & & & & & & \\
\hline & & $F$ & & & & & & \\
\hline \multirow{2}{*}{ D.1.3 } & \multirow{2}{*}{$\begin{array}{l}\text { Number of teachers trained via ICT-enabled } \\
\text { distance education programmes }\end{array}$} & MF & & & & & & \\
\hline & & $F$ & & & & & & \\
\hline \multirow{2}{*}{ D.1.4 } & \multirow{2}{*}{$\begin{array}{l}\text { Number of teachers trained to teach basic } \\
\text { computer skills (or computing) }\end{array}$} & MF & & & & & & \\
\hline & & $F$ & & & & & & \\
\hline \multirow{2}{*}{ D.1.5 } & \multirow{2}{*}{$\begin{array}{l}\text { Number of teachers trained to teach } \\
\text { subject(s) using ICT facilities }\end{array}$} & MF & & & & & & \\
\hline & & $F$ & & & & & & \\
\hline
\end{tabular}




\section{GLOSSARY}

\section{ALL PROGRAMMES}

All proqremmes include both qeneral education as well as techrical and vocationsl ebucation srogrammes. See conresponding definitions.

\section{ANNUAL INSTRUCTIONAL TIME}

Annual instuctional time (in hours) conesponds to the tolsl number of statubay hours that se allocated for leaming activites in a school year acconding to the nebional regulations. That is to say, these sere the intended number of hours expected to be used for educabonal activites in a given school year for a given grade.

Please note that instivctionsl periods must comespond to a full hour equivalent of 60 minutes. Where the siandard duretion of a period is different form 60 minutes, it is transfomed int a ful hour equivilent by dividing by 60 minutes.

Armualinstructonal time (n) hours) is calculated as.

Stan dart duration of a period in minutes / 60 minutes "nuntos of instuctuonal periocts in a day" " phet nuntor of instructional days per annum)

Where $n$ a number of instructional days per annum is equivalent to the rimbg of

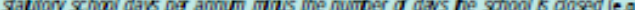
festivites, national holidsys, nonfeaching pedagogical days, eic.)

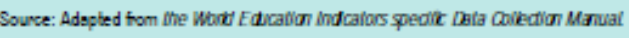

\section{BASIC COMPUTER SKILLS}

Basic computer skils is a curriculum module that covers the most common usages of a compute; inchuding a majonity or al of the folowinq: understending the basic nobions of computer manipulation; managing compuler fles, word processing, using spresdsheets and daisbases; creatina oresentesions; findina infommation and communicasing using computers; and being swave of social and ethical implications of Intemet use.

From a statabical perspective, nationaly-defined content of such modules should be considered. In the absence of a rationsl standand, plesse consider cumiculum modules that have a majority or al of the above content units as equivalent to a basic computer skils course.

Bosic comsuter gkils mar be tought as a seporate subiect or inteqraied into other subiects. A common standasd applied by a qvowing number of countries is the Intemstonsl Computer Driving

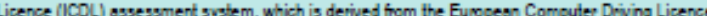
(ECDL)

\section{COMPUTER}

Computer refens to a proqrammable electronic device that can store, retieve and process data, as wel as share information in a highly-stuctured manner. It pefomms high-speed mathemofical of logical opesafons scconding to a set of instructions.

When providing dabs on the number of computers, sersonal compulers [PCs], lapioss, noitebooks, temminals comected to meinframes and mini-computers intended for shared use should be included. Comouters must also be of functonal use to meet pedopoqical andlor sdministrefive needs.

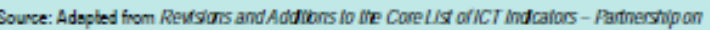
Measuntig ICT io Deviqumert.

\section{COAPUTER-ASSISTED INSTRUCTION}

Computer-assisted instuction is an intersctive lesming method in which a compuler is used by teachers andlor supils to sresent instrucfonal materal, to perform tasks for lesernina and to help in selecting and sccessing sbdiffonal pedogogical matenial.

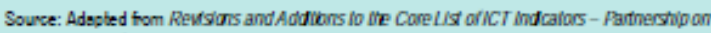
Measuitig ICT í Deviqumert

\section{COMPUTER LABORATORY}

Computer laboratory is a room or space equipped with computers (networked or not) devoted to pedsgogical use in an educsbional instution.

A combuter laborstory must be safe from any disnuptive, non-sedsqoqical conient where pusils ond teachers mar need subhorized occess credentals. In this cortext, Initemet booth lor community Iniemet centes] must be ercluded unless there is a deciove policy bo use such facilites for pedagogical purposes.

\section{COMPUTERS FOR ADMNISTRATIVE USE}

Computers for adminighetive use refer to compulers used by non-tesching siaff to sssist w th school manspement Such ussqe may include record-keeping or date processing and anablyis of regisbation and daily attendance in classes, tesching and non-lesching staff, physical schoo faciltes, busqet and expendhure data, and assessment resuls. Ft also includes planning of programmes and deployment of humsn, materisl and financial resouvces. It may involve secreiario usaqe frough word processina, es wel as communications with extemal bodes or parents through emeils.

\section{COMPUTERS FOR PEDAGOGICAL USE}

Compules for sedsqoqical use refers to the use of comsuters to support course delivery or independert teschina and lesmina needs. This moy include activites using computers or the Intemet to meet infomation needs for research purposes; develop presentafions; perform handson exercises and experiments, share irfomafon, and saticisate in orline decussion forums for stucational purposes.

\section{COMPUTING}

Compufina refers to a course proqramme usualy tought st ISCED 4,5 or 6 levels. Some schools may also isech compuling (mainly computer progresmming) at ISCED 3. Typical compuling course

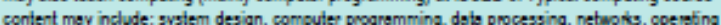
systems and sofiware development. Computing does not include computer hardware design, construction and production.

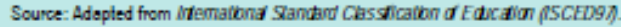

\section{COURSE}

A course is a planned series of leaming experiences in a portioular subject matter or set of skils, usually offered by an educesional or treining insthution or progremme for one or more pupils.

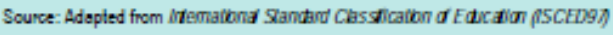

\section{CURBICULUM}

Currioulum refers to the design, planning and sequencing of tesching and leaming processes. It includes o statement of purpose, cortents, octivites and lesmina srectices, as wel as the moda ites for assessing pusis achevements. For the pursose of this questonnaire, the relevart subiects that sec contained in the cumiculum sve defined below:

Mathematt: mathematics, mathematics with sistisfics, geomety. Sdence: science, physics, shysical science, chemistry, bioloqy, human biology, onvironmental gcience, sgriculure / horfoulture / foresily.

Bastc computer stills (compulung: See comesponding definitions Wrilen communicaton (Aanquage). This refers to reading and wribing in the benque of ingtuction nomslly used in educationsl progermmes.

Second language: This refers to reading ond wrting in a second 'fongue' (eg., a foreign lanquage) or reasing and wrting in the native bongue of the courtry as a second language (for non natives).

Art: arts, music, visusl ats, practical art, drams, perfomance music, pholography. drewing, creabie handicrat, creative need lework.

\section{EDUCATIONAL INSTITUTIONS}

Educatonal insflufions have as their sole or main puppose the provision of esucsion. Such

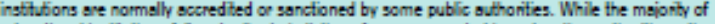
stucational institutions fall under the junisdiction of, or are operated by, education suthontes, other public sqencies deslinq with such aress ss healh, baininq, lebour, iustice, defence, socid sevices, etc. may also be involved. Educationsl instifutions may slso be opersted by private ongerizotions such as religious bodies, special-interest groups or privete educationsl and training institubions, both profit and non-proft making.

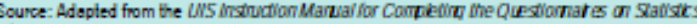
or Educaion -2003 .

\section{ELECTRICITY}

Electricky refers to requiarty and readly avalable souvces of power (e.q. qrid mains cornection, wind, water, solar and fuelpowe red generebor, elc.) that ensble the sdeguate and sustainable use of ICT infrsatucture for educetionsl purposes.

In this questionnaie, envolment in educebional swoqremmes offered by instiufions heving sccess is electricity must be courited

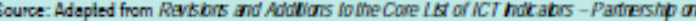
Moasung ICT for Devebpiment

\section{ENROLMENT (OR ENROLED)}

Ennolment (or ennoled) refers to a pusil registered in a grobe or progremme of study at an sobucational institution who met enrolment prerequisties at the registration dats.

Period (i) refers to enrolment for the school year ending in 2010 or most recent year svalable. Period $(k-1)$ refers to enrolment for the preceding school yest ending in 2009 . 


\section{FDED BROADBAND NTERNET}

Fixed broodbend Iniemet refers to high-speed comectivity for public use of at least $256 \mathrm{Kbits}$ o more in one or both drections (bownloading and uplosding). It incluses cable modem Intemei connections, DSL. Inisenet connections of at least $256 \mathrm{Kbits}$ or hiqher, fbre and other fxed broosbend technoloqy connections (such as sotelithe brosdband Intemet, Ehemet LANs, fxed wireless sccess, Wireless Local Ares Network, WMUAX, eic.)

Privaite intemet connectivity within educationsl ingtiubions vis mobile phone networks is exduded.

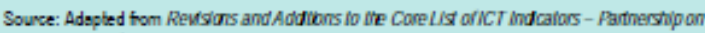
ueasuriti ICT is Devaqumert.

\section{GENERAL PROGRAMMES}

General programmes (or general education) are designed meinly to provide pupils with a deepe; undergtendina of a subiest or qroup of subjects, especially - but not necesserily - with 8 view to orepsing pupis for further education at the some or higher level. Such programmes are typically school-based and may or may not contain vocationsl elements. Successul completion of such scogrammes may lesd bo an academic qualfication. However, successful completers bypically connot enter s sarticular occusation, tesde or class of occupe jors or trades w thout furthe? baining. Programmes w th a general orientabion and not focused on a particules specializabon should be classfied in this caiegory.

\section{ICT FACILIIES}

See defintion of aromaibon and Comminicalion Teinobges (NCT).

\section{ICT SUPPORT SERVICES}

ICT supsort sevices refer to a renge of sevices implemerted by educational insthutions in onder to ensure pemsnence and pefformance of focilties for operating ICT-assisied instruction w thout discontinuty. The implementation of such services may imply opersional of administrative messures to support the sustainability of ICT-sssisted operations by sasigning a desigraited unit or staf member to the task or qrenting renewable quarterly, biquartaly or vesty contrectis) to private service provider(s). Key objectues behind the use of ICT suppot services by schools may include:

- ascetsining thot every pedsgogic and adminibbstive unit, including specisl needs and larary units, identifes its requirements foe ICT spovision.

- Coondinebing the effective use of ICT accoss the whole curriculum and encouraping sspects of enoss-curriculer planning:

- helping pedogogic and sdministrative units to consider how ICT can support the teaching and lesring of subjects other then computing and what those subjects can corbbbute to the tesching and leamina of ICT aklls;

- monitoring on behalf of the serior leadership team how equipment and soffwave are monitoming on benaff of the senior lessership team how equpment snd seftware are accommodated, acquired, mased by pupls and siaf,

- ensuring that sensible, tersosorent decigions are mode where there are compeling demands for resources and that the school improvement plan includes plans for encoursaing and supporina the socfessional develosment of al staff in the use of ICT in their subjects, in line with school policy and prectices; and

- managing the school's ICT technician and network maroger, etc.

From a sististical perspective, inespective of the modslibes for scauining such services ether through one or multiple means, the sole existence of such reguler of renewable conbseded services in an educsfonsl institubion imples the presence of ICT support services.

Souve: Adspled from the Department for Chidven, Schools and Famites.

\section{ICT-ASSSTED INSTRUCTION}

CT-assisied instuction refers to teaching methods or models of instuction defivery that employ

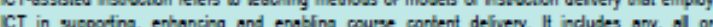
ICT in susportina, enhancing and enabina course cortent delivery. It includes any,
combinations of the following: rodio, television-, computer and linternetossisted insivuction.

\section{ICT-ENAELED DISTANICE EDUCATION PROGRAMMES}

ICT-ensbled distance sducation proqrammes refer to provrsmmes or instuctionsl systems that use ICT Intemet, rodio sebs, television sets, sersonsl comsuters, sudiovisual material of print maierial to a minimal deqree] to deliver al or a signficant portion of tesching to pupis removed in spoce and bime. Distance educabion can taks a variety of forms, which include:

- Intemet-bosed diatance learning either synchnonously or asynchronously,

- Telecourse or broodcast-based educsion, in which cortent is delivered vis radio or Telecourse
television;

- CD-ROM or DVD-besed seffleserning in which the pupils intersets with computer content

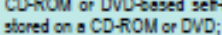

- Mobile devices-besed learning where the leamer accesses course content stored on o mobile device or through a wireless sever, and

- Integrated distance lesmina, combining live verens reconded delivery modes, individualzed interection versus group instruction through verious channels, andior print materials to e minimal deoves, eth

but excluse:

- Conespondence-based distance learning conducled erclusively through postahmsi.

\section{INF ORMATION AND COMMUNICATION TECHNOLOGIES (CCT)}

Foe the pupose of statstical reportina, infommation and commurication technoloqies (ICT) is defined as a diverse set of iechnoloqical tools and resources used to bansmt, store, creste, share or erchange information. These technoloqical isols and resources inclubse computers, the Intemet or erchange inforration. These technoloqical fools and rescurces incluse compules, the Irtemet recorded brooscasting technologies (podcasing, audio and video players, and storege devices) and telephony ffued or mobile, satellte, visiolvideo-conferencing, etc.]

\section{NTERNET}

Intemet refers to wondwide interconnected networks that ensble users to share information in an intersctive fomat - refered to as hypertext - through multple wired or wireless receivers (personal computers, laptops, PDAs, Smartphones, etc.). (See slso defintions for fred nomowbend Iniemet and fixed broostand Intemet)

\section{NTERNET-ASSISTED NSTRUCTION}

Intemet-sssisted instuvtion refers to an intersctive learning method using content from the Word Wide Web for pedsgogical puposes

\section{ISCEDLEVELS}

ISCED levels are defined in the 1997 version of the Mntem INorEl Slartand Cassfraton of Edtucaibn (ISCED97) mainisined by UNESCO. Levels of education are classfied as follows:

- ISCED 0 - Pre-pimary

- ISCED 1- Pimsy or fist stape of besic education

- ISCED 2- Lower secondary or second stape of besic education

- ISCED 3- Upser secondary educsion

- ISCED 4 - Post-secondary non-terfory esucation (programmes that lie between the usper secondery and ietiary levels of education)

- ISCED 5- First stage of tetiary education (not leading disctly to an odvanced resesch Qualification

- ISCED 6- Second sisqe of tertay educafion flesding to an odvanced reseanch qualficabion)

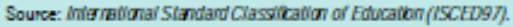

\section{LOCAL AREA NETWORK (LAN)}

A bosi ares netwok (LAN) refers to s retwork connecing compulers w thin a bcalzed sves such as a single building, department or site; it may be wireless.

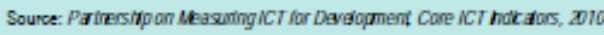

\section{OPEN EDUCATIONAL RESOURCES}

Open educational resouvces refers to electronic resources and tools for lesming in open document fomat and released under an intelectusl property licence allowing tee use, sdapistion and datibubion.

From a statistical perspective, instiufions must have a specfic policy to devcle resources for the coordination and maintenance of an electronic repository for pedagogical use.

\section{PLAN}

Plan refers to a qovemmentissued document on how its qoals are to be achieved within : specifed bimeframe. I detaly each acfivity to be undertaken, the method employed for implementabion, the resouxces required and the actors responsible for implementing each octivity.

\section{POLCY}

Policy refers to a set of ideas that has been squed officilly by a qroup of people, a businez: ongenizabion, a govemment or a polícal party usually expressed in a govemnentissued document which oudnes the pinciples, quidelines and streteay in relotion to a particulgr (oo determined) public activit.

\section{PRIVATE EDUCATION}

Private education is offered by educafonal insthutions that are contolled or manoped by a noogovemmental onganzation (including but not imited to a chuvch, trade union of busines: erterprise), whether or not 7 receives firancial supsort from pubic subhorifes.

Source: Adsoted from the UiS instirion Manual br Compieing the Questionares on Slaikics af Edratoin 


\section{PROGRAMME}

Educabional proprammes are defined as a coherent set or sequence of educationsl acfuites that are designed and onganized to achieve pre-determined learning objectives or a specific set of educafonal tasks over a sustained period. Obiecfves encompass imorving knowledac, skils and competencies within any sersond, civic, social andi/or emsloyment related coniext. This it tygicaly linked to the purpose of prepering for more stuance studies and lor for an occupation or range of occusations. A common characterisbīc of educationsl proquemmes is that, uson fuffiment of learing objectives or educational tasks, complefion is recognized or certffed by the provider.

In ISCED-97, progremmes are sssigned to levels of educofon. Broody spesking, the level is related to the degree of complenty of the content of the programme.

The notion of level' of educabion, therefore, is essentialy a constuct based on the assumplion that educationsl programmes can be grouped, both nebionaly and cross-nafionaly, into an ordered series of categories broodly comesponding to the oversell knowledge, skils and capebilibes of required paricipents if they are to heve a reasonable expectation of suecessfully completing the snoqrammes in these cateqories. These catequies represent brood steps of educations? snogression from very elementery to more complex experiences with the more complex the programme, the higher the level of education.

\section{PUBuK EDUCATIOA}

Public education is offered by educationsl institutions that are conbrled or manoped by a governmental education suthonity or sgency that can be at the netionsifederal, state/provincisl or local level, imespective of the origin of ts finencial resources.

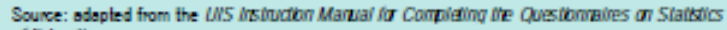
aEducation

\section{PUPILS WHO PASSED}

Pugils who passed refers to pusils who hove successfuly completed a qiven qrede in a qiven academic year $(t-t)$ and are, therefore, pemited to register in the following grode in the following academic vest (t) or "promoled" to the next arsdelevel. Nevertheless, the intertion here is not to messure the banstion or flows occoss dfferent gchool yess, but the final results of a given academic vear. A mandebory sossing mark is usually revuied for sromobion to the nert qrade. Pupils who heve possed during a recuperstion period following on academic year or session ave to Pe included.

$$
\text { PUPIL }
$$

Pupil refers to a child enroled in an educationsl programme, wheress chidren or sdults enroled at more advanced levels are students.

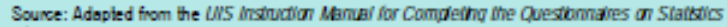
a Edcaibr.

\section{RADIO}

Ristio is congidered to be a stand-slone device (in workina condifon) capoble of receivina brosdcast radio signab, using popular frequencies (such as FM, AM, LW and SW).

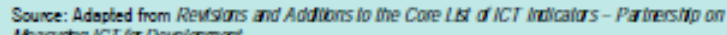
Measung NCT lit Develiqmert.

\section{RADIO-ASSISTED INSTRUCTION}

Rasio-assigted instucfon includes both redio brosdcast education and interactive redio instruction. Radio brosdcast educafon entsis an audio lecture or lesson, with pritted material for pugils to follow the lecture. Any tescher, not necessorily qualfed in the subject motite, can use the radio snoqramme as a main insivuctional souvce. Brosdcast proprammes follow the trastionsl model of educafion and can cover every subject in many diferent languoges, depending on the target educsion

Intersctive redio instruction (IFi) tums a brically one-wey technology into a tool for acfive leamina inside and outside the classvoom. It requires that pupls resct to questions and exercises through verbel responses to rofio proqremme contritubra, qroug work, and physical and intelectus: activifes while the sroqramme is on air. For both taacher and supi, the lesson becomes an immedisite hands-on proctical guide.

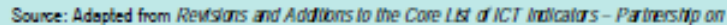
Measung ICT for Deveiqmes

\section{REGULATORY INSTITUTION}

Requlaby insthution refers to a separaie body, ongerizsion, commithee or bureau that hes been qiven responsiblity by the qovemment for promotina, coordineting and ensuring correct implemertation of lows and policies.

\section{REGULATORY PROVISION}

Requlabory provision refers to a law or leqal gnovision usually made by a qovernment, that is used to onder the wsy in which s society beheves.

\section{TEACHERS}

Teschers and tesching siaf refers to persons emoloved in an official casacity for the purpose of guiling and diecing the leaming experience of pupls, imespective of qualifcations or the delivery mechanism, is. whether face-bo-face andlor at a distance. This definbion exdudes ebucabions personnel who have no active tesching dufes (e.a. headmesiers who do not teach) or work occasionaly or in a volurtary capacity in educetional instiutions (e.g. parents).

\section{TEACHERS TRAINED TO TEACH BASIC COMPUTER SKILLS (OR COMPUTING)}

Teschers treined to teach besic compuler skils (or compuing) refers to teschers considered qualfied according to nationsl sianderts or noms to teach besic computer skils (or compuling) courges.

At hiaher ISCED levels, in partioular, teschens trained to teach computina should have a nationaly required acade rric credenfal in an ICT related field of study, such as computer science.

\section{TEACHERS TRANED TO TEACH SUBJECTS US WG ICT FACILTIES}

Teachers treined bo tesch subjects using ICT facilfes are teachers that have received at lesst a nationaly defined minimum of fombl baining to tesch one or various subjects at the relevani level(:) using ICT to support their tesching.

\section{TECHNICAL EDUCATION OK VOCATIONAL TRAINNG}

Techrical educsion or vocabional treining is desiqned mainly to provide pupils with the precticel skils, know-how and undergtandina necessay for direct enty into a partiodar occusation or trede (or class of occupsfons or trades]. Successful completion of such progremmes nommaly leads to s labour mankekrelevart vocationsl qualfication recoqnised by the nafionsl compelent suthorties (eg. Ministy of Education, employers' associations, ete.)

\section{TELEPHONE COMMUNICATION FACUITY}

Telephone communication faclity refers bo fxed teleshone lines, cable connections lie cable telephony) of other sustainable communicafon technology that cornects an educational insthibon's terminal equipment (eq. teleshone set, facsimile machine) to the public switched telephone netwok (PSTN) and has a dedicated pot on a telephone exchange. Access is defined by a subsciption to senvices that allow the physical presence and use of the faclites in a qiven educationsl instution. A mobile celular phone owned by an infvidual working ot oschool does not constihte a school iselephone communication facility.

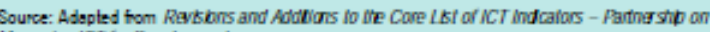
Masering ICT for Davebpanent.

\section{TELEMSION}

Television is considered to be o stand-alone device (in woking constion) casable of receivina

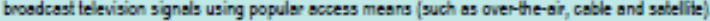

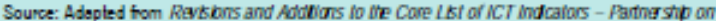
Moseuning ICT for Davebpirent.

\section{TELEVSION-ASSISTED INSTRUCTION}

Television-ossisied instruction is simis to rodio broodcast education, with the oddtional benefit of video. F helos to bring sbabset concepts to lfe through clips, snimations, simulafions, visusl effects and dremotzation. It can also conrect a classroom to the world but sheres the same riaid scheduling and lack of inierectulty ss madio brosdcast education.

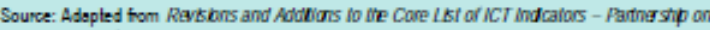
Mossuning ICT hor Daveopment.

\section{TRANED TEACHERS}

Trained teachers have received at lesst the minimum fomal tescher training (pre-service or inservice) required for teaching st the relevant level.

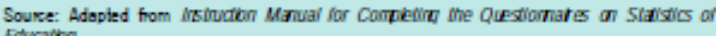
Education.

\section{WEBSTE}

Website refers to a collection of intedinked web pages with a relaied bopic, ususlly under a single domsin name. In the coniext of educational instiutions, a website indudes a home page with linis to pertinent pedsgogical information snd other related sctivites. 